\title{
CARACTERISTICAS E CLASSIFICAÇÃO DE UMA TOPOSSEQÜÉNCIA DE SOLOS DA REGIÃO DE JEQUITAÍ MINAS GERAIS
}

GIZA NARA CASTELLINI MOREIRA $\perp$

Orientador: JOSÉ LUIZ IORIATTI DEMATTE

Dissertoçōo opresentodo a Escolo
Superior de Agricultura "Luiz de
Queiroz", do Universidode de Sōo
Poulo, poro obtençóo do título
de Mestre em Solos e Nu-
triço de Plantos.

$$
\begin{gathered}
\text { PIRACICABA } \\
\text { Estodo de Söo Poulo - Brosil } \\
\text { Junho }, 1979
\end{gathered}
$$

I) Engenheiro Agrônomo, Pesquisodor do EMBRAPA 
A memória de meus pajs dedic: 
A meus sobrintos

Diego

Melissa

Juliano

e a

Abaetẽ

$\operatorname{Taz} \mathrm{s}$

Io

ofereçr. 
AGRADECIMENTOS

A autora expressa seus agradecimentos ao professor José Luiz Ioriatti Demattè, sob cuja orientação esta pesquisa foi realizada, ressaltando a dedicação, incentivo e apoio recebidos durante toda a permanéncia na Escola.

Aos professores Marcelo Nunes Camargo e Zilmar Ziller Marcos, por terem acejtado a indicação para julgar estie trabajho,

Aos professores do curso de pós-graduaçäo, pelos ensinamentos recebidos.

A EMERAPA, pela oportunidade de frequentar o curso e pelo suporte financeiro.

Aos senhores chefes do SNLCS, pesquisadores Abeilard Fermando de Castro, Clotário Olivier da Silveira e Cesar Augusto Lourenço, pelo apoio recebido.

Aos colegas do SNLCS, pesquisadores Raphael Mi notti Bloise, José Flávio Dynia e Washington de oliveira Bar- 
reto, pelas sugestões apresentadas.

Aos colegas do curso de pós-graduação. Thienes Maria C. Nashenveng, Antōnio Elisio M. Lobo, Jairo R. Jimenez Rueda, José Ernesto S. Pessotti e Valter de A. Benevides FiIho, pela solidariedade e amizade demonstradas.

Aos colegas do SNLCS, pesquisadores Maria AméIia de M. Duriez, Ruth Leal Johas e José Lopes de Paula, e têc nicos Maria Apparecida B. Pereira e António Moreira da Costa, por determinações efetuadas.

Aos professores e técnicos do CENA e do Departamento de Química da ESALQ, pelas leituras feitas nos espectrofotómetros de absorção.

Aos colegas do SNLCS, desenhistas-técnicos Cläu dio Edson Chaffin e Félix Emílio P. Cornejo,pela elaboração final das figuras apresentadas.

Aos funcionärios do Departamento de Solos, Geo logia e Fertilizantes da ESALQ, Tekla E. Klar. Nelci T. Manie ro, Vanda M. Zancheta e Dorival Albuquerque, pela ajuda prestada no decorrer do curso.

Ao professor José Joaquím Degásperi, da Faculdade de Fjlosofia, Ciências e Letras da USP, pela revisão do texto em portuguès.

A colega do SNLCS, assistente administrativo He loisa Seabra de Pinho Arango, pela revisão do texto em inglés.

$$
\text { As colegas do SNLCS, pesquisadoras Gilda de Pá }
$$


dua Paolinelli e Neli do Amaral Meneguelii, e bibliotecária Marynice M. Matos, pelo seu auxilio, respectivamente, na parte de estatistica e na revisäo da listagem da literaiura cita da:

A professora Elocy Minusi, da UFSM, e ao professor Evoneo Bexti Filho. da ESALQ, pela amizade constante. 


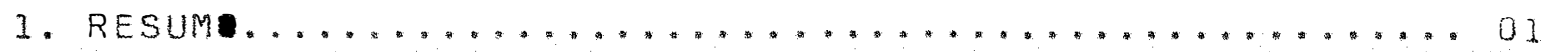

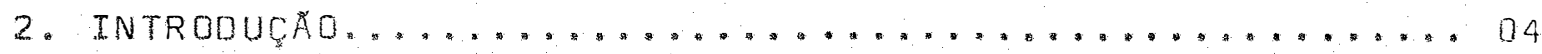

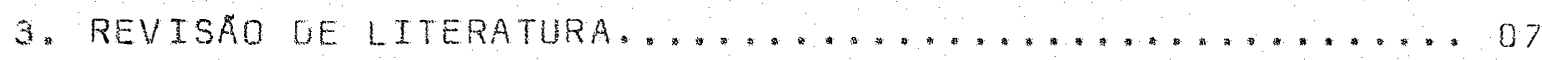

3.1. Relação entre solos e a paisagen....................

3.2. Implicapóes das formas de alumínio, ferro e mange-

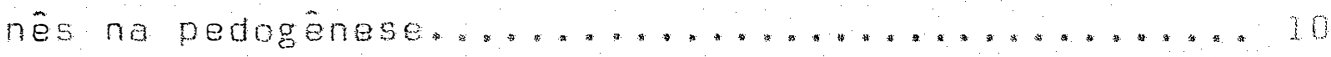

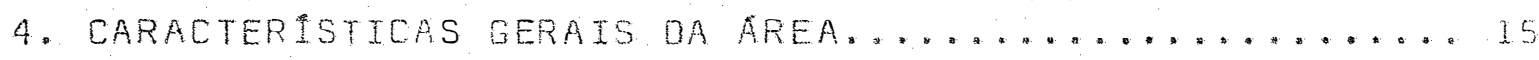

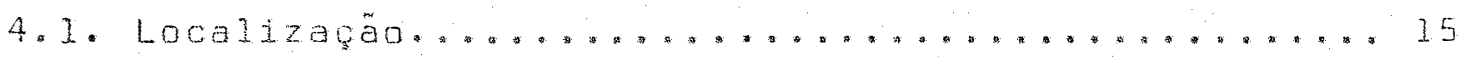

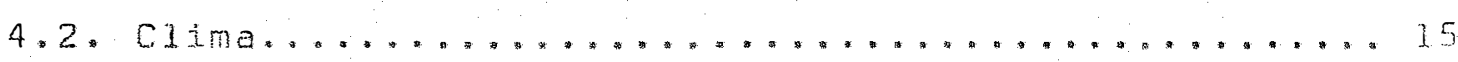

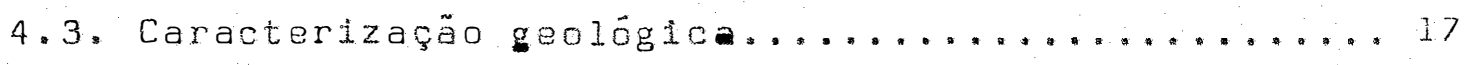

4.4. Relevo - Fundamentos geológicos do modelado......20

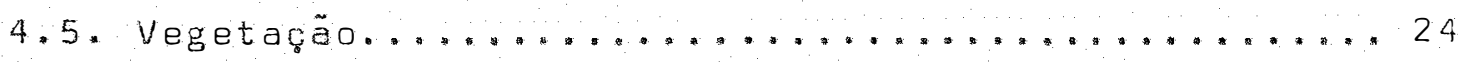

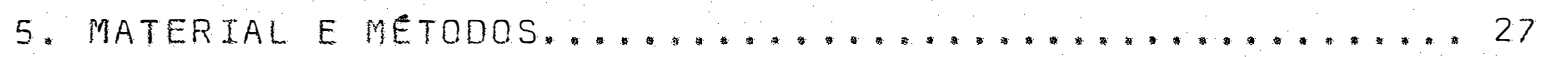

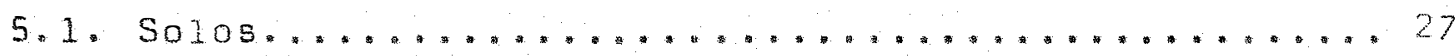

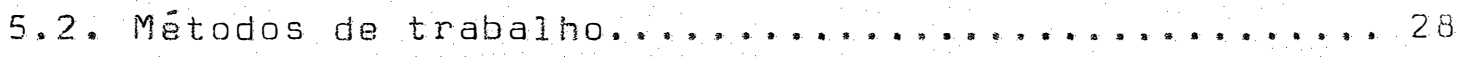

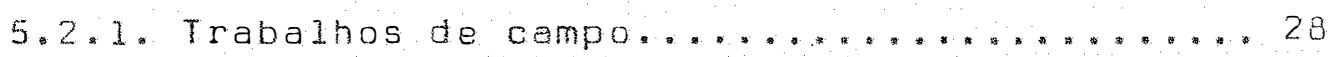

5.2.2. Trabalhos de laboratório..............28

5.2 .2 .1$. Determiną̧öes físicas........29

5.2 .2 .2$. Determinações químicas..........30

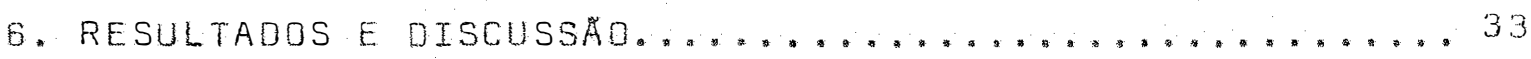

6.1. Características morfolögicas...................33

6.2 . Caracteristicas fisicas $\ldots \ldots \ldots \ldots \ldots \ldots$

6.2 .1$. Granulometria...................... 40

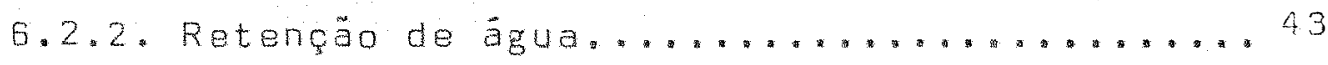


vii

Página

6.2.3. Floculacão da argila..................4.49

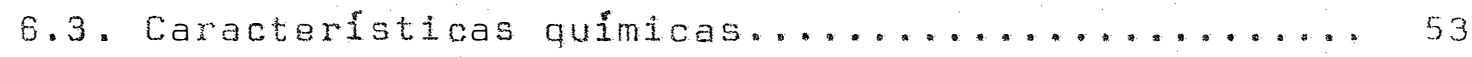

6.3.1. Caracteristicas químicas relativas à ferti

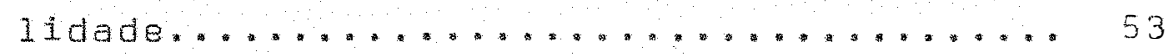

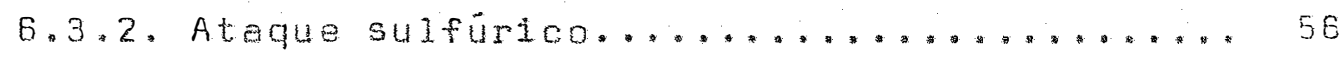

6.3.3. Extraçoos seletivas de ferro, alumínio e

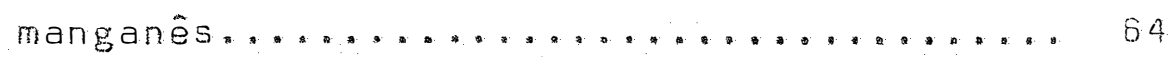

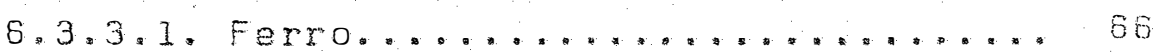

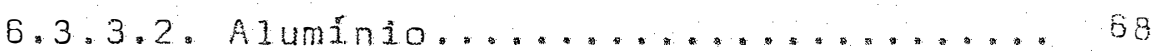

6.3.3.3. Manganês.................. 71

6.4. Classificação dos solos............................ 74

6. 5. Relação entre os solos e a paisagem............77

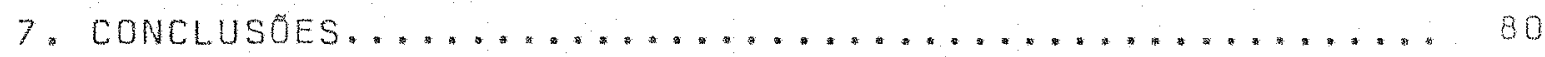

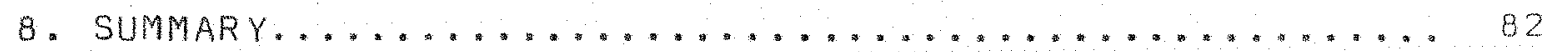

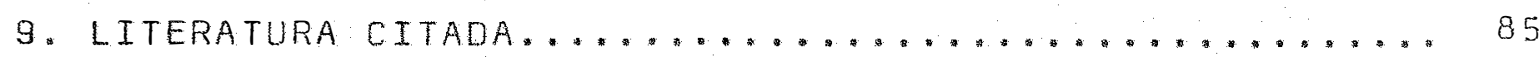

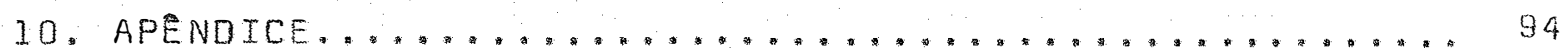


Quadro 1 - Dados climäticos da região de Pirapora $\left(17^{\circ} 21^{\prime} \mathrm{S}\right.$ e $44^{0} 57^{\prime}$ W.G.J no periodo 1931 a $1960 \ldots \ldots \ldots$

Quadro 2 - Distribuigão do tamanho de particulas na fração

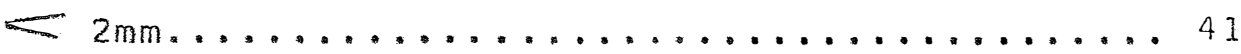

Quadro 3 - Agua disponível e teores de carbono orgânico,ar gila e ferro livre nos diversos horizontes dos quatro perfís estudados.................48

Quadro 4 - Argila total e dispersa em água, grau de floculą̧ão e $\triangle p H$ na fração $<2 m m \ldots . . . \ldots .50$

Quadro 5 - Características químicas dos solos estudados... 54 Quadro 6 - CTC e percentagens de argila e carbono orgánico e valores de CTC e carbono orgânico para I00 gramas de argila..................... 57

Quadro 7 - Dados obtidos pelo ataque sulfürico $\left\{\mathrm{H}_{2} \mathrm{SO}_{4} \mathrm{~d}=\right.$ 1.47 e $\mathrm{Na}_{2} \mathrm{CO}_{3}$ a $5 \%$ e relações entre silica e sesquioxidos...........................61

Quadro 8 - Teores de $\mathrm{Fe}_{2} \mathrm{O}_{3}$ extraĩdos, fraçäo Fe-silicato, razão de atividade do ferro e percentagem de ar

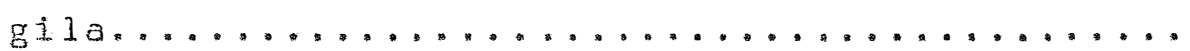

Quadro 9 - Teores de $\mathrm{Al}_{2} \mathrm{O}_{3}$ extraídos, fração Al-silicato. razão de atividade do alumínio e percentagem de

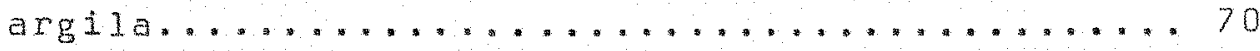

Quadro 10 - Teores de $M n_{2}{ }_{3}$ extraidos e percentagens de car bono orgànico dos solos estudados..............3 


\section{LISTA DE FIGURAS}

Página

Figura 1 - Localização da ärea de estudo - Jequitaí(MG).. I6

Figura 2 - Anticlinal de serra da Onça e vale do Rio Je-

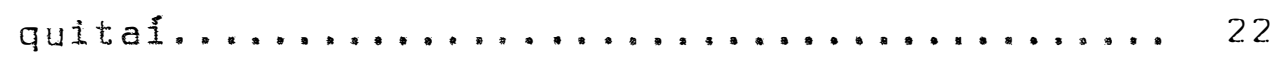

Figura 3 - Corte esquemático da topossequéncia estudada.. 23

Figura 4 - Aspecto geral do relevo da região.......... 25

Figura 5 - Aspecto da vegetação da área de estudo fflores

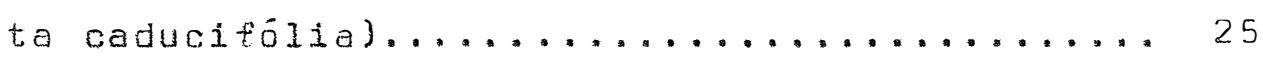

Figura 6 - Distinção relativa entre horizontes dos solos 29

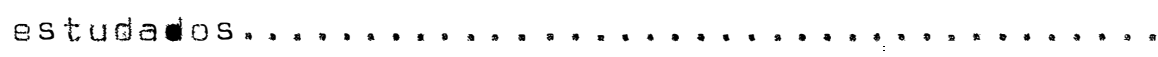

Figura 7 - Distribuição de argila dos solos estudados....4 42

Figura 8 - Relação entre o teor de silte e a distância do rio são francisco........................44

Figura 9 - Retenção de água pelos solos, a 1/3 e 15 atmos feras, na amostra secada ao ar e teores de argila e carbono orgànico.................46

Figura 10 - CTC para l grama de carbono na presença de 100 gramas de argila no perfil ........... 58

Figura 11 - CTC para l grama de carbono na presença de 10 gramas de argila no perfil $3 \ldots \ldots \ldots . . . . . .59$

Figura 12 - Aspecto do perfil $1 \ldots \ldots \ldots \ldots \ldots \ldots$

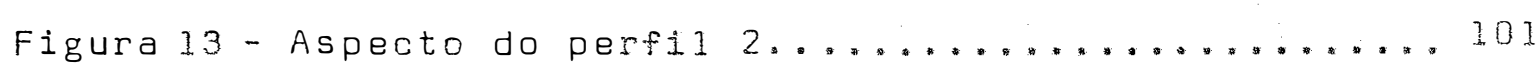


1. RESUMO

Foram estudadas caracteristicas morfológicas, fi sicas e químicas de quatro perfis de solos localizados em uma sequência catenäria da região de Jequitaí. Estado de Minas Ge rais. Operfil 1, um Latossolo Vermelho-Amarelo Alico A moderado textura mëdia (Typic Haplorthox), está localizado na super fície mais antiga; o perfil 2, um Podzólico Vermelho-Amarelo Alico latossólico plíntico (Plinthic Paleustult), está locali zado em uma superficie mais baixa que a anterior; o perfil 3 , uma Laterita Hidromórfica Alica argila de atividade baixa A moderado textura siltosalargilosa (Oxic Plinthaquult), ünico de drenagem imperfeita na topossequéncia, localizado na värzea e, finalmente, o perfil 4. um Brunizem Avermelhado textura média (Udic Paleustoll), o mais jovem da catena, localizado en uma pestana próxima ao rio São Francisco.

Os dados evidenciaram que existe uma relaça en tre os solos e a posição no relevo, sendo que os solos mais intemperizados (perfis I e 2 ) estão localizados no terragomois 
elevado, enquanto os menos intemperizados (perfis 3 e 4) se localizam no terraço de várzea. Consequentemente, o horizonte óxico ocorre na superfície mais antiga, e o argilico nas superficies mais recentes.

A ocorrência do horizonte argjilico no perfil 4 , em material holocênico e próximo à margem do rio são francisco, só poderia ser esclarecida mediante estudos geomorfológicos e pedológicos mais detalnados.

Existe uma relação entre a classificação dos solos pelo sistema americano e a evolução dos solos: assim ê que, partindo dos solos mais jovens para oa mais antigos, a sequencia encontrada é: Mollissolo, Ultissolo, Oxissolo.

No desenvolvimento dos trabalhos buscou-se ave riguar as formas de ferro, alumínio e manganês usando cinco extratores: ataque sulfürico, ditionito-citrato de södio, ditionito-citrato-bicarbonato de södio, oxalato ácido de amónio e pirofosfato de södio. O ditionito-citrato-bicarbonato de só dio parece ser o melhor extrator para ferro e manganés. porém, quanto a oxissolo e ao Ultissolo situado na superfócie geomōrfica contigua, uma só extração não foi suficiente para retirar todos os óxidos livres presentes. o ditionito-citrato de södio foi de um modo geral mais eficiente na extração dos óxidos livres de alumínio. Usou-se este extrator para avaliar as razões de atividade tanto do aluminio quanto do ferro porque. embora os teores absolutos deste ültimo elemento possam ser menores, o ditionito-citrato parece fornecer, neste traba 
Iho, dados relativos mals válidos quanto a distribuição dos ó xidos livres na topossequência.

Verificou-se que, embora os teores de ferrocom plexado pela matéria orgânica sofram a influência tanto da idade do solo quanto da drenagem, as razöes de atividadedofer ro podem ser usadas como um índice de intemperismo.

o aluminio organo-complexado acusa, mais forte mente que o ferro, a influéncia da drenagem e idade do solo.A grande contribuiçäo da fração amorfa no total de óxidos livres sob ambiente redutor impede que a razão de atividade do alumínio seja considerada um indice de intemperismo.

Sob ambiente redutor, o manganês se comportade modo oposto ao ferro e ao aluminio, apresentando teores minimos de öxidos livres. No solo mais jovem, está totalmente con tido na fração amorfa. A partir deste solo em direção aos solos mais velhos, o ataque sulfürico fornece valores de manganés superiores aos dos outros extratores. 
A partir da década de 60, o Governo Federal vem dando grande apoio ao Plano Nacional de Irrigação. Dentro des se plano, o vale do rio São Francisco foi estudado de um modo muito geral pela AID (2967), que forneceu as informações sobre solo, clima e água, e fez os estudos de viabilidade econômica para projetos de irrigação e colonização.

No Programa Plurianual de Irrigaçäo CGEIDA-MIN TER. 1971), a bacia do rio São Francisco foi considerada sepa radamente, constituindo uma região prioritária. Dentro dessa região, o projeto Jequitai, localizado na bacia do alto São Francisco, teve prevista, em uma primeira etapa, uma área irrigável de 6.300 ha, do total de 54.300 ha de área líquida cul tivāvel.

A Codevasf, antiga Suvale, através de contratos com entidades püblicas e privadas, instalou alguns projetos de irrigação em pölos de colonização sob sua responsabil I dade, como é o caso do projeto Jequitaí. Devido ao elevadocus 
to de instajação desses projetos, as äreas irrigadas ou poten cialmente irrigäveís devem ser cultivadas sob um sistema de manejo intensivo, o que implica na caracterizaçõo e interpretação das propriedades dos solos, a fim de estabelecer as suas İmitações de uso.

O Serviço Nacional de Levantamento e ConservaÇäo de Solos (SNLCS-EMBRAPA) vem dando prosseguimento às pesquisas que visam estabellcer normas para a utilização e conservação dos solos brasileiros. Essas pesquisas foram inicia das em 1953, objetivando o levantamento sistemático dos solos para a confecção do mapa de solos do Brasil a nível de reconhecimento. As equipes de técnicos do SNLCS. sejam de levanta mento ou de laboratório, trabalhar hoje em projetos que abran gem äreas situadas nas Regiões Norte, Nordeste, Sudeste, Centro-Oeste e Sul do país, além de desenvolver pesquisas especiais.

E apreciável a contribuição de estudos de áreas selecionadas, como subsidio a levantamentos detalhados de determinadas regiões e zonas correlatas. Há também. necessida de de testar. dentro das condições dos laboratörios, procedimentos especificos que auxiliem na definição de certas características dos solos.

Com base nesses antecedentes foi executado o presente estudo, envolvendo uma topossequénaia de solos localizados na região sub-úmida do Jequitar, com os seguintes objetivos: 
a. Caracterizaçäo morfológica, física e química de quatro perfis de solos representativos da região,

b. Estudo das formas de ocorrencia de ferro. a luminio e manganés en tiats solos.

c. Estudo da evolução das propriedades dos solos baseado na posição que ejes ocupam na paisagem. 
3. REVISAO A LITERATURA

\section{I. Relação entre solos e a paisagem}

MILNE (1935), em seu artigo original sobre catena de solos, notou que os perfis mudavam em sentido trans versal do topo da elevação ao rio, de acordo com a topografia. MILNE et alii (1935) reconheceram quanto a evolução das formas do relevo pode afetar os solos ao apontar que "o grande plateau que jaz após o modelado do relevo leste-oeste contém material que desceu durante um longo período de peneplanação, e que, portanto, pode:

- Reter características impressas durante seus primeiros estágios de intemperismo:

- Ter adquirido novas características visto seu perfil ter-se desenvolvido sob condições de drenagem lenta e

- Ter sofrido um ajustamento mais recente devi do às condiçôes de drenagem restabelecida pe 
la elevação do peneplano ao plateau".

JENNY (1941) correlacionou catenas com o fator relevo ou topografia, em adição ao grau de declive, forma do declive, convexidade e concavidade, classe do declive e, possivelmente, exposição. além de certas características hidroló gicas - comumente referidas como drenagem.

THORP (1942) sugeriu o termo "micro-catena" pa ra um grupo de séries restrito a "solos sob condições de drenagem significantemente diferentes sobre uma mesma espécie de rocha matriz". Propós o termo "macro-catena" para um conceito mais amplo, que pode incluir solos com semelhança embora näo estritamente relacionados.

NYE (1954, 1955), estudando uma toposequência sem afloramento de rochas na Africa, ressalva que um estudo apenas do desenvolvimento vertical de um perfil omite metade do quadro. As relações laterais e variações entre horizontes nas sucessões catenärias dos perfis merecem igualmente ser es tudadas. Assinala que é impossivel compreender a formação dos perfis nas partes mais baixas do relevo sem que os membros das. partes mais altas sejam conhecidos, e que seja apreciada a im portáncia de fatores, tais como drenagem lateral e transporte de solo por arrastamento.

DIXEY (1955) apontou os inconvenientes de caracterizar as superficies pela sua idade cronológica, preferindo outros métodos, tais como usar o periodo geológico de repouso imediatamente antes de sua ruptura, ou a idade dos de 
pósitos acumulados durante a erosäo da superfície. Sob o as pecto pedológico, o ponto importante parece ser que as superfĺcies precisam de tempo para se desenvolver, e então os soIos com os quals elas estão associadas podem ser de idades mui to diferentes.

OLLIER (1959) observa que a correlação dos solos com as superficies, em termos de idade, implica que os pro cessos de formação do solo começam com o corte de uma superfície de erosão.

MULCAHY (1960) é de opinião que superfícies de elevada idade persistem apenas no modelado. Modificações meno res por erosão fazem com que sejam raras as superfícies de eLevada idade absoluta e, conseqúentemente, solos verdadeiramen te velinos. Deste modo, também são raras as correlações extritas de idade entre solos e superfícies.

De acordo com RUHE (1960), duas variantes de catena podem ser identificadas no campo. Em uma delas, a topo grafia de uma formação originalmente homogênea quanto ao carä ter litológico foi modelada por denudação, ou outro processo; as diferenças nos solos seriam então condicionadas pela drena gem, transporte diferencial de material erodido e lixiviação, translocação e redeposição de constituintes químicos móveis. Na outra variante, a topografía foi esculpida a partir de duas ou mais formaçós superpostas com diferenças litológicas. autor ressalta dois aspectos na definição de catena: (a) his töria fisiogräfica e (b) envolvímento da avaliação geomorfoló 
gica do modelado no conceito de catena.

DANIELS et alii [1971] dividiram as superficies geomorfológicas em duas: deposicional e erosional, sendo, como seus nomes indicam, uma formada por deposição de sedimentos e outra por erosão. Em muitos modelados, uma superfície po de ter elementos de deposição e de erosão e ambos são conside rados uma só superfície. Esses autores, discutindo a sequência de idade de uma superfíie erosional, estabeleceram o tempo zero de uma superficie geomorfológica como sendo a época em que ela foi pela primeira vez exposta à ação do intemperismo ou, em outras palavras, a época em que teve início a erosão. Em uma superfície deposicional marinha, o tempo zero poderia ser quando o ceano, ao retirar-se, teria exposto os sedimentos à ação do intemperismo. Por esta definição, a idade da su perficie geomorfolögica e dos solos a ela associados è a mesma. Esses autores assinalam ainda que, os dados sobre a gênese de solos, são mais seguramente interpretados quando se dis põe de informações geomorfológicas e estratigräficas.

3.2. Implicações das formas de alumínio, ferro e manganés. na pedogênese

MCKEAGUE et alii (1971) observam que, durante a dëcada de 60, os trabalhos envolvendo Fe nos solos passaram da tentativa de remover materiais tidos como impureza da argi la, para que ela tivesse sua verdadeira composição determinada, à tentativa de caracterizar a natureza e os teores de ma- 
terials secundärios contendo ferro, para relacionä-los com o desenvolvimento e a classificação dos solos. Assim, por exemplo. SCHWERTMANN (1959), restabeleceu o procedimento de TAMM e ampliou sua utilidade, mostrando que pode ser feita uma diferenciação aproximada entre Fe amorfo e öxidos cristalinos fi namente divididos, pela extração seletiva com oxalato ácido de amōnio e ditionito-citrato-bicarbonato de sódio. MckEAGUE e DAY (1966) testaram este método de diferenciação e o usaram no desenvolvimento de critérios para distinguir horizontes es pödicos de outros horizontes enriquecidos em ferro. BLUME e SCHWERTMANN (1989) usaram dados da extração de Fe. Al e Mn por ditionito-citrato-bicarbonato de södio e oxalato de amönio para interpretar a gênese de várias classes de solos.MckE AGUE et aIii (1971) ressaltam a necessidade de estender essa diferenciação entre formas mais ou menos cristalinas e Fe amorfo a uma posterior diferenciação desta fração, ou seja, en tre ferro organo-complexado e ferro inorgánico amorfo.

Segundo BLUME e SCHWERTMANN (1969), os elemen tos Fe, Al e Mn são grandemente afetados pelos processos de gênese do perfil do solo. A distribuição desses óxidos e hiaróxidos no perfil, deste modo, auxilia na descrição do tipo, direção e extensão dos processos pedogênicos e pode ser usada para definir grandes grupos e outras classes de solos. Ressal vam entretanto, que na avaliaçäo desses óxidos pedogénjoos em função da profundidade, certos procedimentos e precouções säo necessärios. Em solos desenvolvidos de material parental home gêneo, a distribuição e a forma de ocorrência desses óxidos em 
profundidade sấo o resultado de diversos processos pedogenéti cos, e somente o resultado final pode ser observado. Lixiviação de carbonatos e acumulação de matëria orgânica ou outras alterações marcantes da massa do solo, podem mudar o conteúdo de öxidos de um horizonte em relafão a outro, por simples con sentração ou diluição. Tais alterações são chamadas alterações relativas. Alteraçóes causadas por eluviação e iluviação e li beração de óxidos dos silicatos são chamados alterações absoIutas. Elas podem muitas vezes ber identificadas, apös a remoçä́ dos efeitos cle carbonatos e matéría orgánica, por análi se e cálculo. Observam anda os autores que, como o ferro e o manganês são nutrientes para as plantas, sua acumulação pela vegetação precisa ser considerada. Este fato é especialmente verdadeiro em relação ao manganés, uma vez que, elevada proporção do manganés total participa do biociclo. Em materiais parentais heterogéneos (estratificados), as funções em profun didade do Al. Fe e Mn podem ser avaliadas somente se a fração a ser estudada for pequena ou ausente nos materiais de origem. Isto se aplica frequentemente às frações mais móveis tais como o. ferro solüvel em oxalato. SCHWERTMANN et alii (1968)es tudando a influência dos compostos orgànicos na formação dos áxidos de ferro, observaram que a sua retenção pelos hidróxi dos de ferro amorfos impede a cristalizaçäo, o que explica os altos teores de hidróxidos amorfos nos solos ümidos e na presença de matéría orgànica. 
formação de solos tropicais baseada no grau de intemperismo e composição mineralögica, que por sua vez se devem às influênclas do clima, drenagem, vegetação e tempo. observa que, em solos tropicais, as condiçōes de formação e a drenagem livre favorecem tanto a lixiviação como a dessilicatização. Contínua dessilicatização dará o produto final - o solo óxico - e somente a drenagem imperfeita ou impedida produzirä condições para ressilicatização e formação de minerais de argila nos tró picos. observa ainda que, quando os minerais de argila se as sociam com quantidades apreciáveis de óxidos livres, ocorre considerävel modificação das propriedades físicas e químicas dos solos. Estabilidade estrutural, movimento de água e capacidade de troca de cations (CTC) podem ser bastante alteradas. A fração coloidal amorfa do solo exibe uma ampla faixa degrau de hidratação, CTC e outras propriedades. Assim. KANEHIRO e SHERMAN (1956) mostraram que solos com elevados conteúdos de minerais hidratados amorfos perdem uma grande porção de sua CTC quando secados ao ar, enquanto SHERMAN (1957) mostrou que, na sua desidratação, a mudança de estado produziu a cristalização diferencial de gibbsita e óxidos de ferro. FIELos e SWINDALE (1954) mostraram que o sistema amorfo precede o desenvolvimento de minerais cristalinos. De modo anälogo. BATES (1959) sugere que na decomposição de um sistema cristalino (haloisita) e desenvolvimento subseqüente de um segundo mineral cristalino (gibbsita) desenvolveu-se um sistema amorfo. Em ambientes úmidos onde as estações secas não são intensas, verifica-se certa estabilidade do sistema amorfo, de modo que 
os solos desenvolvem sistemas coloidais amorfos quase completos, como ocorre nos Hydrol Humic Latosols e no horizonte B dos Latossolos ferruginosos do Havaí. Em tais solos o sisteme mineral é: Al, Fe, Si, Ti hidróxidos e óxidos hidratados co

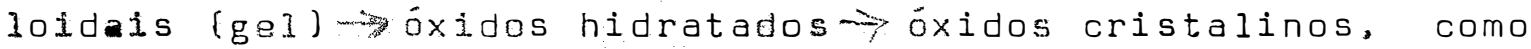
proposto por TAMURA e JACKS (1953). O sistema, então, pode ser reduzido a: (a) sistema iónico $\rightarrow(b)$ sistema amorfo $\rightarrow(c)$ sistema criptocristalino $\rightarrow(d)$ sistema cristalino. 
A área utilizada para o presente estudo perten ce ao Município de Jequitaí. Está situado na região do Alto São Francisco, no Estado de Minas Gerais (Figuna 1). A sede do Municipio de Jequitaí apresenta as seguintes coordenadas geográficas: $17^{\circ} 10^{\prime} 30^{\prime \prime}$ de letitude sul e $44^{\circ} 26^{\prime} 18^{\prime \prime}$ de longitu de - Gr.

4.2. Clima

Os dados climäticos relativos à área levantada foram obtidos dos registros de Pirapora, como exposto por RAN zani et alii (1977). Os dados relativos á precipitạão e temperatura são referidos ao perfodo 1931-1960. As médias mensais são apresentadas no Quadro 1, no qual se acham inscritas as e timativas da evapotranspiraçäo mensal, obtidas pelo método de THORNTWAITE 8 MATHER 91955). 


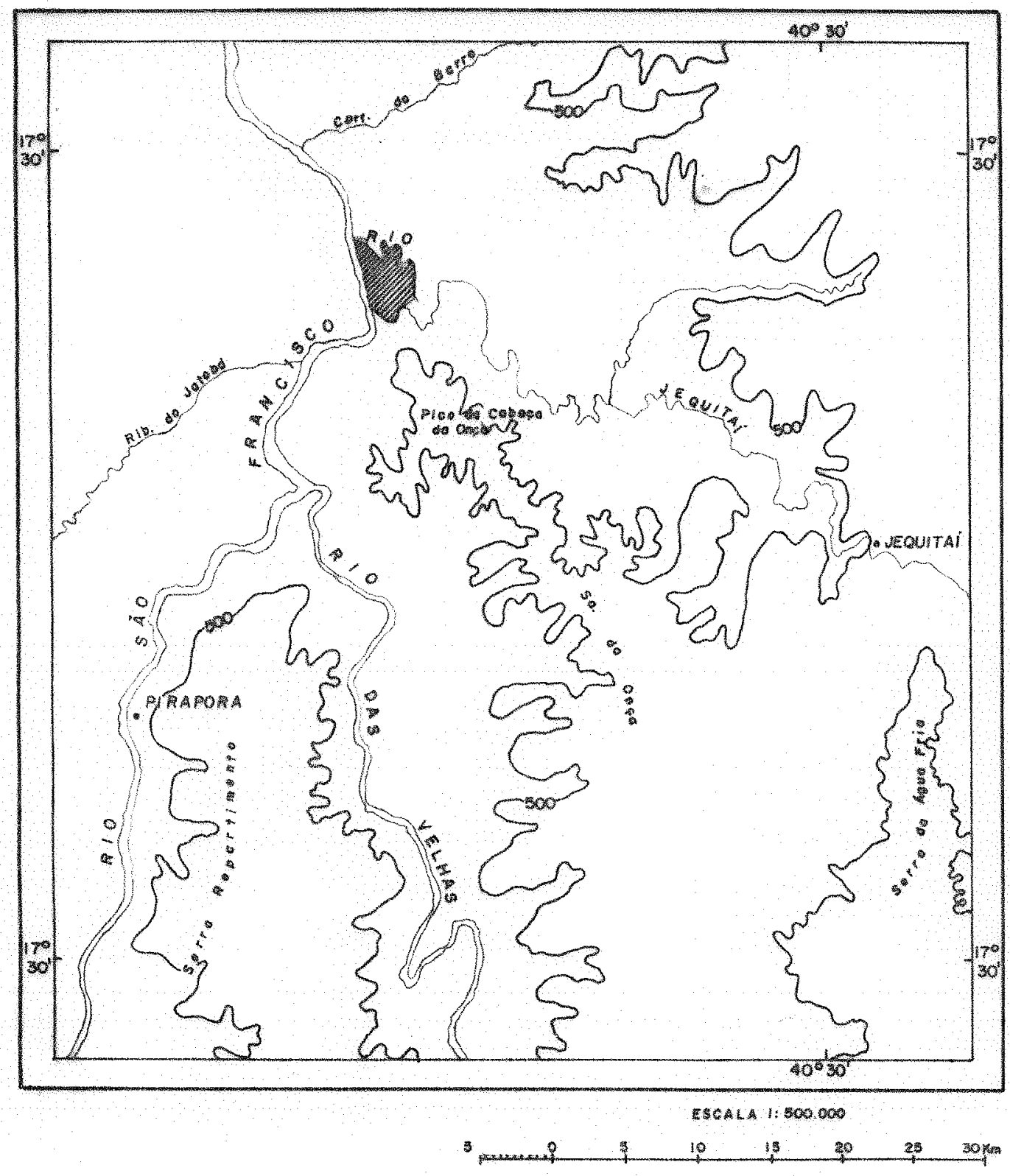

Figura 1 - Localizaça da area de estudo-Jequitaí (MG). 
o clima da região se caracteriza por uma preci pitação anual de $1.145 \mathrm{~mm}$ assim distribuídos:

- primavera (S, D, N) com $296 \mathrm{~mm}$ de chuva ou 26: da precipitação anual:

- verão (D, J, F) com $641 \mathrm{~mm}$ de chuva ou $56 \%$ da precipitação anual,

- outono (M, A, M) com $201 \mathrm{~mm}$ de chuva ou $17 \%$ da precipitaçãa anualı

- inverno (J, J, A) com $7 \mathrm{~mm}$ de chuva ou $1 \%$ da precipitação anual.

o mês mais seco é agosto, com l mm de precipitạ̧ão. enquanto o mês mais ümido é dezembro, com $278 \mathrm{~mm}$. Como se pode observar no Quadro 1, a temperatura média mensal varia entre 19,7 e $25,3^{\circ} \mathrm{C}$, correspondendo a uma oscilação térmí ca de $5,6^{\circ} \mathrm{C}$. A temperatura média anual é de $23,3^{\circ} \mathrm{C}$. enquanto as mëdịas de inverno e de verão são respectivamente 20,3 e $24.6^{\circ} \mathrm{C}$, o mês mais frio é julho, com $19,7^{\circ} \mathrm{C}$, enquanto o mais quente é outubra, com $25,3^{\circ} \mathrm{C}$. Como se observa, a diferenga en tre as temperaturas mëdias de verão e de inverno fica em torno de $5^{\circ} \mathrm{C}$.

4.3. Caracterização geológica

A litologia da ärea, como indicado em relatório do IPT (INSTITUTO DE PESQUISA TECNOLOGICA - Relatório $n^{*}$ 6.174 - São Paulo\} é a seguinte: 
Quadro 1 - Dados climátlcos da região de Pirapora $\left(17^{\circ} 21 \cdot \mathrm{S}\right.$ e $44^{\circ} 57$ 'W.G.) no perlodo 1931 a 1960 (mëdias mensais).

\begin{tabular}{|c|c|c|c|}
\hline Mès & $\begin{array}{l}\text { Precipitação } \\
\text { (mm })\end{array}$ & $\begin{array}{c}\text { Evapotranspiração } \\
\text { potencial } \\
\text { (mm })\end{array}$ & $\begin{array}{c}\text { Temperatura } \\
\left({ }^{0} \mathrm{C}\right)\end{array}$ \\
\hline Janeiro & 220 & 126 & 24,7 \\
\hline Fevereiro & 143 & 112 & 24,9 \\
\hline Março & 127 & 118 & 24,7 \\
\hline Abril & 63 & 95 & 23,5 \\
\hline Maio & 31 & 73 & 21,3 \\
\hline Junho & 3 & 57 & 19,9 \\
\hline Jul ho & 3 & 58 & 19.7 \\
\hline Agosto & 1 & 75 & 23,5 \\
\hline Setemoro & 19 & 105 & 24.1 \\
\hline Outubro & 75 & 126 & 25,3 \\
\hline Novembro & 202 & 123 & 24,9 \\
\hline Dezembro & 278 & 121 & 24,4 \\
\hline Total anual & 1.145 & 1.189 Média anual & 23,2 \\
\hline
\end{tabular}


a. Grupo Lavras.

De idade pré-Cambriana, representada por quartzitos intercalando quartzo-sericita-xistos e metasiltitos. No topo deste grupo ocorrem brechas quartziticas com sei xos angulosos de quartzito e silex, além de pavimentos estria dos por geleiras sobre os quais se assenta o tilito do Grupo Jequitai.

b. Instrusivas básicas metamorfisadas

Constituem-se de um metadiabásia verde escuro que se encaixa nos quartzitos do Grupo Lavras e materiais do Grupo Jequitai.

c. Grupo Jequitaí.

Representado por metassiltitos e calcáríos recristalizados, subordinando-se metarenitos. Estes materials Eo-Cambrianos expōem o calcário localmente cortado por vênulas calciticas ou veios de quartzo piritizados.

d. Veios de Quartzo
Estes veios cortam a xistosidade dos Grupos La vras e Bambuí. O quartzo é lejtoso com zonas de quartzo cristalino.

e. Conglomerados.

Constituidos por seixos de quartzito em matriz arenosa com cimento silícico. São de idade Terciária. 


\section{f. Aluviöes}

De idade Quaternärìa, se constituem de siltes, argilas, cascalios e areias.

\subsection{Relevo - Fundamentos geolögicos do modelado.}

o relevo apresentado pela área encontra explicação nos fundamentos estruturais e litológicos expostos por RANZANI E SELDON (197I)*, PENTEADO (1972) e PENTEADO E RANZANI (1973). Estes autores põem em evidēncia a estrutura regional, ressaltando o seu caräter sinclinal ao longo da depressão san-franciscana e em ạlguns afluentes do rio Jaquitaí. 0 contato das séries paleozöicas com o pré-Cambriano se faz por Iintias de falha e basculamentos do assoalho e da cobertura se dimentar (BRAJNIKOV, 1950; FREITAS, 1951; KING, 1956).

A literatura indica que na ärea, a Serra da On ça mostra o caráter das superfícies de pediplanação escalonada, onde camadas de resistências diferentes são truncadas por superficie erosiva. A Serra da Onģa (Figura 2) a 650-700 metros é mantida por arenitos metamorfizados e silicificados, quartzitos e calcários magnesianos, correspondendo à superfí cie de pediplanação mais antiga, isto é, à superfície Terciária (Neogénica-Pd2) que arrasou os relevos regionais em clima semi-árido, cortando estruturas resistentes e inclinadas dos arenitos metamorfizados e quartzitos. Essa superficie apresen ta dejeções de canga.

* Esquema topográfico-geológico Pirapora-Jequitaí-Värzea da Palma. 
Abajxo da Serra ança estende-se a superficie reglonal mais generalizada, onde ao nivel do Jequitas, a 40-550 metros de altitude, situa-se o local do estudo. Trata-se de um pediplano mals recente, desenvolvido sobre as for maçöes Cambro-ordovicianas por processos de intemperizaçäo me cânica e escoamento superficial em lençol, sob clima bem mais seco que o atual.

A superficie apresenta-se recoberta por depósi tos arenosos, frequentemente assentados sobre cascalheiras de quartzo e canga, com espessura de atë 20-30 metros. Esse material representa o remanejamento de antigos solos, desenvolvidos so bre os sedimentos paleozóicos da bacia e das bordas cristali nas desta. Sobre tais depósitos à altitude de 400-550 metros evoluiram os solos atuais do pediplano de Jequitaí.

A grande fase de pediplanaçäo do Pdl foj colocada no Pleistoceno Mëdio, por cronologia relativa (PENTEADO, 1972). No final dessa fase, $\theta$ abaixamento generalizado do eixo da bacia do São Francisco, possibilitou a deposição da Série Vazantes.

Como acontece no vale do Säo Francisco, o rio Jequitaí sofre levantamento de conjunto. As retomadas erosivas sub-atuais deram origem aos terraços:

- tl, em nível mais elevado, de 8 a 10 metros acima do leito dos rios, entalhado na Série Vazantes; 


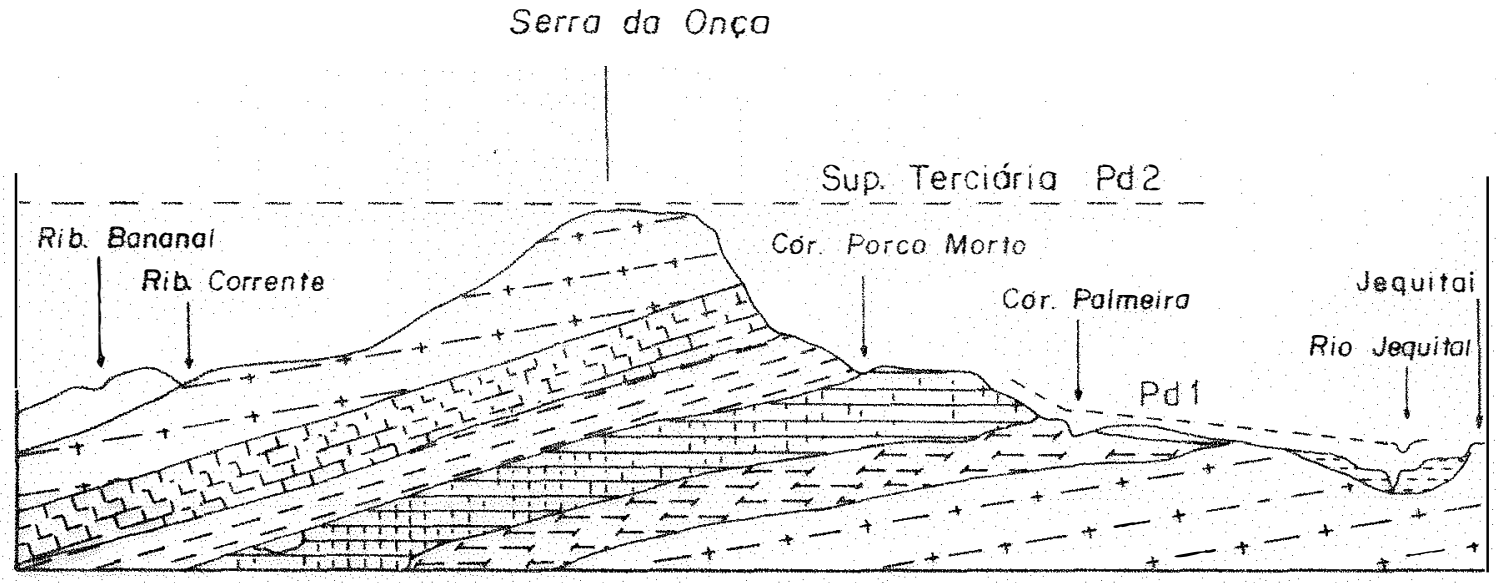

Escola 1:250000

FIGURA 2 - Anticlinal da serra da Onça e vale do rio jequitaí. 


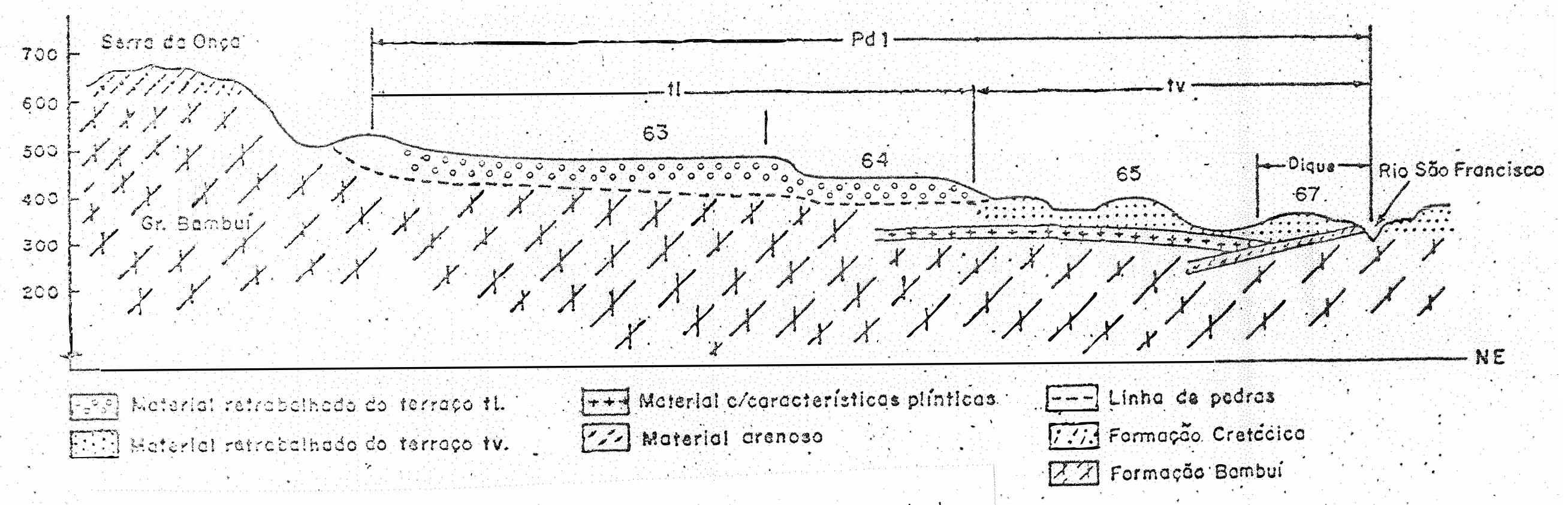


- tv, terraço de värzea entalhado em aluviões recentes, a 3-4 metros acima do leito dos rios,

Em resumo, trata-se de um modelado herdado das fases secas de pediplanação do final do Terciário até o Qua ternário. As formas se conservam em virtude da não ocorréncia dos contrastes climáticos durante o Quaternário, como observa do no Brasil de Sudeste.

\subsection{Vegetação}

As comunidades vegetais presentes säo as seguintes:

\section{Florestas (Matas)}

Associações com predominància de es écies arbó reas como a aroeira, o angico, o embiruçu, o açoita cavalo. o canafístula, o gonçalo-alves, o jatobá e o ipé.

\section{Cerrado}

Caracterizado por espécies arbustivas e arbóreas, tortuosas, cascudas, ocorrendo o tinguí, pau-terra, favela, cagaita, piqui e jacaré como as mais frequentes, além de um extrato rasteiro de gramíneas em manto descontinuo.

Pela modalidade de ocorrência, o cerrado tende a sugerir transiçöes para mata ou vice-versa, talvez provocadas pelo homem. E o que se observa na região pela frequéncia 


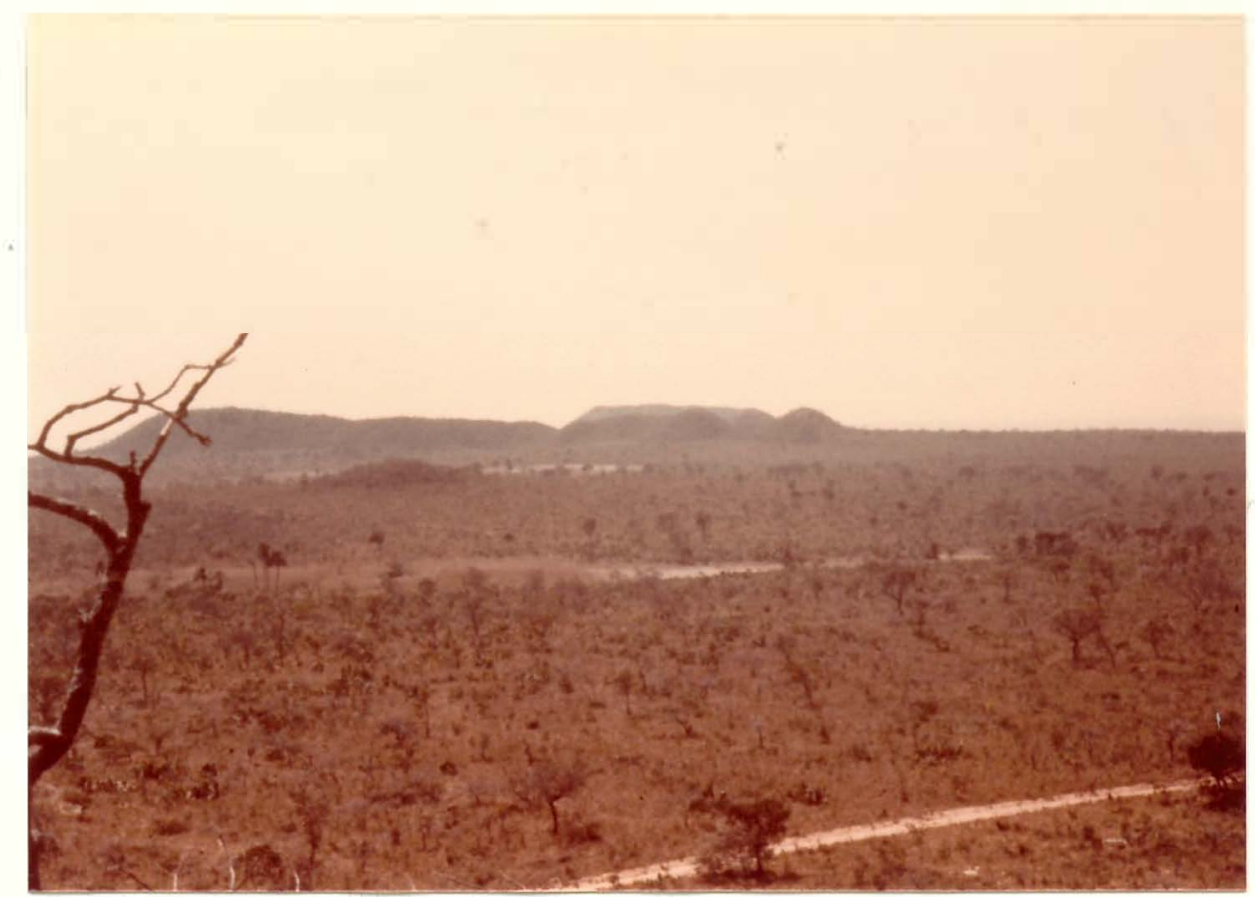

FIGURA 4. Aspecto geral do relevo da região.

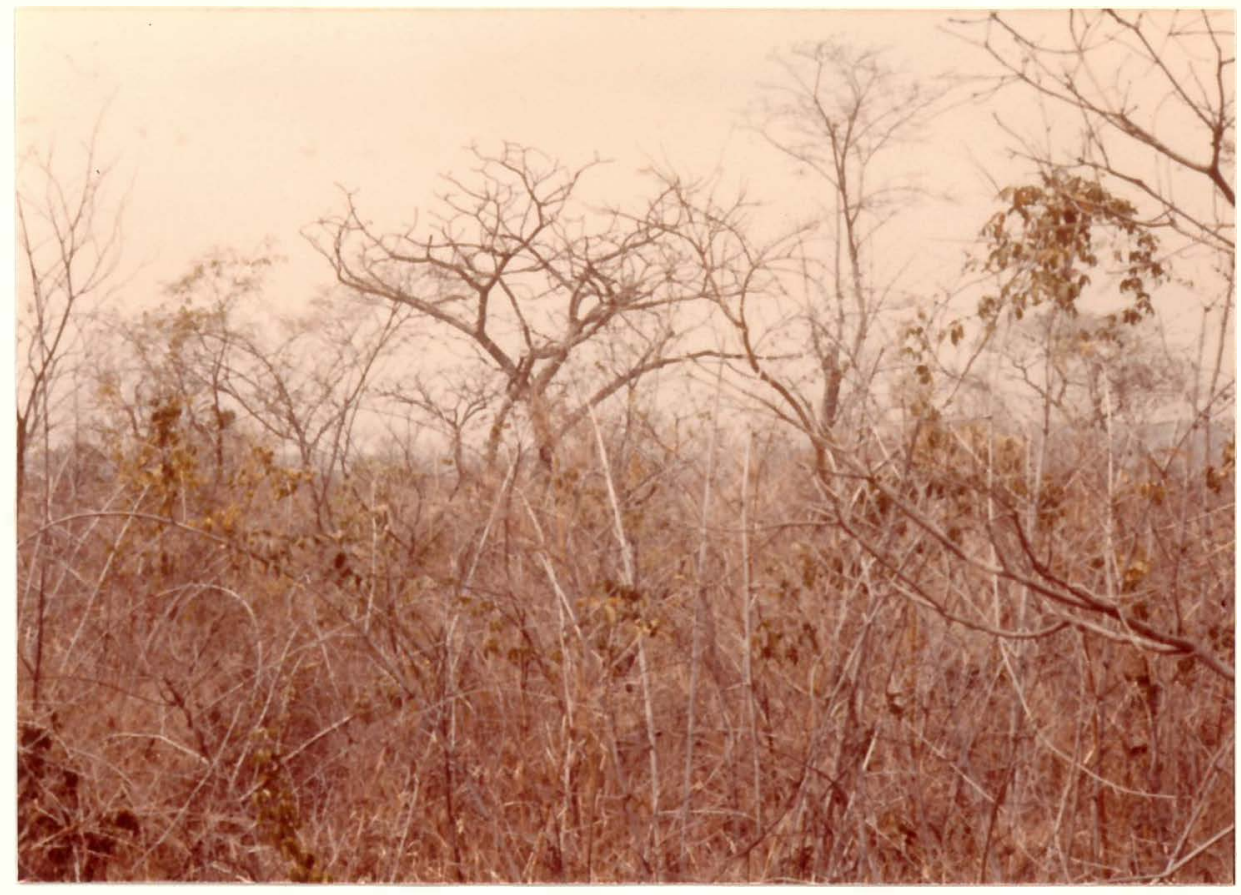

FIGURA 5. Aspecto da vegetação da área de estudo (floresta caducifólia). 
com que äreas de mata caducifólia se limitam com äreas de cer rado sob as mesmas condições de solo e de relevo.

o mesmo se pode dizer do cerrado em transição para campina e vice-versa.

\section{Campina de värzea}

Dominada pela presenca de um extrato rasteiro de gramíneas nativas, em geral de baixa palatabilidade, com raras espécies arbustivas. 
5. MATERIAL E METODOS

5.1. Solos

Foram selecionados quatro perfis de solos dispostos em uma sequencia catenária (RUHE, 1960), conforme ilus trado na Figura 3. Todos os perfis estão localizados no nível pedimentar Pdl de penTEADO (1972), colocado no Pleistoceno Mé dio. Trata-se de um pediplano sub-recente, desenvolvido sobre as formaçöes Cambro-Ordovicianas. Dentro deste nível pedimentar, os perfis 1, na altitude de $520 \mathrm{~m}$, e 2, na altitude de $510 \mathrm{~m}$, desenvolvem-se do material do terraço tl, constituindo a superficies mais antigas, enquanto os perfis 3 e a se desenvolvem do material do terraço de várzea - tv - mais recen te, fazendo parte de superficies mais jovens.

o perfil l, representativo da auperfície mais antiga e localizado na posiçäo mais alta da área estudada, é profundo, de textura média, com drenagen boa e carber latos. sólico. o perfil 2, localizado mais abaixo, em una superfície 
mais jovem que a anterior, è tambëm profundo e de textura nédia, com drenagem boa até a profundidade de $100 \mathrm{~cm}$, abaixo da qual se desenvolve um horizonte com características plinticas; possui aparentemente um horizonte B textural. 0 perfil 3, já localizado no terraço de várzea, tem drenagem. restringida e um caráter textural essencialmente siltoso. Finalmenteo per fil 4, localizado a aproximadamente $250 \mathrm{~m}$ do rio São Francis co, em um dique, é um solo relativamente profundo, com drenagem moderada a boa, também com textura de caräter siltoso, de senvolvendo um horizonte provavelmente $\theta$ textural. Estes dois ültimos solos se desenvolvem em superficies recentes.

\subsection{Métodos de trabalho}

5.2.1. Trabalios de campo

A caracterização morfológica (ver Apêndice) e a coleta de amostras dos solos foram feitas em trincheiras.Pa ra a descrição morfológica foi seguido o manual de metodo de TRABALHO DE CAMPO (LEMOS e SANTOS, 1976) e especificações do SOIL SURVEY STAFF $(1975)$.

5.2.2. Trabalhos de laboratório

Todas as determinações físicas e químicas foram procedidas na fraçäo menor que $2 \mathrm{~mm}$, com as seguintes exceções: densidade aparente - determinada no solo natural; umi 
dade residual do solo secado ao ar, ataque sulfúrico e extrações seletivas de ferro, alumínio e manganês - procedidas na fração menor que $2 \mathrm{~mm}$ tríturada em gral de porcelana. até pas sar totalmente em peneira com abertura de malhas de $0,149 \mathrm{~mm}$. Os resultados das análises são referidos à ter ra fina secada a $100-105^{\circ} \mathrm{C}$.

\section{$5 \cdot 2 \cdot 2 \cdot 1$. Determinaçães físicas}

Densidade aparente (Da) - determinada pelo mëtodo dó parafina, utilizando-se torrões do solo naturall BLAKE, $1965)$.

Densiciade real (Dr) - pelo mëtodo do picnómetro, usando-se -gua destilada (BLAKE, 1965 ).

Umidade retida a $1 / 3$ e 15 atmosferas - determinadas na amostra saturada, en comara de pressäo com placa porosa (RICHARDS $1965)$.

Umidade residual do solo secado ao ar - obtida pela diferença de peso entre a amostra secada ao ar e depois de secada em es tufa a 100-105 C por uma noite.

Porosidade total-VTP\% = (1-Da/Dr $) 100$.

Altura da coluna de água disponível - hmm $=A D \times D a \times H m m / 100$ $A D$ = água retida a $1 / 3$ atm. - água retida a 15 atm. Hmm = espessura do horizonte em milímetros. Granulometria - foi determinada pelo método da pipeta. usando se calgon como dispersante quimico e levando-se a a aitador de Wagner (120 Oscilações por minuto) durante uma noite (KIL- 
MER E ALEXANDER, 1949 \}.

Argila dispersa em água - conforme especificado no item acima, porëm sem o uso do dispersante químico.

Grau de floculação (GF) = (arg.total - arg.disp.em água) loo/ arg. total.

5.2.2.2. Determinações químicas

As análises quimicas foram procedidas segundo os métodos propostas por VETTORI (1969), exceto as determina ções dos óxidos livres de ferro, àlumínio e manganês.

pH em ägua e em KCl N/l - suspensão solo: líquido l: l e tempo de contato não inferior a uma hora,agitando-se a suspensão no vamente antes da leitura.

$\Delta \mathrm{pH}=\mathrm{PH}_{\mathrm{KCl}}-\mathrm{PH}_{\mathrm{H}_{2} \mathrm{O}}$ [GILLMAN, 1974$\}$.

Cálcio, magnésio e alumínio extraíveis por KCl N/l. Titulação: $\mathrm{Ca}^{++}+\mathrm{Mg}^{++}-$com EDTA, usando como indicador negro de eriocro mo.

$\mathrm{Ca}^{++}$- com o mesmo EOTA e murexida como indicador.

$\mathrm{Al}^{++}-\mathrm{com} \mathrm{NaOH}$, usando azul. de bromotimol como indicador. Potássio e sódio extraíveis por HCl 0.05 N - determinados por fotometria de chama.

Hidrogêniotalumínio extraíveis por acetato de cálcio N/l a pH 7,0-7, l - titulação com NaOH, usando fenolftaleína como in dicador.

Fösforo extraivel por HCl $0.05 \mathrm{~N} \mathrm{H}_{2} \mathrm{SO}_{4} 0.025 \mathrm{~N}$ (North Carolinal - determinado colorimetricamente pela reduçäo do comple 
xo fosfomolídico com äcido ascörbico em presença de sal de bismuto.

Ataque por $\mathrm{H}_{2} \mathrm{SO}_{4}(\mathrm{~d}=1.47)$ e $\mathrm{Na}_{2} \mathrm{CO}_{3}(\mathrm{a} 5 \%)$ - tratamento da ter ra fina secada a ar por fervura sob refluxo. Foram dosados a lumínio, ferro. manganés, titànio e fósforo no filtrado, e sí lica no residuo.

Alumínio e ferro - determiandos complexometricamente. Manganês e fósforo - determinados por fotometria de absorção atômica, usando como oxidante e combustível ar-acetileno. Titánio e sílica - determinados colorimetricamente.

$$
\text { As extraçöes seletivas dos óxidos livres de }
$$
ferro, alumínio e manganês foram feitas segundo os mêtodos: HOLMGREN (1967) - extração com ditionito-citrato de södio; MEHRA E JACKSON (1960) - extração com ditionito-citrato-bicar bonato de sódio;

MCKEAGUE e DAY (1966) - extração com oxalato de amōnio e BASCOMB (1968) - extrą̧ão com pirofosfato de sódio.

As concentraçöes foram lidas em fotómetrode ab sorçäo atômica Perkin-Elmer, usando chama de ar-acetileno para ferro e manganés, e óxido nitroso-acetileno para alumínio. As leituras deram diretamente a concentração em ppm (ug/ml\} do elemento no extrato.

Valor S (bases extraíveis - obtido pela soma dos teores de cálcio, magnésio, potássio e sódio extraiveis.

Valor T (capacidade de troca de cations) - obtido pela soma do valor se os teores de hidrogènio e eluminio extraíveis. Valor V (saturaçäo de bases) - calculado pela fómula loos/T. 
Saturação de alumínio - calculada pela förmula looAl ${ }^{+++} / \mathrm{Al}^{+++}+\mathrm{S}$. Capacidade de troca de cations por loo gramas de argila, com correção para carbono - calculada pela färmula CTC- (C $\times 4.5)$ 100/\% de argila, que fornece valores aproximados, e tambérn pe lo mëtodo gráfico proposto por BENNEMA (1966). 
6.1. Caracteristicas morfológicas.

$$
\text { As caracteristicas morfológicas do perfil 1, o }
$$
mais velho da topossequéncia, indicam uma grande homogeneidade ao longo do perfil, principalmente quanto a cor, consistén cia e grau de estrutura, com uma aparencia latossólica marcan te.

As variações de textura são pequenas, passando de areia franca nos dois horizontes superiores a franco areno so e franco argilo-arenoso nos horizontes subseqüentes. A estrutura é fraca e média nos três primeiros horizontes, evoluindo de granular no horizonte superficial a prismática no sub jacente, para então decrescer a fraca e em grumos ho horizonte inferior. Lima estrutura com grau fraco de expressão, como neste caso, indica um solo mutto intemperizado (VAN WAMEKE 1962). A consistenoia quando umido woria de fribuel no horizonte superficjal a muito friável nos demais horizontes, o que 
pode ser explicado por um conteúdo algo mais elevado de matéria orgânica no primeiro. Este horizonte é não plästico e não pegajoso, enquanto os demais sầ ligezramente plästicos e ligeiramente pegajosos. o que estä de acordo com as respectivas classes texturais, que são mais argilosas nos horizontes infe riores.

o horizonte superficial, de pequenas espessura, com limite claro, ë o único que se diferencia nitidamente no perfil. Os demais são pratieamente homogéneos, diferenciando- se levemente pelo tipo de estrutura, e pelo limite gradual ou difuso entre os horizontes.

Não há evidência de iluviação de argila ao lon go do perfil. No segundo horizonte, apenas algumas galerias biológicas apresentam paredes cerosas. Considerando principal mente o grau fraco da estrutura dos horizontes inferiores e seu caráter grumoso, a ausêneia de iluviação evidente, a ausèncla de minerais faclimente intemperizäveis (PESSOTTI, 1978) e o teor de argila superior a $15 \%$, esses horizontes podem ser enquadrados morfologicamente como um horizonte B latossólico(óxico segundo o SDIL SURVEY STAFF, 1975). As características de cor do horizonte superficial permitem o seu enquadramento como epipedon ócrico \{SOIL SURVEY STAFF, 1975 \} ou como um horizonte A moderado (BRASIL, 1973).

o perfil 2, situado em uma posig̨a fisiográfica imediatamente inferior àquala ocupada pelo perfil 1, possui um perfil relativamente homogèneo em suas propriedades 
morfológicas e até certo ponto semelhante ao perfil anterior. Entretanto, difere desse por apresentar um grau de estrutura e evidências de cerosidade já bem mais acentuados. o perfil apresenta uma característica geral latossölica mas se observa a formação de um horizonte argilico pouco desenvolvido.

A classe textural do horizonte superficial é franco arenoso, e a dos trés horizontes aubsequentes, franco argiloso. A estrutura é moderada no horizonte superior e fraca nos demais. O maior desenvolvimento do grau de estrutura no horizonte superficial pode ser atribuido ao conteúdo mais elevado de matéria orgânica (Quadro 3). A consistência do horizonte superficial é ligeiramente plástica e ligeiramente pe gajosa, passando a muito plästica e muito pegajosa nos horizontes subjacentes, o que está de acordo com o maior conteúdo de argila destes horizontes (quadro 2). 0 aumento de argila no horizonte B, aliado à presença de cerosidade, evidencia a ocorréncia de um horizonte argílico pouco desenvolvido nesse solo. As características de cor do horizonte superficial permitem definílo como um epipedon öcrico (SOIL SURVEY STAFF, 1975) ou como um horizonte A moderado (BRASIL, 1973). No últi mo horizonte, devido às variações de marchetamento ocasiona das pela oscilação do lençol freätico, desenvolveu-se um hori zonte plintico.

D perfil 3 situa-se na superfície fisiogräfica imediatamente inferior à do perfil 2, sendo ambos os solos in termediários entre os membros extremos da catena. E um solo 
que difere morfologicamente totalmentedos demais. Devido a sua posição de ocorréncia, em um terraço de värzea, ele possui quase todas as características de um solo que se desenvolve em ambiente redutor. As caracteristicas de cor, principalmente o marchetado e o mosqueado, refletem as oscilações do lençol freático e as condições de oxi-redução.

A classe textural é franco argilo-siltoso nos dois primeiros horizontes, argila siltosa no terceiro e franco argiloso no quarto horizonte, evidenciando a influência do material sirtoso nesse solo. os dois primeiros horizontes têm estrutura em blocos subangulares, evoluindo de moderada. média a fina no primeiro, a forte, médja a grande no segundo ho rizonte. Os dois ültimos horizontes têm estrutura moderada. grande, prismática. É muito plástico e muito pegajoso em todo o perfil, refletindo com isto também a influência do material fino, silte e argila. Apesar da relação textural ser baixa, a presença de cutan iluvial nesse solo (JIMENEZ, 1978*) possibi lita a identificação de um horizonte argílico, o epipedon pode ser enquadrado como ócrico (SOIL SURVEY STAFF, 1975) ou co mo horizonte A moderado (BRASIL, 1973). A presença de seixos quartziticos nos horizontes inferiores desse solo comprova que parte do material de origem foi retrabalhado.

O perfil 4 ocupa a superfície mais baixa da to possequência, a 250 metros da margem do rio São Francisco. De vido à sua localizaçäo em um dique, a drenagem é moderada a * JIMENEZ, R.J.R. 1978. Comunicação pessoal. 
boa. A cor dos dois primejros horizontes é bruno-acinzentado muito escuro (10 YR 3/2), o que, associado aos elevados teores de carbono orgänico e saturafão de bases define um epjpedon mólico (SOIL SURVEY STAFF, 1975) ou um horizonte A cherno zèmico (BENNEMA e CAMARGo, 1964). A classe textural é franco siltoso nos trés primeiros horizontes, franco no quarto efran co arenoso no quinto horizonte. Pela caracterizacäo da textura no campo, observa-se que ela ë mais arenosa no horizonte superficial. Conseqüenternente, há um ligeiro aumento textural entre os horizontes $A$ e B. Tal fato, aliado à presença de derosidade, define um horizonte argilico. A cerosidade neste ca so é mais desenvolvida por apresentar este solo uma drenagem jä mais ìvre.

Com o objetivo de levar a um gráfico o grau de desenvolvimento desses solos, tentou-se adotar os critérios descritos por BIhZI e CIOLKOSZ (1977a e 1977b). 0 resultado obtido é mostrado na Figura 4. Dbservar que:

a. Os solos das superfícies mais antigas (perfis l e 2) apresentam maior grau de distinçäo entre o horizon te superior e o subjacente que os solos das superfícies mais recentes (perfis 3 e 4 ).

b. Se o nümero de pontos que exprime a distinção entre os horizontes se mantém o mesmo, a linha que une seus limites superiores é uma perpendicular à linha que expressa o valor em pontos. 
c. Se o nümero de pontos que quantifica a dis¿inçäo entre dois horizontes diminui, a linha que une seus li mites superiores se inolina para a esquerda (por exemplo. a Inha que une os limites superiores do $2^{8}$ e $3^{8}$ horizontes do perfil l).

d. Se a distinção entre os horizontes aumenta. a linha se inclina para a direita, como entre o $2^{\circ}$ e $03^{8}$ horizontes do perfil 4 .

Considerando como no presente caso, quatro horizontes de referéncia e os três limites entre eles para cons truir o gráfico representativo da idade pedolögica de uma catena, o àngulo de deflexão dál resultante é sempre menor nos solos mais intemperizados, pois eles apresentam usualmente apenas o horizonte superior bem definido, com diferenças mínimas ao longo do perfil (ver perfil 1). Na linha que representa o perfil 2, o ângulo aumenta devido à major distinção entre os horizontes; na do perfil 3, aumenta devido a este fato e tambëm a ter diminuído bruscamente a distinção enter $03^{8}$ e o 48 horizontes, que estäo morfologicamente condicioriados pela drenagem restringida. Na linha que representa o perfil 4 , contido na superfície fisiográfica mais jovem, o àngulo é máximo, devido a fraca distinção sobre o horizonte superior e o subjacente (horizontesAll e Al2) e a marcante distinção entre estes e os horizontes subsequentes.

A aplicaçẽo deste método, como pode ser notado. permite a diferenciação entré os solos de uma catena. 


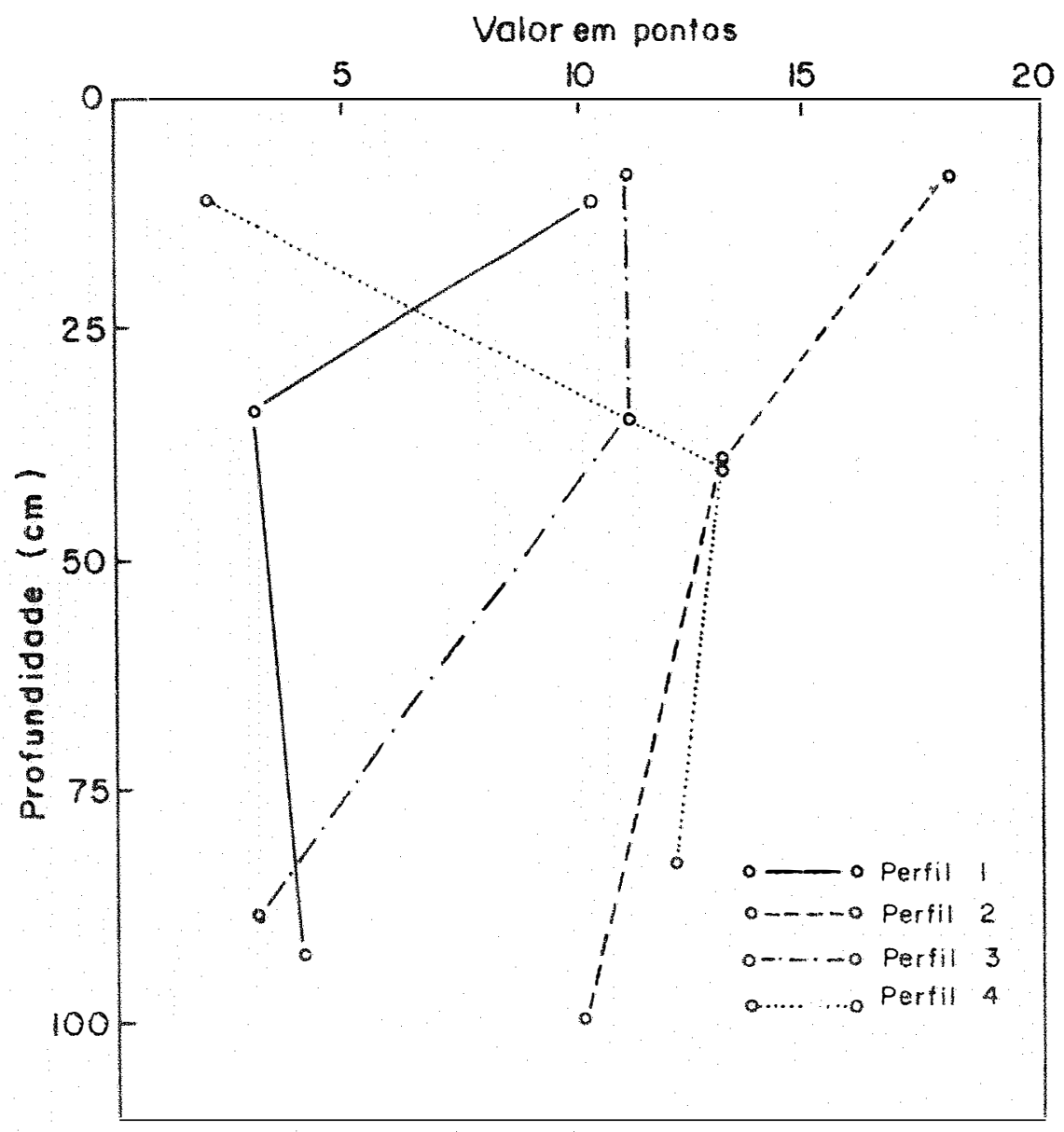

Figuro 6 . Distinçódo relotivo entre horizontes dos solos estudados. 


\title{
6.2. Earacteristicas físicas
}

\author{
6.2.1. Granulometria
}

o Quadro 2 apresenta a distribuição do tamanho de partículas dos solos estudados.

o perfil l é de caráter arenoso, com predominância das frações areia mëdia e fina. o conteüdo de argila au menta em profundidade, passando de 9,6\% no horizonte superfi cial a $21.1 \%$ no ültimo horizonte. Apesar de ser um aumento re lativamente grande, ele é gradual (Figura 7), não sendo consi derado expressivo quanto à diferenciação de um horizonte subsuperficial de acumulação de argila.

o perfil 2 é mä́s argiloso, e o aumento do con teúdo de argila em profundidade se verifica até ao $3^{8}$ horizon te. 0 incremento do teor de argila de $11,9 \%$ para $28,6 \%$, aliado à presença de cerosidade, possibilita a definição de um ho rizonte argílico. O teor de silte deste solo é elevado quando comparado ao do solo anterior. Isto é devido a ser o perfil l o mais velho da topossequéncia e a ter um material de origem de caráter mais arenoso.

o perfil 3 é de natureza siltosa. Isto se deve ao fato de estar este solo totalmente sob a influencia do rio São Francisco, e de ser seu material de origem de natureza sil to-argilosa. Apesar do pequeno incremento de argila, a presen Ça de cerosidade no horizonte $B$ define um horizonte argílico. A heterogeneidade do material de origem desse solo pode ser 
Quadro 2 - Distribuição do temanho de partículas na fração $<2 \mathrm{~mm}$ (\%)

\begin{tabular}{|c|c|c|c|c|c|c|c|c|c|}
\hline \multirow{2}{*}{$\begin{array}{c}\text { Profundi- } \\
\text { dade } \\
\mathrm{cm}\end{array}$} & \multicolumn{6}{|c|}{ Areia (m) } & \multirow{2}{*}{$\begin{array}{c}\text { silte } \\
(\mu) \\
2-50\end{array}$} & \multirow{2}{*}{$\begin{array}{c}\operatorname{Arg}^{j} 1 \mathrm{a} \\
\{\mu\} \\
<2\end{array}$} & \multirow{2}{*}{$\frac{a m f}{a f}$} \\
\hline & $2-1$ & $0,5-1$ & $\begin{array}{l}0,25 \\
0,5\end{array}$ & $\begin{array}{l}0.1 \\
0.25\end{array}$ & $\begin{array}{l}0.05- \\
0.1\end{array}$ & $\begin{array}{l}0.05- \\
2\end{array}$ & & & \\
\hline
\end{tabular}

Perfil

$\begin{array}{cccccccccc}0-12 & 1,2 & 8,4 & 30,6 & 29,5 & 10,1 & 79,8 & 10,6 & 9,6 & 0,34 \\ 12-32 & 1,5 & 7,8 & 27,2 & 26,6 & 8,1 & 41,2 & 16,4 & 12,4 & 0,30 \\ 32-92 & 1,5 & 10,2 & 26,2 & 20,8 & 8,6 & 67,3 & 13,6 & 19,1 & 0,41 \\ 92-150+ & 1,1 & 7,8 & 21,6 & 23,2 & 12,5 & 66,2 & 12,7 & 21,1 & 0,54 \\ \text { Perfi12 } & & & & & & & & & \\ 0-8 & 0,4 & 2,6 & 13,8 & 30,2 & 8,1 & 55,1 & 33,0 & 11,9 & 0,27 \\ 8-38 & 0,2 & 2,0 & 9,9 & 22,9 & 6,5 & 41,5 & 29,9 & 28,6 & 0,28 \\ 28-100 & 0,5 & 1,3 & 5,1 & 15,5 & 5,3 & 27,7 & 34,5 & 37,8 & 0,34 \\ 100-140+ & 0,4 & 1,5 & 4,1 & 12,6 & 6,3 & 24,9 & 43,6 & 31,5 & 0,50\end{array}$

Perfil 3

$\begin{array}{llllllllll}0-8 & - & 0,5 & 0,8 & 1,1 & 0,7 & 3,1 & 60,7 & 36,2 & 0,64 \\ 8-34 & - & 0,2 & 0,8 & 1,4 & 1,0 & 3,4 & 62,1 & 34,5 & 0,71 \\ 34-89 & - & 0,1 & 0,5 & 1,0 & 1,0 & 2,6 & 56,8 & 40,6 & 1,0 \\ 89-150+ & 0,4 & 0,9 & 7,0 & 18,0 & 8,2 & 34,5 & 36,4 & 29,1 & 0,46\end{array}$

Perfil 4

\begin{tabular}{|c|c|c|c|c|c|c|c|c|c|}
\hline $0-10$ & - & - & 0,9 & 17,6 & 4,3 & 22,8 & 63.2 & 14,0 & 0,24 \\
\hline $10-40$ & - & - & 1.4 & 22,3 & 6,6 & 30,3 & 50,9 & 18,8 & 0,30 \\
\hline $40-82$ & - & 0,1 & 2,0 & 20.1 & 2.7 & 23,9 & 53,4 & 22,7 & 0,13 \\
\hline $82-140$ & $\cdots$ & - & 2,4 & 36,2 & 9,6 & 48,2 & 33,9 & 17,9 & 0,27 \\
\hline $140-200+$ & -- & - & 2.6 & 57,6 & 13,8 & 74.0 & 9.6 & 16.4 & 0,24 \\
\hline
\end{tabular}




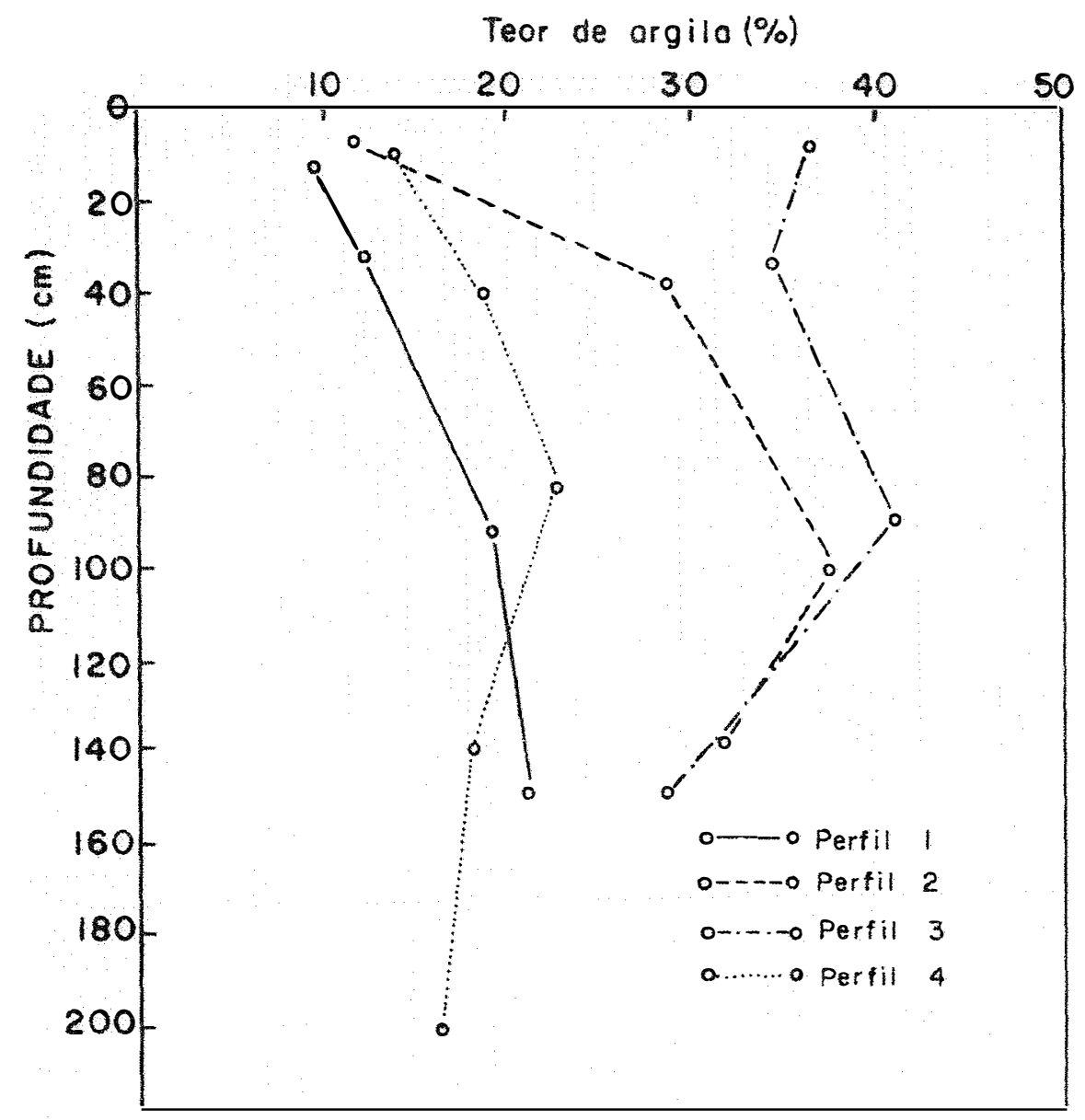

Figuro 7 - Distribuiçöo de argilo dos solos estudados 
notada pelos dados da relação areia muito fina/areia finalqua dro 2)

O perfil 4 ë também de natureza siltosa, estan do totalmente sob a influencia do rio São francisco, e seu ma terial de origem é de natureza silto-argilosa. A heterogeneidade deste material pode ser observada nos dados da relação a reia muito fina/areia fina (Quadro 2). O incremento de 14,0\% para 18,8\% de argila, aliado à evidéncia de argila iluvial as sinalada na descrição morfológica, caracterizam um horizonte $\operatorname{argijico.~}$

Dentre os solos estudados, o perfil 1 parece ser o mais homogéneo. O perfil 2 apresenta uma variação de 0.34 para 0,50 nos valores da relação areia muito fina/areia fina dos horizontes inferiores. Os demais solos apresentam, a profundidades variáveis, evidências semelhantes (Quadro 2 ).

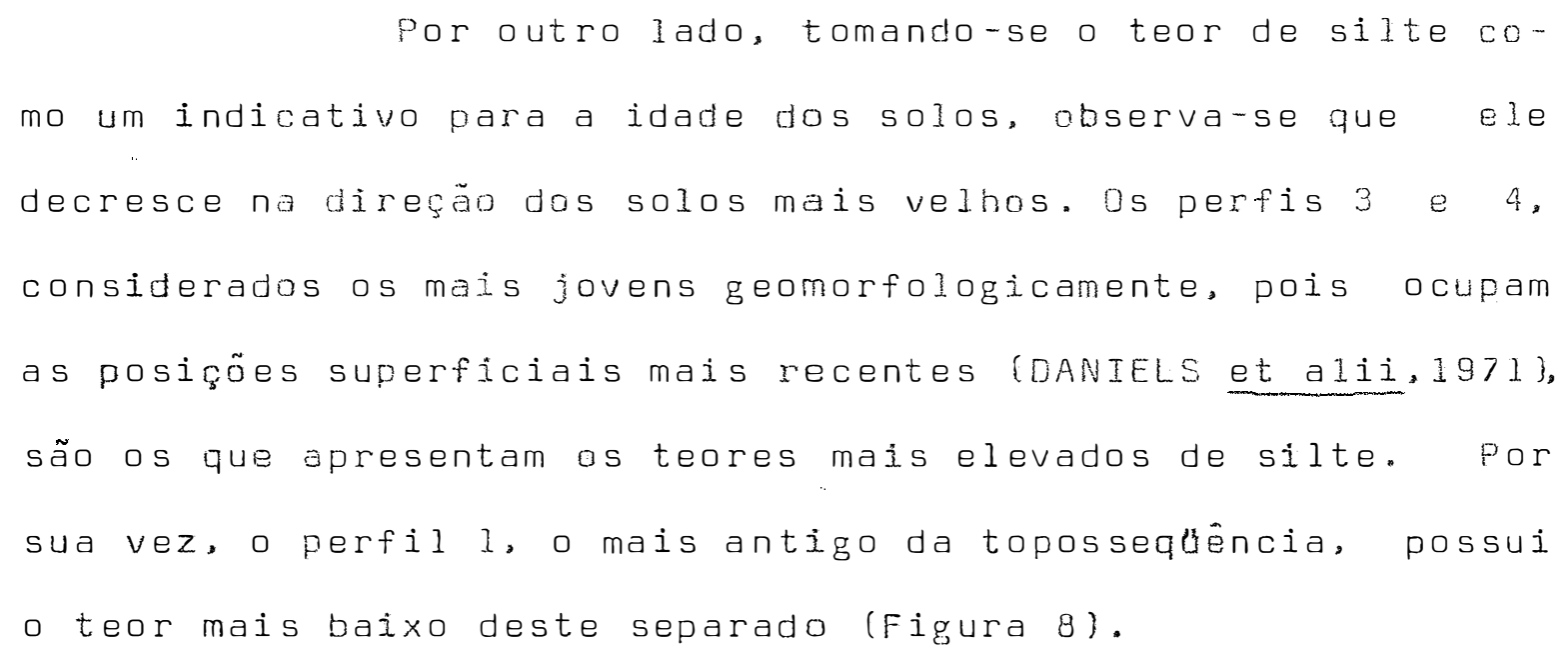

6.2.2 Retenção de ägua

A Figura 9 mostra as relacóes entre as percen 


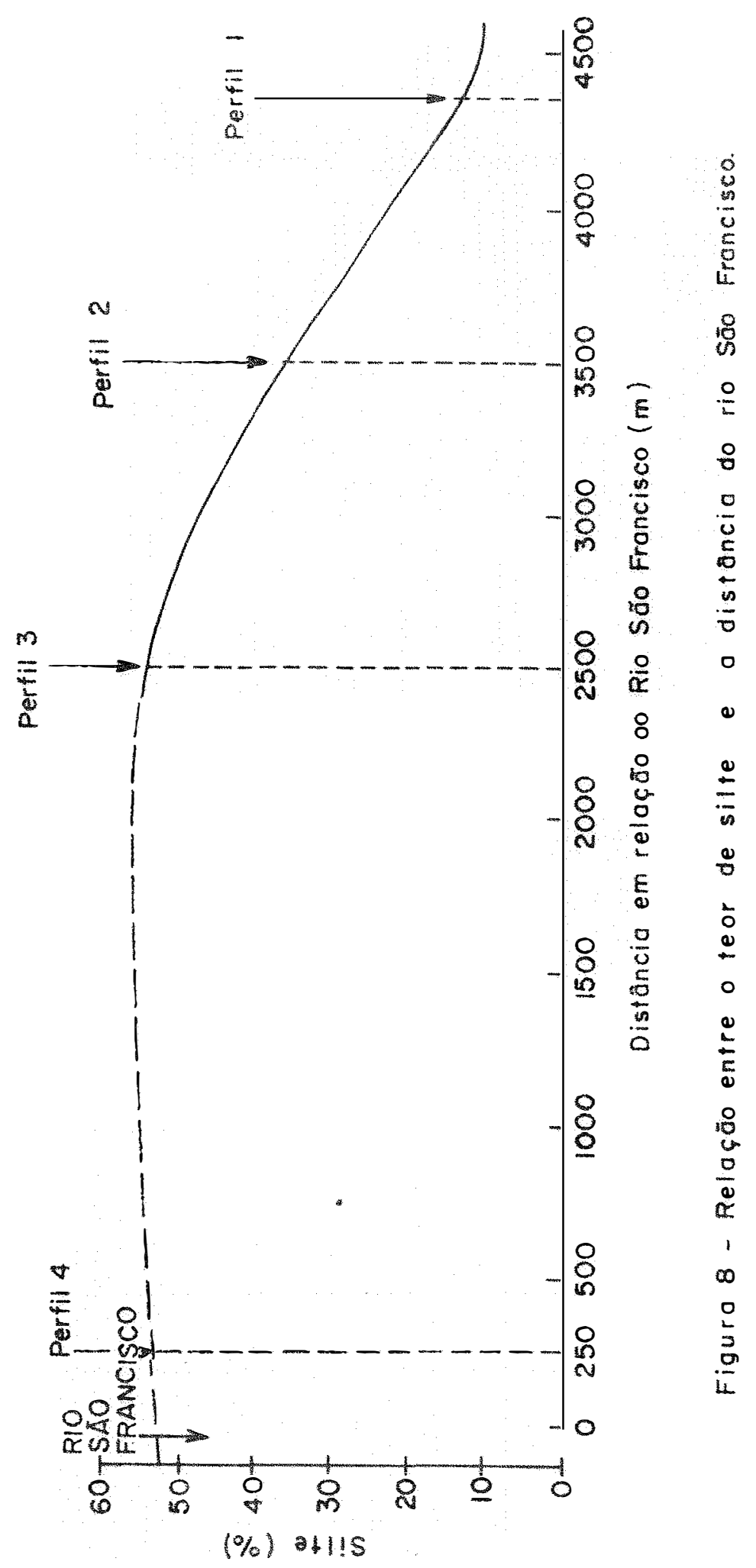


tagens de ägua retidas às tensões de $1 / 3$ e 15 atmosferas na fração menor que 2 mm, umidade residual da terra fina sacada a a moída menor que $0,149 \mathrm{~mm}$ e os teores de argila e carbono orgànico.

Nos perfis 1 e 2, que têm os menores teores de carbono orgânico, a retenção de ägua pelo solo foi influencia da preponderantemente pelo teor de argila. No perfil 1, a ägua retida a 25 atmosferas é a que expressa de modo mais acentuado essa correlação, devido provavelmente à dominància de microporos na estrutura em grumos do último horizonte cole tado. No perfìl. 2, a retenção de água aumentou gradualmente em profundidade. Nenhuma das curvas de retenção acusou a depleÇão dos teores de argila no ültimo horizonte, o que pode ser devido à presença de argila do tipo $2: 1$ nesse horizonte, como constatado por pessoTtI (1978). No perfil 3, tanto o teor de argila quanto o de carbono parecem ter influido na retenção de água, sendo que as curvas de retenção a $1 / 3$ e 15 atmosferas seguem aproximadamente os teores de argila, e a da umidade residual do solo secado ao ar é intermediária entre aquelas e a curva do carbono orgänico. No perfil 4 é marcante a influência dos teores de carbono orgánico na retenção da àgua. principalmente nos dois primeiros horizontes. Entre o $2 \%$ o 3: horizontes, a retenç $\tilde{o}$ de égua pelo solo decresce em menor proporção que os teores de carbono. devido a elevaça dos teo res de argìia. No Gltimo norizonte, a retenção de ägua a l/3 e 15 atmosferas decresce mais acentuadamente que a umidade re sidual do solo secado ao ar, evidenciando o caráter arenoso do 

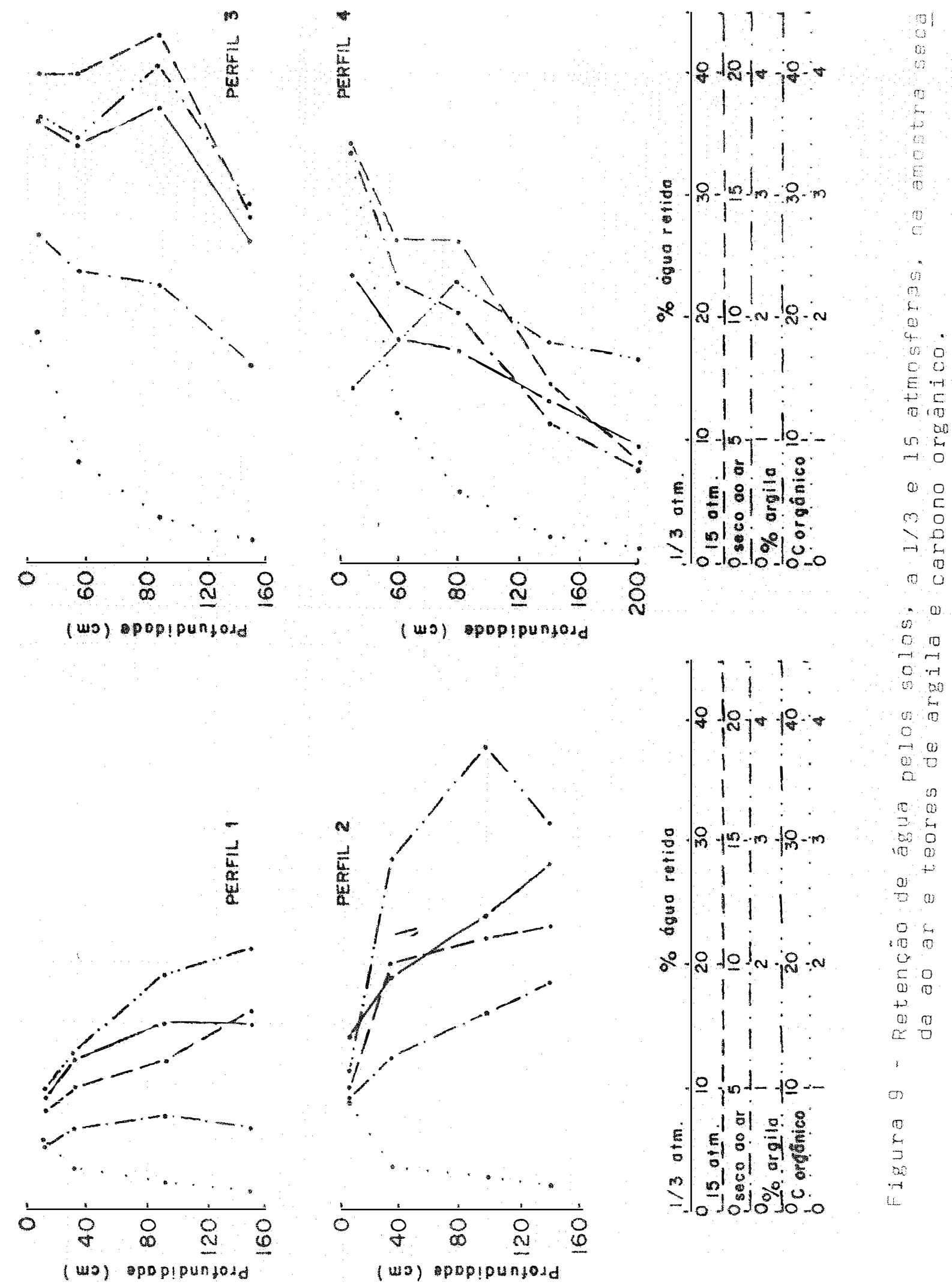
horizonte.

DEMATTE (1975) observa que a retenção de àgua a $1 / 3$ de atmosfera, se determinada em amostras com estrutura indeformada, pode dar valores aproximados da capacídade de cam po dos solos, embora se recontieça que em alguns solos, notadamente nos arenosos, essa medida possa subestimar os valores reais da capacidade de campo. Como se considera a ägua retida a 15 atmosferas inproveitável para as plantas (ponto de murcha permanentel, a água disponível é avaliada subtraindo-seos teores retidos a 15 atmosferas daqueles retidos a $1 / 3$ de at mosfera. Logo, a subestimativa dos valores da capacidade de campo induz ao cálculo de quantidades de água disponível meno res que as reaj.s. Observa ainda que a retenção de água a 1/3 de atmosfera é influenciada principalmente pelos teores de a gila, matéria orgánica, ferro livre e pela estrutura, enquan to a retenção a 15 atmosferas sofre maior influência dos teores e composiçäo mineralógica da argila. Os efeitos destes dois ültimos fatores podem ser notados ainda nos teores de umidade residual ou solo secado ao ar.

Os dados do Quadro 3 permitem verificar que os dois solos com os menores conteúdos de argila (perfis le al) apresentam as quantidades minimas de água disponzel. Porém. no perfil l isto é conseguencia do caráter arenoso desse so10, enquanto no perfil 4 a baixa disponibilidade de ägua se de ve à retenção mais elevada a 15 atmosferas, ligada possivel mente à composição mineralógica da argila deste solo. 
48.

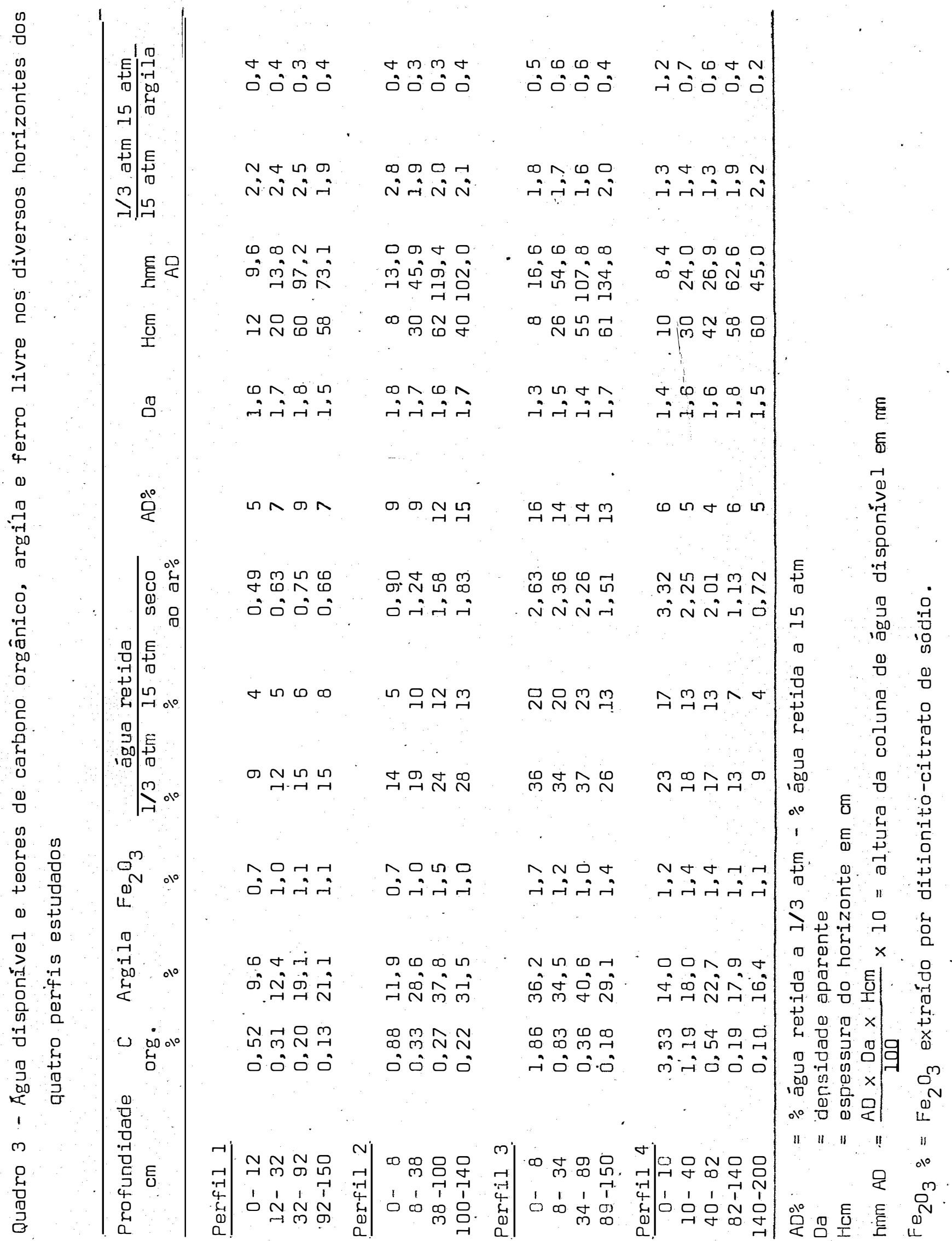


A razão água retida a 15 atmosferas/teor de ar gila nos perfis 1 e 2 mantém-se entre 0,3 e 0,4 , o que ocorre comumente em perfis com características latossólicas (PIERAN TONI, 1971J. Conforme assinalado na discussão dos dados morfológicos, o perfil 2 pode ser considerado um solo de transição, apresentando um horizonte argílico incipiente. A umidade resi dual do solo secado ao ar é sempre menor que $2 \%$ nesses perfis. Nos trés primeiros horizontes dos perfis 3 e 4 , a razão entre água retida a 15 atmosferas e teor de argila é sempre maior que 0,5 e a umidade residual maior que $2 \%$. Considerando os elevados teores de silte desses solos (quadro 2), é provável que este separado tenha contribuido também para a retenção a 15 : atmosferas.

Das considerações de MARCos (1971) deduz-se que discrepãnciasentre o conceito de água disponível e os valores obtidos da diferença entre água retida a 0.33 e 15 atmosferas ou 0,06 e 15 atmosferas devem ser considéradas como indicação de que um dos dois teores de umidade é uma. falsa estimativa; provavelmente o valor que se supõe estimar a capacidade de cam po .

6.2.3. Floculação da argila

O Quadro 4 apresenta os teores de carbono orgâa nico, argila total e dispersa em água, grau de floculação e $\triangle$ PH dos solos estudados. 
Quadro 4 - Argila total e dispersa em água, grau de floculação e $\triangle p H$ na fração $<2 \mathrm{~mm}$

\begin{tabular}{|c|c|c|c|c|c|}
\hline \multirow{2}{*}{$\begin{array}{l}\text { Profundi- } \\
\text { dade } \\
\text { cm }\end{array}$} & \multicolumn{2}{|c|}{ argila $(\%)$} & \multicolumn{2}{|l|}{ grau de } & \multirow{2}{*}{$\begin{array}{l}\mathrm{C} \\
\text { org. } \\
\%\end{array}$} \\
\hline & total & dispersa & flocul. & $\triangle p H$ & \\
\hline \multicolumn{6}{|l|}{ Perfil 1} \\
\hline $0-12$ & 9,6 & 6,2 & 35 & $-0,8$ & 0,52 \\
\hline $12-32$ & 12,4 & 10,2 & 18 & $-0,6$ & 0,31 \\
\hline $32-92$ & 19,1 & 1,6 & 92 & $-0,7$ & 0,20 \\
\hline $92-150+$ & 21,1 & 1,0 & 9.5 & $-0,5$ & 0,13 \\
\hline \multicolumn{6}{|l|}{ Perfil 2} \\
\hline $0-8$ & 11,9 & 6,9 & 42 & $-0,9$ & 0,88 \\
\hline $8-38$ & 28.6 & 1,5 & 95 & $-1,0$ & 0,33 \\
\hline $38-100$ & 37,8 & 1,0 & 97 & $-0,8$ & 0,27 \\
\hline $100-140+$ & 31,5 & 1,0 & 97 & $-0,8$ & 0,22 \\
\hline \multicolumn{6}{|l|}{ Perfil 3} \\
\hline $0-8$ & 36,2 & 21,3 & 41 & $-0,6$ & 1,86 \\
\hline $8-34$ & 34,5 & 2,2 & 94 & $-0,6$ & 0,83 \\
\hline $34-89$ & 40,6 & 1,0 & 98 & $-1,0$ & 0,36 \\
\hline $89-150+$ & 29,1 & 1,0 & 97 & $-1,2$ & 0,18 \\
\hline \multicolumn{6}{|l|}{ Perfil 4} \\
\hline $0-10$ & 14,0 & 10,8 & 23 & $-0,9$ & 3,33 \\
\hline $10-40$ & 18,8 & $12: 2$ & 35 & $-0,8$ & 1,19 \\
\hline $40-82$ & 22,7 & 15,4 & 32 & $-1,0$ & 0,54 \\
\hline $82 \cdots 140$ & 17,9 & 2,4 & 87 & $-1,2$ & 0,19 \\
\hline $140-200+$ & $16: 4$ & 2,8 & 83 & $-0,6$ & 0,10 \\
\hline
\end{tabular}


Os valores de $\Delta$ pH são sempre negativos e, nos perfis 1 e 2, mostram ligeira tendéncia a decrescer, em valores absolutos, com a profundidade. O efeito pode ser devido ao decréscimo do conteúdo de matéria orgánica (VAN RAIJ e PEECH, 1972). Supõe-se que a matéria orgânica, negativamente carregada, fique presa nos sitios positivos das superfícies dos minerais, e que um decréscimo da matéria orgànica em profundiade seja acompanhado por exposição de um ṇúmero crescente de sítios positivos. No último horizonte do perfil $2,0 \triangle$ pH se manteve o mesmo do horizonte suprajacente, provavelmente porque a presença de argilas do tipo 2:i (PESSOTTI, 1978), compensou as cargas positivas oriundas do menor conteúdo de matéria orgánica. Nos perfi.s 3 e 4 , os valores absolutos de $\Lambda$ pH aumentam no $3^{\circ}$ e no $4^{\circ}$ horizontes, embora os teores de car bonọ orgânico decresçam. GILLMAN (1974), trabalhando com um perfil krasnozem (basältico), observou que, quando a mineralo gia da argila mudou de um sistema dominado por goetitae gibbsi. ta para um sistema dominado pela caulinita no horizonte subja cente, o número de cargas posjtivas tornou-se menor. Uma outra explicacão possivel é que, estando esses solos localizados em região de clima sub-úmido e nas superfícies mais recen tés da topossequéncia (DANIELS et aliis. 1971), a precipitação e conseqủentemente a lixiviação não foram suficientes para pro mover um intenso intemperismo que produz cargas positivas Gil.L MAN, 1974].

O grau de floculação da argila ébaixo no perfil l, que apresenta características morfológicas latossólicas. 
Considerando que esse solo tem caráter essencialmente arenoso (Quadro 2), com predominância das frações areia grossa, média e fina, a evidência encontrada é que essas frações atuaram co mo abrasivo no decorrer da agitação por uma noite para determinação da argila natural. Este fato está de acordo com ASHFORD et alii ( 1972 ), que obtiveram percentagens muito maiores de argila dispersa em água ao acrescentar areia aos solos e, inversamente, menores percentagens de argila dispersa em água ao remover parte da areia de solos com elevados conteúdos des te separado. Esses autores observaram que as frações areia mé dia e grossa foram as maís eficientes para promover a dispersão da argila. Por outro lado, os perfis 2 e 3 , que têm os me nores teores de areia, apṛesentam maior grau de floculação de argila nos horizontais B, enquanto o perfil 4, que tem também um horizonte argílico mas com um caráter mais arenoso que os perfis 2 e 3 , apresenta os menores graus de floculação da argila da topossequência.

GILLMAN (197.4) observou argi.la dispersa em ägua; na auséncia de agentes floculantes, sempre que havia um exces so de carga superficial positiva ou negativa. GILLMAN e BELL (1976) observaram que as quantidades de argila dispersa em áğia não podem ser deduzidas pelos valores da carga efetiva, porque esta não se encontra uniformemente distribuída nas héterogêneas amostras de solos. Combinações diferentes de minerais e matéria orgânica necessitam diferentes quantidades de carga para causar dispersão. Segundo esses autores, a mineralogia da argila dispersa apenas em água deionizada é a mesma 
que a da argila dispersa em calgon e soda, indicando que a ar gila natural é uma fração representativa da argila total, embora as análises mineralögicas provavelmente não tenham sido suficientemente exatas para confirmar este fato.

$$
\text { Pelos dados dos Quadros" } 2 \text { e } 4 \text { pode-se notar }
$$

que, nos perfis 1 e 4 , quando a soma das frações areia e silte ultrapassa $80 \%$ da massa do horizonte, a argila dispersa em água está presente a maiores profundidades que hos perfis mais argilosos (perfis 2 e 3 ), o que se coaduna com o provável efeito mecânico das partículas arenosas na díspersão dos agregados de argila, durante o tratamento de agitação no processa mento de análise granulométrica.

\subsection{Características químicas}

6.3.1. Característicás químicas ligadas à fertilida de.

o quadro 5 apresenta as principais caracterís ticas químicas relativas à fertilidade dos solos estudados. De uma maneira geral são solos distróficos, com baixa satura ção de bases, baixa disponibilidade de fósforo, saturação de alumínio maior que 50\% na maioria dos horizontes, em respeito a todos os perfis com exceção do perfil 4. A pequena concen tração de bases no horizonte superior dos perfis 1,2 e 3 se deve à contribuição da matéria orgânica e ạo processo de reci clagem (Buol et alii,. 1973). Apesar de serem solos localizados, 


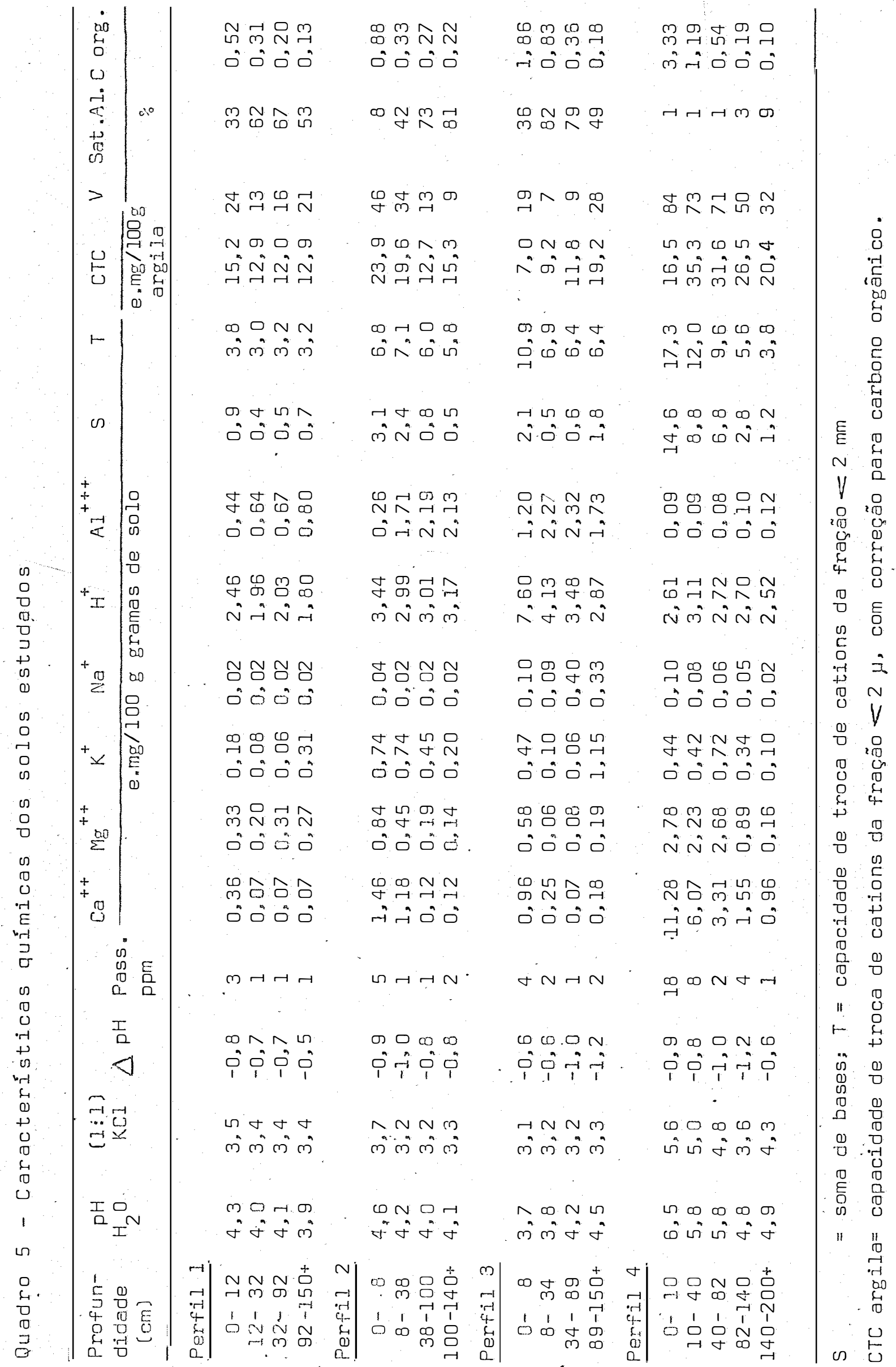


em região climática mais seca e de apresentarem drenagem restringida (caso dos perfis 2 e 3 ), o processo de lixiviação pạ rece estar agindo intensamente nesses solos. Como consequência de tal processo as cargas negativas dos colóides tendem a ficar saturadas com hidrogênio e alumínio. o teor de alumínio. extraível tende a aumentar do perfil l ao 3, concentrando-se nos solos com drenagem deficiente.

0 perfil 4, localizado na superfície mais recente, recebendo continuamente novas contribuições de material, é um solo totalmente diferente dos demais. A saturação de bases é elevada, com predominância de íns de cálcio e mag nésio, cujos teores tendem a decrescer em profundidade. 0 ele vado teor de matéria orgânica nos horizontes superficiais des se solo se deve à ação estabilizadora dos íons bivalentes (BUOL et alii, 1973).

Uma vez que a quantidade de dados relativos aos teores de carbono orgánico, argila e capacidade de troca de cations por perfil é exígua, não é viável a interpretação es tatística desses parâmetros, para averiguação de correlações, como sería desejāvel.

Contudo, verificarse possibilidade de obtenção de estimativa referente à contribuição da fração orgânica (expressa em percentagem de carbono) e da fração argila (cons tituintes minerais) na CTC do material constitutivo dos solos. A consecução dessas juformações pode ser alcançada por recurso a método expedito de determinação gräfica, mediante artifí 
cio de cálculo, proposto por BENNEMA (1966), de aplicação exe quível particularmente no caso dos perfis 1 e 3 , como exposto nas Figuras 10 e 1 l. Já.os dados dos perfis 2 e 4 não se mostram apropriados para a aplicação perfeita desse método (quadro 63 .

Assim, para os perfis 1 e 3 a CTC para 100 gra mas de argila, subtraída a contribuição da matéria orgânicá,é de, respectivamente, 11,4 e 12,0 me, podendó ser estimada em 13,2 me para o perfil 2. Quanto à CTC da matéria orgánica expressa para $1 \%$ de carbono, é de 5,2 me e 3,5 me para os perfis 1 e 3 e estimada em. 5, 5 para o perfil 2 .

Verifica-se pois, que as argilas dos perfis 1 , 2 e 3 são de baixa atividade, traduzida por CTC da ordem de 11-13 me. Em contraposição, no caso do perfil 4 a atividade é alta, sendo a CTC superior a 20 me.

\subsection{2.. Ataque sulfúrico}

0 Quadro 7 apresenta os dados obtidos pelo ata que sulfúrico da terra fina moída menor que $0,149 \mathrm{~mm}$.

Os teores dé sillica, alumínio e ferro aumentam em profundidade nos perfis 1 e 2; nos perfis 3 e 4, aumentam apenas ao longo dos três primeiros horizontes, para decair bruscamente nos horizontes subjacentes. Esses aumentos ou de-créscimos de teores dé sílica, alumínio, e menos estreitamente férro, se subordinam às variações do teor de argilas como 
Quadro 6 - CTC e percentagens de argila e carbono orgànico dos solos éstudados, e valores de CTC e carbono orgâni co para 100 g de argila

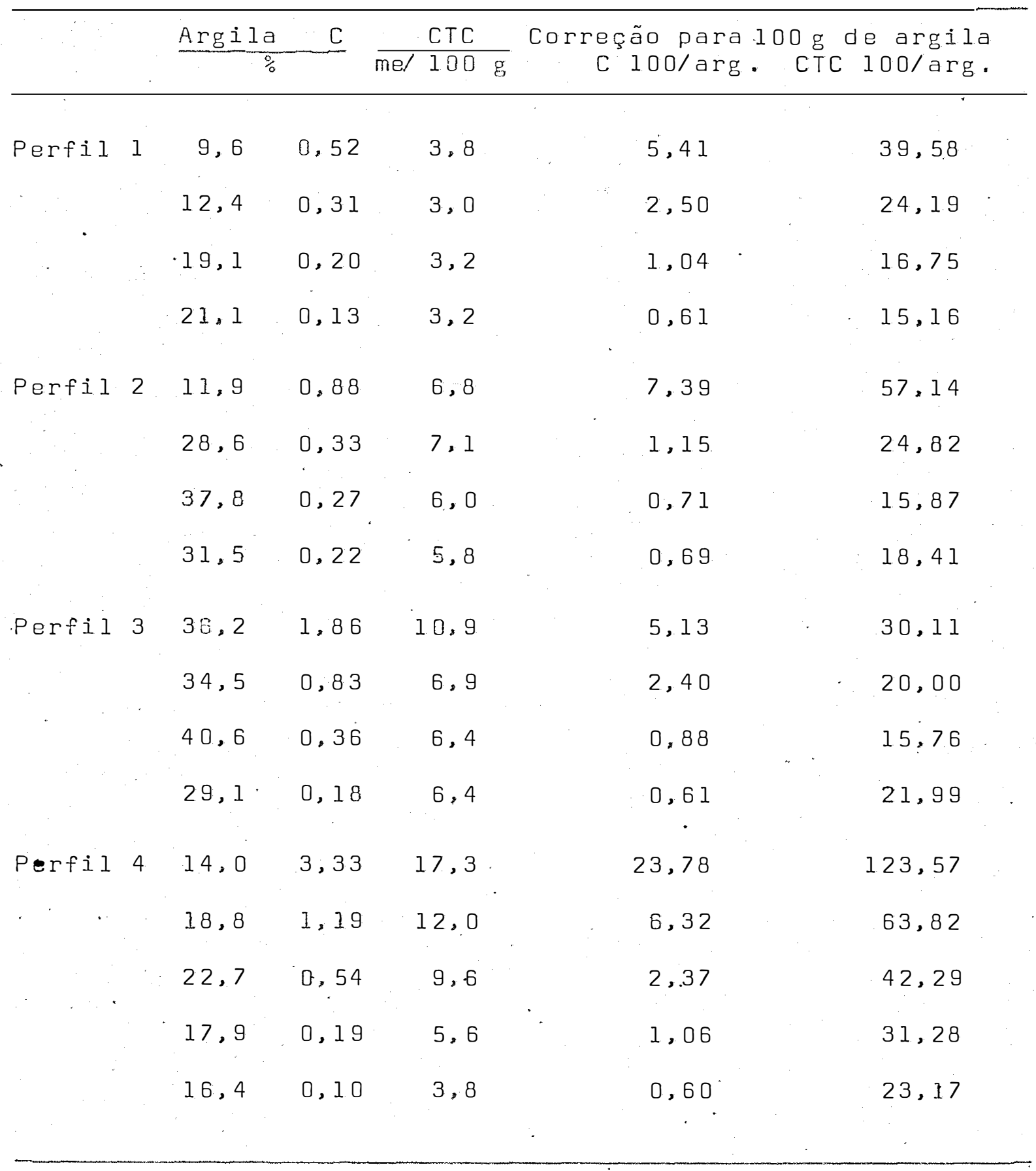




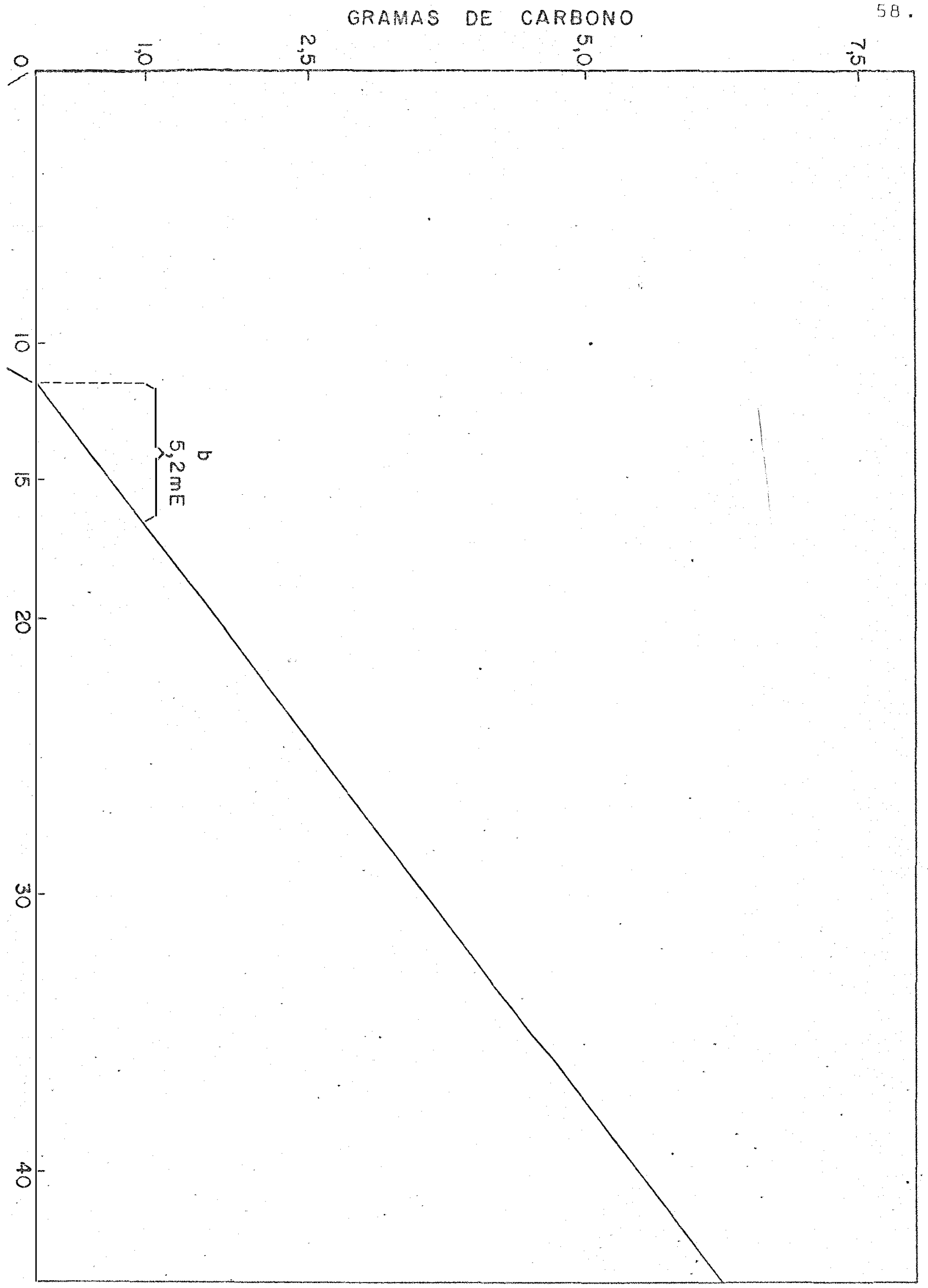

Figura 10 - Cre para l grama de carbono e l de argila no perfil 1 . 


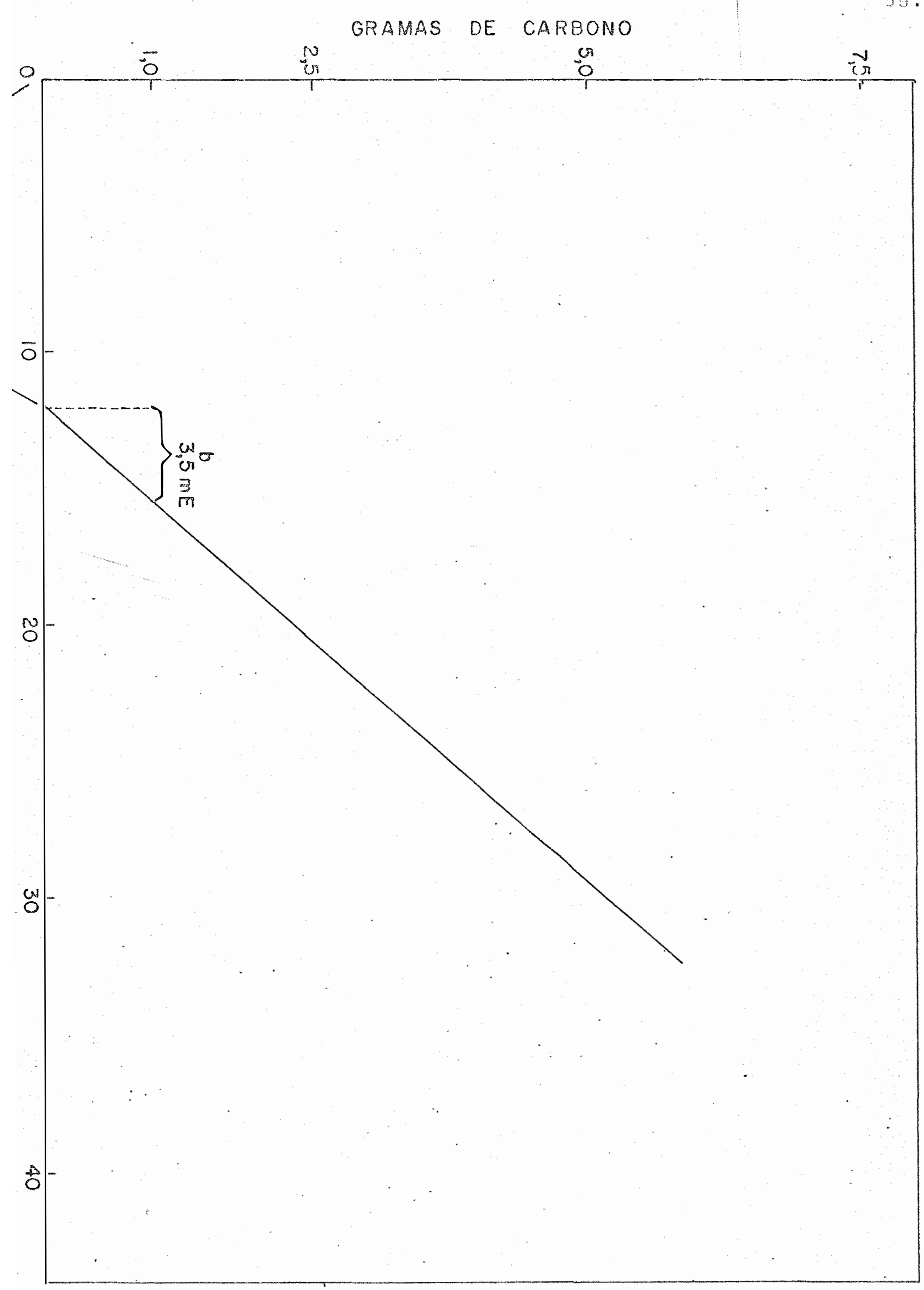

Figura 11. - ctc para l grama de carbono e loo gramas de argja, no perfil 3 . 
seria de se esperar, uma vez que, o tratamento por ácido sulfúrico e carbonato de sódio é feito de molde a atacar a fração argila, podendo eventualmente e de forma pouco intensa afetar outras frações.

Os teores de titánio tendem a aumentar em profundidade nos perfis, harmonicamente aos teores de artila e, por outro lado, tendem a aumentar também da superfície mais antiga para a mais recente. HUTTON (1977) observa que a principal razão para o estudo dos minerais de titânio nos solos (juntamente com o zircônio e o háfnio) é que eles permanecem quando a máioria dos outros.minerais primários já desapareceu em consequência dos processos de intemperismo; pois eles por si mesmo têm pouca ou nentuma influência no sistema de nutrição solo-planta. JACKSON et alii. (1948) e JACKSON e SHERMAN (1953) identificaram uma sequência de intemperismo para minerais das dimensões da argila, e seu estägio mais estável é o $n^{\circ} 13$ - "anatase (também rutilo, ilmenita., leucoxene, corundum, etc.J". Observando os dados ra razão $\mathrm{A}_{2}{ }_{2} \mathrm{O}_{3} / \mathrm{TiO}_{2}$ no perfil l e nos trés primeiros horizontes dos perfis 2 e 3 , nota-se um ligeiro aumento em profundidade. o alumínio poderia en tão parecer mais móvel que o titânio no desenvolvimento des : sés perfis de solos, e isto é refletido na sequencia de intem perismo de JACKSON et alii (1948), de caulinita, gibbsita, he matita, anatase, em ordem de estabilidade crescente. A basedo argumento de CRAIG e LOUGHNAN (1964) é contrária a isto, porque eles preferem considerar o alumínio imóvel sob as condições normais dé intemperismo. No perfil 4, a tendēncia da re- 


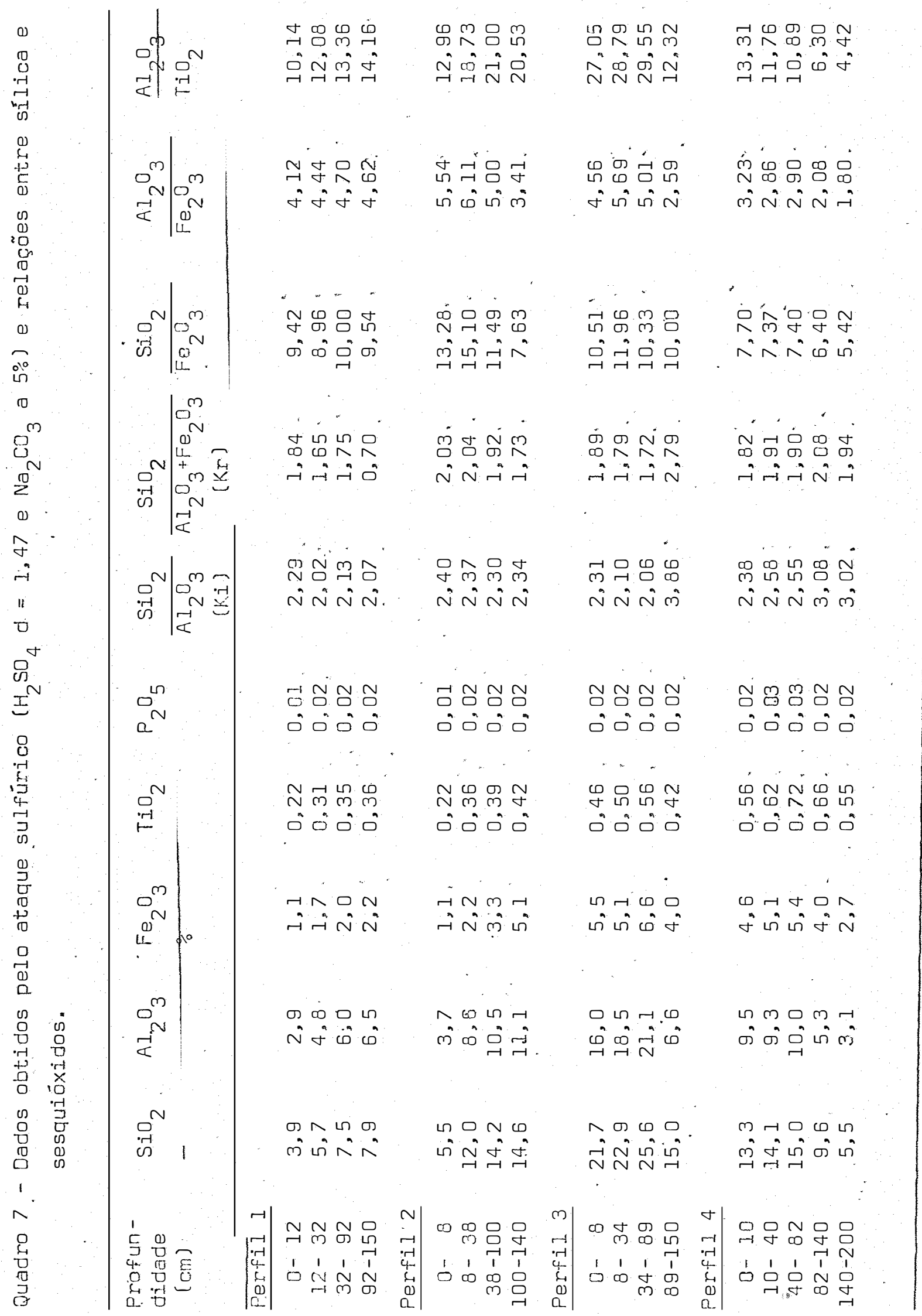


lação $\mathrm{Al}_{2} \mathrm{O}_{3} / \mathrm{TiO}_{2}$ é estreitar-se em profundidade. Por outro la do, observando-se os dados relativos aos teores de $\mathrm{TiO}_{2}$ nos quatro perfis, não é notada influência das condições de redução do perfil 3 sobre as percentagens desse óxido. Os dados do Quadro 7 mostram que, além da tendência a aumentar em profundidade nos perfis e das superfícies mais velhas para as mais jovens, os teores de $\mathrm{TiO}_{2}$ tendem ainda a se contrapor ao índiče ki, isto é, em um mesmo perfil; é frẹquente o índice ki decrescer se os teores de $\mathrm{TiO}_{2}$ se elevarem, e vice-versa. Esses dados, aparentemente discrepantes, podem ter várias explicações. HUTTON (1977) observa que um aspecto de mobilidade do titânio que deve ser considerado é a extensão em que esse elemento faça parte da estrutura das argilas silicatadas encontradas nos solos. Segundo esse autor, cerca de $3 \%$ do titânio poderiam constituir parte da estrutura de micas trioctaedrais como biotita e flogopita, e é comum encontrár-se mais que $1 \%$ de Ti na fração argila de muitos solos. Todavia, é di fícil decidir se o titânio está presente como óxido iivre ou se está preso na camada trioctaédrica da estrutura dos silica tos. No caso dos perfis 3 e 4 estudadosno presente trabalho, se - Ti fizesse parte da rede cristalina dọs minerais de argila desses solos, ós elevados teorés obtidos pelo ataque sulfúrico não indicariam um estágio avançado de intemperismo, senão a influência da composição minerálógica do material de origem silte-argiloso desses solos. Outra explicação, aparentemente mais.razóável e que se aplica ao caso, é que os perfis 3 e.4 fazem parte do terraço de várzea., tv, ou seja, de material de 
origem diferente dos perfis 1 e 2, localizados nos terragos mais elevados e antigos.

Os indices $k i$ e $k r$ tendem a aumentar partindo da superfície mais velha para a mais jovem, se consideradas as médias dos perfis. Refletem também a influência da drenagem réstringida na retenção de alumínjo e ferro lver ki e kr do perfil 3). Já sob drenagem livre, o estágio de intemperismóse expressa ṗela acumulação relativa do ferro sobre a sílica e desta sobre o alumínio (ver ki, $k r$ e razëo $\mathrm{SiO}_{2} / \mathrm{Al}_{2} \mathrm{O}_{3}$ do perfil 4). Segundo SCHWERTMANN e TAYLOR (1977) a reversibilidade da reação de oxidação-redução do férro desempenha um importan te papel no seu comportamento nos solos. Se o oxigênio do soIo se torna deficiente devido ao excesso de ägua, os microrga nismos podem utilizar os íons $\mathrm{Fe}^{3+}$ como um receptor final de letrons para realizar a decomposição oxidativa da matéria orgânica. $0 \mathrm{Fe}^{3+}$ é desse modo reduzido a $\mathrm{Fe}^{2+}$, o qual, sendo g旦 ralmente mais solúvel, acelera a dissolução do óxido. A migra.ção de $\mathrm{Fe}^{2+}$ em solução para zonas de oxiłação induz a re-oxidação e subseqủente reprecipitação. Observam os autores que as reações de redução-sojução.ou quelação-solução e oxidação-precipitação tornam difícil pọsicionar corretamente os óxidos de ferro em uma sequência de intemperismo ou de estabilidade de minerais. Eles participan de, praticamente, todos os estágios de intemperismo e indicam um estágio avançado somente quando fortemente acumulados sob condições aeróbicas - es tägio l. 2 na escala de JACKSON (MONIZ e JACKSON, 1967) com i3 
estāgios de intemperismo.

$$
\begin{aligned}
& \text { 6.3.3. Extrações seletivas de ferro, alumínio e manga } \\
& \text { nês }
\end{aligned}
$$

Os Quadros 8, 9 e 10 apresentam, respectivamen te, os teores de óxidos de ferro, àlumínio e manganês, obtidos pelas extrações desses elementos por ditionito-citrato de sódio (dc) e ditionito-citrato-bicarbonato de sódio (dcb), con siderados óxidos. Iivres; oxalato ácido de amônio na ausência de luz - óxidos amorfos; pirofosfato de sócio - complexos or. gano-metálicos: Teores desses componentes próximos aos totais são representados pelos obtidos no extrato sulfúrico $\quad \mathrm{CH}_{2} \mathrm{SO}_{4}$ $d=1,47\}$

Uma análise rápida dos Quadros citados permite verificar que, na extração com dcb obteve-se, em relação ao Fe principalmente, mas também em relação ao Mn, teores mais baixos que os obtidos com dc nos solos mais velhos e teores muito mais elevados que aqueles nos solos mais jovens. Os teo res de Al foram, de um modo geral, mais baixos que os obtidos com dc.

Segundo os autores do método (MEHRA e JACKSON, 1960) e KUNZE (1965) a extração com dcb precisa ser repetida uma ou duas vezes se a amostra contém originalmente mais d de $5 \%$ de $\mathrm{Fe}_{2} \mathrm{O}_{3}$ extraivei. A evidência encontrada no presente tra. balho é que o fator que torna insuficiente uma ünica extração 
com dcb não é apenas a quantidade de óxidos livres de fe e Mn presentes, mas também a idade do solo. Nos solos com características latossólicas - Oxissolos e mesmo Ultissolos - corres pondentes aos perfis 1 e 2 no presente trabalho, uma só extra ção com dcb não retirou todos os óxidos livres presentes.quan to a isto, um aspecto que talvez desa ser considerado é que, a extráção por dc foi feita com agitação durante 14 horas em agitador de Wagner. Já a extração por dcb se pracessou basicamente mediante a elevação da temperatura a $80^{\circ} \mathrm{C}$. E possível que o efeito mecànico da agitação tenha sido uma das causas que influíram na dispersão dos óxidos livrés de ferro de atividade baixa, isto é, predominantemente cristalinos ou cripto cristalinos.

Quanto ao $A 1$, o de extraiu teores progressivamente mais elevados que o dcb, a partir dos solos mais velhos para os mais jovens. Esta maior eficiência do dc em relação ao dcb pode ser devida a efeito do pH na solubilidade do Al, uma vez que, com o primeiro método a extração é feita a pH 9,0 , enquanto o tamponamento com. bicarbonato de sódio baixa o pH da solução a 8,l, limitando a solubilidade do alumínio. Por ser este elemento anfótero, as extrações com oxalato. de amônio $(\mathrm{pH} 3,0-3,1)$ e pirofosfato de sódio $(\mathrm{pH} 10,0-10,1)$ também foram eficientes.

Para efeito de cálculo e discussão dos resultados, os teores de óxidos livres serão considerados aqueles obtidos pela extração. com dc. porque esse extrator, embora me 
nos eficiente para fornecer os valores absolutos de óxidos li vres de. Fe e Mn, fornece valores relativos aparentemente mais válidos com vistas à distribuição desses óxidos na topossequên cia .

\section{$6.3 \cdot 3 \cdot 1$. Ferro}

De um modo geral, os conteúdos de ferro aumentam da superfície mais velha (perfil l) para as mais jovens, atingindo seu máximo no perfil 3, para decrescer ligeiramente no perfil 4 (quadro 8 ).

No perfil l, além do aumentó em profundidade do ferro extraído pelo ataque sulfürico e do ferro livre, nota-se um aumento gradual nas percentagens de ferro silicatado, que passam de 34 a 50\% ao longo do perfil, acompanhando o aumento dos teores de argila. A razão de atividade do ferro decresce de $58 \%$ no horizonte superficial a. $31 \%$ no último horizonte, indicando proporções mais elevadas de materiais produzidos por intemperismo recente nos horizontes superficiais (MCKEAGUE e Day, ] 366). Os teores de ferro extraídos por piro fosfato são mais elevados no hoṛizonte $B$, o que se reflete em tẹores também mais altos de ferro extraido por oxalato. Esse ligeiro acúmulo de ferro complexado pela matéria orgánicà no horizonte $B$ não tem significação face aos baixos teorés de ferro e carbono orgànico no perfil (CANADA SOIL SURVEY COM'MITTEE, 1973; SOIL SURVEY STAFF, 1975). 
Quadro 8 - Teores de $\mathrm{Fe}_{2} \mathrm{O}_{3}$ extraídos, fração Fe-silicato, razão de atividade do ferro e percentagem da argila

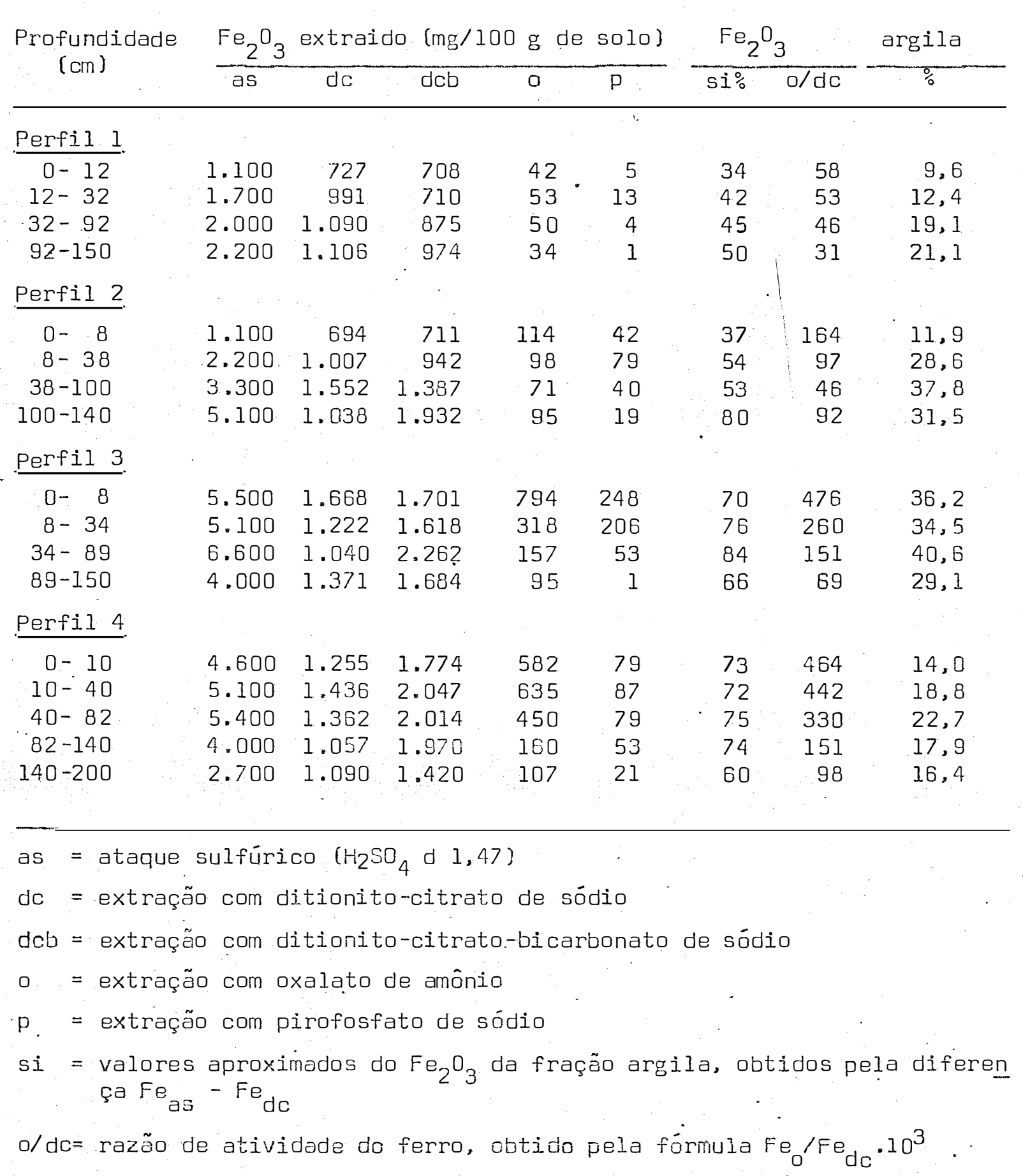


No perfil 4, o mais jovem da topossequência e já sob drenagem livre, os teores de ferro total e organo-complexado são algo mais baixos que os do perfil 3 , porém os teo res de óxidos livres são elevados, havendo regular contribuição dos materiais amorfos. Há uma ligeira acumulação de óxi dos livres, nas suas várias formas, no horizonte Al2. A razão de atividade do ferro nesse perfil indica que o intemperismo vem agindo intensamente. Partindo desse solo em direção aos solos mais velhos, a razão de atividade decresce gradualmente. Neste particular, os dados do Quadro 8 mostram que, embora os teores de ferro organo-complexado sejam elevados sob ambiente redutor, a razão de atividade do ferro não é afetada pela dre nagem restringida e pórtanto pode ser usada como un índice de intemperismo .

Os dados do Quadro 8 sugerem que a transferéncía de óxidosde ferro no perfil parece ter sido um fenómeno importante na gênese dos solos com características latossólicas (perfis 1 e 2), conforme observa MOTHCI (1977) em relação a Latossolos do Planalto Central.

\section{$6 \cdot 3: 3 \cdot 2$. Alumínio}

o alumínio apresenta as mesmas tendências do ferro na topossequéncia quanto aos dados do ataque sulfúrico, porém com teores bem mais elevados. O conteúdo de alumínio li vre é de um modo geral mais baixo quando extraído com dob do que cóm dc, embora este extrator também indique baixos teores 
No perfil 2, o ferro extraído pelo ataque sulfú rico aumenta gradualmente nos três primeiros horizontes e de modo mais acentuado no último horizonte. Esse aumento rião é a companhado pelos teores extraidos por do. mas as extrações por dcb e oxalato acusam a elevação. Este fato permite algumas considerações, por exemplo: a partir desse horizonte, os teores de Fe extraídos por dcb são sempre maiores que aqueles obtidos pela extração com dc, o que está em perfejto acordo com a observação morfológica, segundo a qual as características la tossólicas, na topossequência em estudo, não mais estão presentes a partir desse horizonte. O conteüdo de ferro organo-complexado está mais fortemente expresso no $2^{\circ}$ horizonte(Blt), o que também está de acordo.com a descrição morfológica, que assinala o caráter transicional desse solo.

No perfil 3, os dados do ataque sulfúrico mostram o mais alto conteúdo de ferro, considerado total, da topossequéncia. Nota-se a contribuição dos materiais amorfos, or gânicos e inorgânicos, para os teores. de óxidos livres, principalmente nos horizontes superficiais. Considerando que esse solo tem drenagem restringida, isto está de acordo com TAMURA e JACKSON (1953) que constataram a persisténcia de óxidos livres, notadamente do sistema amorfo, em ambientes redutores. No 3: horizonte há uma acumulação de ferro aponitada pelos dados do ataque sulfürico e pelo dcb, enquanto os teores extraí dos pelo dc são os mais baixos do perfil. Isto pode ser uma indicação da descontinuidade litọógica anteriormente assinalada ṇesse horizonte. 
Quadro 9 - Teores de $\mathrm{Al}_{2} \mathrm{O}_{3}$ extraídos, fração Al-silicato, razão de ativi.dade do alumínio e percentagem da argila.

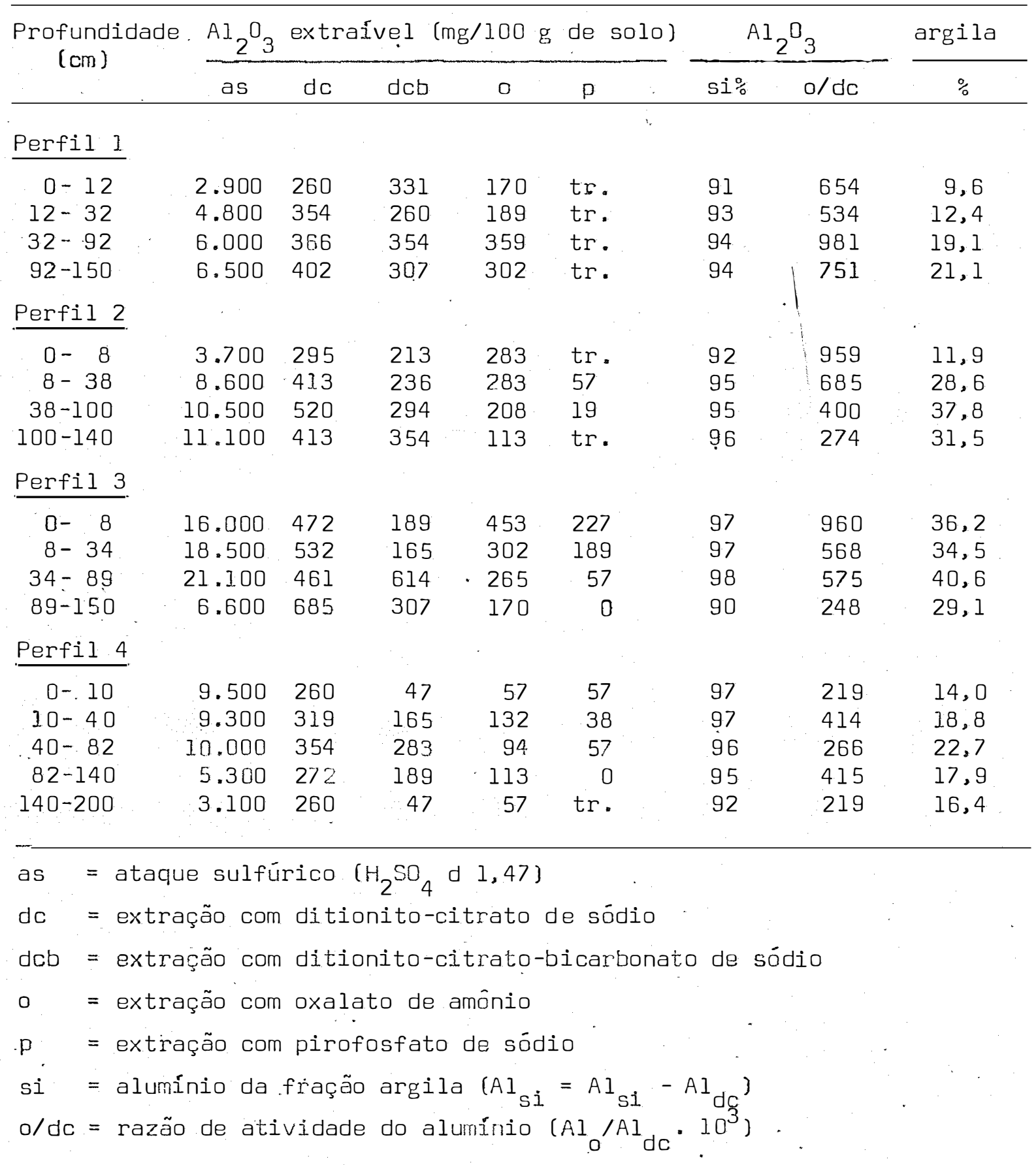


de alumínio livre (Quadro 9). Os teores desta fração são apro ximados no solo mais velho (perfil I) e no solo mais jovem (per fil 4) sob influência de drenagem boa, e se elevam nos perfis 2 e 3 que têm drenagem sucessivamente mais restringida. A fra ção do alumínio retida na estrutura dos minerais de argila é sempre maior que $90 \%$ dos teores totais, sendo algo mais eleva da nos trés primeiros horizontes dos perfis 3 e 4 . A razão de atividade do alumínio no perfil l indica que o intemperismo vem atuando nesse solo, havendo apenas traços de compostos or gânicos de alumínio no perfil. Já nos perfis 2 e 3 a elevada razão de atividade do alumínio se deve à influéncia da drenagem restringida, uma vez que os teores de alumínio extraído por oxalato são os mais elevados da topossequência. A menor razão de atividade do alumínio é constadada no perfil 4, situ ado na superfíciemais recente da catena. Todavia, isto pode refletir mais uma vez a influência da drenagem sobre o compor tamento do alumínio nos solos, como assimalado quanto aos teo res de óxidos livres, e então não é possivel considerar o alu mánio como um índice de intemperismo.

\section{$6 \cdot 3 \cdot 3 \cdot 3$. Manganês.}

Os dados obtidos para manganês não permitẹm que seus teores sejam discutidos da mesma forma que os teores de ferro e de alumínio. No entanto; algumas considerações pode- rão ser feitas. 
O manganês comportou-se de modo semelhanté ao ferro, quanto à extração de óxidos livres: do extraiu maiores quantidades que dcb nos solos mais velhos, e menores quantida des que este extrator no solo mais jovem (perfil 4). Porém, di verentemente do que foi constatado quanto ao ferro e ao alumí nio, os teores de óxidos livres de manganês são mínimos nos horizontes $B$ e C do perfil 3, sob influência de drenagem restringida. Isto está de acordo com MBORE (1973) que, usando dcb como extrator (MEHRA e JACKSON, 1960), encontrou teores mais baixos de óxidos livres de manganês em horizontes gleizados. Cabe observar que más condições de aeração não são favoráveis ao desenvolvimento de microrganismos que atuam sobre os compostos de manganés.

Os dados do Quadro 10 mostram que a manganēs está presente predominantemente sob a forma de óxidos livres nos horizontes superficiais dos perfis 2 e 3 , e em todo o per fil 4, excetuado o horizonte superficial. Neste último perfil, está quase totalmente no estado amorfo, com regular contribui ção dos compostos organo-complexados. Quanto aos teores mais elevados de manganês nos horizontes superficiais, é válida a observação de BLUME e SCHWERTMANN (1969): pelo. fato de ser es te elemento um nutriente para as plantas e elevada proporção do manganês total participar do biocíclo, deve ser esperada a sua acumulação pela vegétação.

A maior concentração de manganês no perfill 4 pode ser devida. a diversos fatores, entre os quais: 
Quadro 10 - Teores de $\mathrm{Mn}_{2} \mathrm{O}_{3}$ extraídos e percentagens de carbono orgânico dos solos estudados.

\begin{tabular}{|c|c|c|c|c|c|c|}
\hline \multirow{2}{*}{$\begin{array}{l}\text { Profundidade } \\
\quad(\mathrm{cm})\end{array}$} & \multicolumn{5}{|c|}{$\mathrm{Mn}_{2} \mathrm{O}_{3}$ extraído (mg/l00 g de solo) } & \multirow{2}{*}{$\frac{\text { C org } \cdot}{\%}$} \\
\hline & as & $d c$ & dcb & 0 & $p$ & \\
\hline \multicolumn{7}{|l|}{ Perfil 1.} \\
\hline $0-12$ & 5,58 & 3.51 & 2,84 & 2,59 & 1,01 & 0,52 \\
\hline $12-32$ & 5,22 & 2,52 & 1,62 & 1,01 & 1,01 & 0,31 \\
\hline $32-.92$ & 5,22 & 2,34 & 2,68 & 0,58 & 1,01 & 0,20 \\
\hline $92-150$ & 5,22 & 2,52 & 1,62 & 0,14 & 1,01 & 0,13 \\
\hline
\end{tabular}

Perfil 2

$\begin{array}{rrrrrrr}0-8 & 13,32 & 16,20 & 15,66 & 14,11 & 3,74 & 0,88 \\ 8-38 & 7,20 & 4,95 & 4,11 & 2,59 & 1,30 & 0,33 \\ 38-100 & 6,12 & 2,79 & 2,68 & 1,0,1 & 1,30 & 0,27 \\ 100-140 & 6,66 & 2,52 & 2,16 & 0,58 & 1,01 & 0,22\end{array}$

Perfil 3

$\begin{array}{rrrrrrr}0-8 & 13,32 & 10,89 & 2,76 & 9,07 & 3,74 & 1,86 \\ 8-34 & 8,10 & 2,07 & 1,62 & 1,01 & 1,01 & 0,83 \\ 34-89 & 7,56 & 1,62 & 1,26 & 1,30 & 1,01 & 0,36 \\ 89-150 & 6,66 & 2,07 & 0,72 & 0,14 & 1,01 & 0,18\end{array}$

Perfil 4

\begin{tabular}{rrrrrrr}
$0-10$ & 75,60 & 61,83 & 64,26 & 67,82 & 18,43 & 3,33 \\
$10-40$ & 69,30 & 64,17 & 73,98 & 67,82 & 9,07 & 1,19 \\
$40-82$ & 66,60 & 59,40 & 67,86 & 56,16 & 4,90 & 0,54 \\
$82-140$ & 30,24 & 32,67 & 41,22 & 25,20 & 3,31 & 0,19 \\
$140-200$ & 21,24 & 20,61 & 35,10 & 16,42 & 1,73 & 0,10 \\
\hline
\end{tabular}

as = ataque sulfúrico $\left(\mathrm{H}_{2} \mathrm{SO}_{4} d \mathrm{l}, 47\right)$

$d c=$ extração com ditionito-citrato de sódio

dcb = extraçẽo com ditionito-citrato-bicarbonató de sódio

o = extração com oxalato de amōnio

$P$ = extração com pirofosfato de sódio. 
- Natureza do material de origem desse solo, constituído por sedimentos argilo-siltosos fluviais. Neste particular, ROSS et alii (1976) estudando várias ordens de solos de Indiana (E.U.A.), observaram que os dois solos (Ginat e Weinbach) que não apresentavam evidência de qualquer forma cristalina de man ganês, desenvolveram-se em terraços de deposição ao longo do rio Ohio.

- Conteúdos mais elevados de matéria orgánica proporcịonados pela floresta ribeirinha e, principalmente, pelos teores mais elevados de cálcio e magnésio (Quadro 5). Esta condição favorece também a atividade de microrganismos, que está morfologi camente evidenciada por galerias biológicas preenchidas com ma terial preto nos dois primeiros horizontes do perfil.

- Possível acumulação do manganés por efeito da evapotranspiração. DROSDOFF e NIKIFOROFF (1940) sugeriram que à medida em que a água é evaporada ou tomada pelas plantas, a solução do solo fica mais rica em Mn, e essa solução vai ocupando poros sucessivamente menores.

6.4. Classificação dos solos

Os dados obtidos para o perfil l permitiram a caracterização de um epipedon ócrico (SOIL SURVÉY STAFF, 1975) ou horizonte A moderado pelos conceitos do sistema brasileiro de classificação (BRASIL, 1973): como horizonte diagnóstico de subsuperfície ficou caracterizada o óxico ou o B latossólico. 
As caracteristicas desse solo, principalmente as morfológicas, permitiram o enquadramento como Latossolo Vermelho-Amarelo A moderado. Os dados granulométricos e químicos completaram a classificação: Latossolo Vermelho-Amarelo Alico A moderado tex tura média. Pelos conceitos americanos e ao nível de subgrupo o solo pode ser enquadrado como Typic Haplorthox.

o solo representado pelo perfil 2, localizado em uma cota menos elevada que o perfil 1; é aparentemente latossólico, devido principalmente às caractéristicas de cor e profundidade. Entretanto, um exame mais cuidadoso evidenciou a presença de um epipedon ócrico (devido apenas à pequena espessura\} ou horizonte A moderado, um horizonte argílico ou B textural pouco desenvolvido e um horizonte óxico ou latossóli co. Dada principalmente a presença dos horizontes B textural e B latossólico, a classificação desse solo pode ser a seguin te: Podzólico Vermelho-Amarelo Alico latossólico plíntico A moderado textura média/argilosa. Pelos conceitos da classificação americana, pode ser a seguinte: Plinthic Paleustult.

0. perfil 3, situado na superfície fisiográfica imediatamente inferior à do perfil 2, representa um solo que morfologicamente difere dos demais. Devido principalmente às características morfológicas, o epipedon pode ser classificado como ócrico ou horizonte A moderado e o horizonte de subsu perfície como argílico ou B textural. Pelos conceitos do sis- tema brasileiro de classificação esse solo pode ser enquadra: do como Laterita Hidromórfica argila de atividade baixa Alica 
A moderado textura siltosa/argilosa. Pelo sistema americano pode ser classificado como Oxic Plinthaquult.

Apesar de, no sistema brasileiro de classifica ção de solos, ser dada bastante importância para o incremento de argila na definição do horizonte B textural, no casodo per fil 3 este horizonte foi evidenciado mais pela presença de cu tan iluvial. A primeira camada, no caso deste solo, é conside rada como sendo de deposição recente, mascarando com isso a di ferença textural. O segundo horizonte, por sua vez, já apresenta características morfológicas de B, àssim como custans i luviais em apreciável quantidade.

Finalmente o.perfil 4, localizado próximoàmar gem do rio são Francisco, possui um epipedon mólico ou horizonte A chernozêmico e um horizonte de subsuperfície argílico ou B textural. Pelo sistema brasileiro a designação que mais se aproxima desse solo é Brunizem Avermelhado textura mé dia e pela designação americana, Udic Paleustoll. o problema da classificação deste solo, tanto no sistema brasileiro como no americano, diz respeito a ocorrência de horizonte argílico aliado à posição que. o solo ocupa na paisagem. o tema"paleo". do sistema americạno, se refere à distribuição de argila. em profundidade e também tem um significado de "velho", "antigo". Como este salo está na posição de uma pestana próximo ao rio São Francisco, isto pode significar, pelo menos em uma análise superficial, que ele foi formado recentemente. Entretanto, a ocorrência de horizonte argílico em um solo é dependente do. 
tempo (BUOL et alii, 1973). Estudos mais profundos, tanto geo morfológicos como pedológicos, devem ser conduzidos para elucidar tal problema.

6.5. Relação entre os solos e a paisagem.

o conjunto dos dados morfológicos, físicos e químicos dos solos estudados, relacionado com as diversas posições ocupadas no relevo, possibilita a verifiçação de que as propriedades dos.solos são funções principalmente dessa posição e da drenagem, confirmändo as observaçọes, em especial as de NYE (1954) e DANIELS (1971).

A região estudada foi retrabalhada pelo rio São Francisco, formando o nível pedimentar Pdl de PENTEAdo(1972), conforme mostrado na Figura 3. Neste material pedimentar e através de retomadas erosivas, o rio formou os terraços tl, em nível mais elevado, sede dos perfis l e 2 , e o terraço de vár zea, tv, sede dos perfis 3 e 4 .

0 perfil l, situado na posição mais elevada da área do estudo, está praticamente em uma superficie mais está vel. O material de origem é relativamente homogêneo, e o solo é espesso e bem drenado. Em consequéncia, os processos pedoge néticos, principalmente os de lixiviação (ver Quadro 5) e de dessilicatização (ver CTC da argila na Figura 10̣), têm ağido livremente, levando o solo a apresentar um perfil bem intempe. rizado. A pequena concentração de bases na superfície desse perfil se deve ao processo de reciclagem (BUOL et alii, 1973): 
A estrutura assume caráter grumoso, com muitos poros, muito fraca e sem evidéncias de iluviação, levando o solo a apresen tar um perfil latossólico.

B perfil 2, correlativo com superfície geomórfica ulterior àquela em que se desenvolveu o perfil l, já. pos sui um grau de estrutura com alguma expressão. o processo de lessivagem já se fez presente, evidenciado pela formação de um horizorite argílico incipiente. o processo de lixiviação não é tão acentuado quanto no perfil anterior, apesar de a drena gem ainda ser boa. O perfil apresenta o aspecto de um solo de transição, e por isso classificado como Podzólico Vermelho-A marelo latossólico.

O perfil 3; localizado na vārzea, com drenagem restringida, e mais jovem que o perfil 2, possui um horizonte argílico mais evoluído. Devido às características de drenagem, - grau de estrutura se acentua, porém a quantidade de cutan. iluvial é pequena (JIMENEZ, 1978), sendo entretanto suficien.te para possibilitar a identificação de um horizonte argílico. O intemperismo neste caso decresce de intensidade. Apesar da diferença textural ser pequena, é preciso levar em considera ção que o primeiro horizonte déste solo deve ser constituído por material recente.

Finalmente o perfil 4, localizado em uma pesta na próximo ao rio São francisco, sendo, portanto, mais jovem que os outros solos, possui drenagem mais livre que o solo a terior: Consequentemente, o horizontẹ argílico, assim como as 
características de textura e estrutura, estão melhor evidenci ados neste caso. Como é um solo considerado formado por materiais holocênicos, a lixiviação não é de carāter muito acentu ado (Quadro 5) e o processo de adição parece ser de grande im portáncia. A lessivagem, evidenciada pela presença de horizon te argílico neste perfil, parece ter uma influência marcante neste solo, e ela é dependente do tempo (BIRKELAND, 1974).Em outrás palavras, o horizonte argílico tem sido constatado nor malmente em superfícies mais velhas, instáveis e de material anterior ao Holoceno (BUOL et alii, 1973), contrariando em par te o que foi observado neste solo.

Pela eliminação do perfil 3 , que possui drenagem deficiente, o exame dos demais solos evidencia que as características do horizonte argílico se acentuam desde os solos mais velhos aos mais jovens. o horizonte óxico, neste caso, ocorre na superfície mais velha, enquanto o horizonte arí lico ocorre nas superfícies mais jovens.

Com base nas informações de PENTEADO (1972), as idades dos solos podem ser colocadas de acordo com a idade das superfícies (DANIELS et alii, 1971), atravēs de correlação re lativà. O perfil l, o mais antigo da topossequência, está referido ao Pleistoceno Médio. o perfil 2 se formou em uma superficie mais recente que a anterior, provavelmente em outro evento, talvez referido ao Pleistoceno Superior. Finalmente; os perfis 3 e 4 desenvolveram-se em material mais recente,tal vez no Holoceno, devido à proximidade do rio São Francisco. 
7. CONClusúes

- Existe uma relação entre os solos e as posições que eles ocupam no relevo, sendo que o solo mais intempe rizado está localizado na superfície mais velha, enquanto os menos intemperizados ocupam as superfícies mais jovens.

- Todos os solos estudados são provenientes de material retrabalhado.

- As características morfológicas, físicas e químicas refletem a posição de ocorréncia dos solos. o horizon te óxico ocorre na superfícié mais velha, enquanto os argíli cos ocorrem nas superficies mais jovens.

- E possível que a ação mecãnica da fração areia durante a agitação da amostra tenha contribuido para dispersar parte dos agregados de argila, levando à subestimação do grau de floculação da argila no perfil 1.

- A capacidade de troca catiónica está mais re lacioniada com o teor de matéria orgànica nos perfis 1,2 e 3 , 
devido a baixa atividade da argila. No perfil 4, a argila de atividade alta contribui em maior grau para a capacidade de troca de cations.

- De acordo com o processo de intemperismo ou de evolução dos solos e partindo dos solos mais jovens para os mais velhos, a sequência encontrada é: Mollissolo, Ultisso 10, Oxissolo.

- As razões de atividade do ferro decrescem ao longo dos perfis e também das superfícies mais jovens para as mais velhas, permitindo que sejam consideradas como índices de intemperismo.

- O alumínio é altamente influenciado pela dre nagem, e suas razões de atividade não podem ser usadas como indices de intemperismo.

- Os conteúdos de manganês, em suas várias for mas, estão sob a influência de diversos fatores, entre os quais o material de origem, teores de matéria orgánica, idade do so lo e drenagem, não podendo dar indicações sobre o intemperis mo dos solos.

- Estudos mais detalhados devem ser conduzidos para melhor esclarecer a ocorrência de horizonte argílico no perfil 4 . 
82.

\section{SUMMARY}

The morphological, physical and chemical characteristics of four pedons located in a catenary esquence of the Jequitai Region, in the State of Minas Gerais, Brazil,were studied. Pedon 1, a Red-Yellow Latosol Alic moderate A horizon loamy (Typic Haplorthox) is located in the oldest surface; pedon 2, a Red-Yellow Podzolic Alic latosolic plinthic (Plinthic Paleustult is located in a surface lower than the previsious one; pedon 3 , a Ground-Water Laterite Alic low clay activity moderate A horizon silty/clayey (Oxic Plinthaquult), the only poorly drained soil in the toposequence, is located in the bottomland, and finally, pedon 4, a Reddish Brunizem loamy (Udic Paleustoll), the youngest soil in the toposequence, is located in a natural levee along the São franciscọ river.

The data indicated that a rellationship does - exist between the soils and their position in the landscape, being the more weathered soils (pedons 1 and 2 ) located in 
the uplands, while the less weathered ones (pedons 3 and 4 ) are located in the lowlands. Oxic horizon occurs in the older surface, and argillic horizon sin the more recent surfaces.

The occurrence of argillic horizon in pedon 4 , in Holocenic material near the märgin of the são Francisco ri ver, could be better explained by more detailed geomorphologi cal and pedological studies.

There is a relationship between the classification of soils by the American System of Classification and the stage of evolution of the soils as related to the sequence of geomorphic surfaces, so that, from the youngest to the oldest soils - pedons 4 to 1 - the sequence found is:Mollisol, Ultisol, Oxisol.

In order to study the form of occurrence of free oxides in the soils of the toposequence, iron, aluminum and manganese were extracted by sulfuric acid, sodium dithionite-citrate, sodium dithionite-citrate-bicarbonate, acid amọ nium oxalate and sodium pyrophosphate. Sodium dithionite - citrate-bicarbonate seems to be a better extractor for iron and manganese, but as for the Oxisol and the Ultisol located in the contiguous geomorphic surface, one single extraction was not sufficient to remove all free oxides present. Sodium dithionite-citrate was, in general, more efficient in the extra ction of free aluminum oxides. This extractor was used to estimate the activity ratio, both of aluminum and iron, although the absolute values of the latter might be lower, be- 
cause the dithionite-citrate seems to provide more valid rela tive data in regard to the distribution of free oxides in the toposequence.

It was verified that the activity ratio of iron may be used as an index of weathering, although the organiccomplexed iron values suffer the influence of both age and drainage of the soil.

The organic-complexed aluminum shows, more strongly than iron, the influence of drainage and age of the soil. The great contribution of the amorphous fraction in the total of free oxides under reduction conditions prevents the aluminum activity ratio to be considered as an index of weathering.

Under reduction conditions, the manganese beha ves in an opposite manner than iron and aluminum, presenting minimum values of free oxides. In the younger soils it is totally contained in the amorphous fraction. From this soil to the older soils, the sulfuric acid provides manganese volues higher than the ones obtained from other extractors. 
ASHFORD, E.M., L.G.SHIELDS e J.V. OREW, 1972. Influence of sand on the amount of water-dispersible clay in soil. Soil. Science Society of America Proceedings, Madison, 36 (5):848849.

BASCOMB, C.L. 1968. Distribution of pyrophosphate-extracta ble iron and organic carbon in soils of various groups. Journal of Soil Science, Edinburgh, 19(2):251-268.

BATES, T.F. 1959. Rock weathering and clay formation in Hawaij. Mineral Industry State College of Pensylvania, Pensylvania (29): $1-6$.

BENNEMA, J. e M.N. CAMARGO. 1964. Segundo esboço parcial de. classificação de solos brasileiros; subsídios à VI. Reunião Técnica de Levantamentos de Solos. Divisão de Pedologia e Fertilidade do Solo. Rio de Janeiro, 50p. 
BENNEMA, J. 1966.Classification of Brazilian Soils. Report to the Government of Brazil. Rome, Food and Agriculture Organization of the United Nations, 83p.

BILZI, A.F. e E.J. CIOLKOSZ. 1977a. Time as a factor in the genesis of four soils developed in recent alluvium in pensylvania. Soil Science Society of America Journal.Madison; 41 (1): $122-127$.

- 1977b. A field morphology rate for evaluating pedological development. Soil Science, Baltimore, $124(1): 45-48$.

BIRRELANO, P.W. 1974. Pedology, weathering and geomorphological research. Nes York, Oxford Press. 6l9p.

BLAKE, G.R. 1965. Particle density. Bulk density. In: C. A. BLACK (ed.). Methods of soil analysis. Madison, wisc) American Society of Agronomy: p.371-390. (Agronomy, 9).

BLUME-H.P. e U. SCHWERTMANN. 1969. Genetic evaluation of pro file distribution of aluminum, iron and manganese oxides. Soil Science Society of America Proceedings, Madison, 33 (3) : $338-444$.

BRAJNIKOV, B. 1950. Os tráços estruturais do vale do são Fran cisco: Boletim Geogräfico, Rio de Janeiro, IBGE. (93):10921093.

BRASIL. Departamento Nacional de Pesquisa Agropecuária. Divisão de Pesquisa Pedólógica. 1973. Levantamentó exploratório. reconhecimento de solos do Estado de Pernambuco. Recife, $2 v$ (Boletim Técnico, 26 ). 
BUOL, S.W., S.D. HOLE e R.J. MCCRAKEN 1973. Soil genesis and. classification. Ames, Iowa State University Press. 360p.

CANADA. Department of Agriculture. Soil Surney Committee.1978 The Canadian system of soil classification. Ottawa, I64p. (Can. Dep. Agric. Publ. 1646).

CRAIG, O.C. e F.C. LOUGHNAN. 1964. Geochemical and mineralogi cal transformation accompanying the weaghering of basicvol canic rocks from South Wales. Australian Journal of. Soil. Research: Melbourne, 2:218-234.

DANIELS, R.B., E.E. GABLE e J.G. CADY, 1971. The relation between geomorphology and soil morphology and genesis. Advan. ces in Agronomy. New York, 23: 51-89.

DEMATTE, J.L.I. 1975. Characteristics and classification of. a toposequence of soils near Piracicaba, Brazil. Columbus, Ohio Sate University, (Ph.D. Thesis).

DIXEY, F. 1955. Erosion surfaces in Africa: some considerations on age and origin. Proceedings, Geological Society of South Africa. Johannesburgh, 58:265-280.

DROSDDFF, M. e C.C. NIKIFDRDFF, 1940. Iron-manganese concret tions in Dayton Soils. Soil Science. Baltimore, 49:333-345. ESTADOS UNIDOS. Soil Conservation Service. Soil Surney staff. 1975. Soil Taxonomy. A basic system of soil classification. for making and interpreting soil surveys. Washington, D.C. USDA, 154p. (Agricultire Hand book, 436)'. 
FIELDS, M. e L.O. SWINOALE. 1954. Chemical weathering of sili cates in soil formation. New Zealand Journal of Science and Technology. Wellington, 36B:140-154.

FREITAS, R.0. 1951. Ensaio sobre o relevo tectónico do Brasil. Revista Brasileira de Geografía. Rio de Janeiro, 13(2):171222 .

GILLMAN, G.P. 1974. The influence of net charge on water-dispersible clay and sorbed sulphate. Australian Journal of Soil Research. Melbourne, 12:173-176.

GILLMAN, G.P. ẹ L.C. BELL: 1976. Surface charges characteristics of six weathered soils from tropical North Queensland. Australian Journal of Soil Research. Melbourne, 14:351-360.

HOLMGREN, G.S. 1967. A rapid citrate-dithionite extractable iron procedure. Soil Science Society of America Proceedings. Madison, 31:210-211.

HUTTON, J.T. 1977. Titanium And zirconium minerals. In: SOIL SCIENCE SOCIETY OF AMERICA (ed.). Minerals in soil environ ments. Ma.dison.

JACKSON, M.L., S.A. TYLER, A.L. WILLIS, G.A. BORBEAU e R. P. PENNINGTON. 1948. Weathering sequence of clay-size minerals in soils and sediments. The Journal of Physical: and Colloid Chemistry. Washington, D.C., 52(7):1237-1259.

JACKSON, M.L. e G.O. SCHERMAN.1953. Chemical weathering of minerais in soils. Advances in Agronomy. New York, 5:219-318. 
JENNY, H. 194l. Factors of soil formation: a system of quanti tative pedology. New York, McGraw-Hill, 281 p.

KANEHIRO, Y. e G.D. SHERMAN, 1956. Effect of dehydration-rehy dration on cation exchange capacity of Hawaiian soils.Soil Science Society of America Proceedings. Medison, 20 (3):341344 .

KILMER, V.J. and L.T. ALEXANDER. 1949. Methods of making mechanical analysis of soils. Soil Science. Baltimore, 68:1524 .

KING, L.C. 1956. A geomorfologia do Brasil Oriental. Revista. Brasileira de Geografia. Rio de Janeiro, 18(2):147-265.

KUNZE, G.W. 1965. Pretreatment for mineralogical analysis. In: BLACK, C.A. (ed). Methods of soil analysis. Madson.. Wisc. American Society of Agronomy, 574-576. (Agronomy 9).

LEMOS, R.C. e SANTOS, R.D. 1976. Manual de método de trabalho. de campo. Campinas, Sociedade Brasileira de Ciência do So$10,36 p$.

MARCOS, Z.Z. 1971. Morphologic and physical properties of fine-textured Oxisols, State of São Paulo. Columbus, Ohio State University, (ph.D.Thesis).

MEHRA, O.P. e M.L. JACKSON. 1960. Iron oxides removel from soils and clays by a dithionite-citrate system buffered with sodium bicarbonate. In: National Conference on Clays and Clay Mineralis. 7, Proceedings. New York, Pergamon Prẹ, p. $317-327$. 
MCKEAGUE, J.A. e J.H. DAY, 1966. Dithionite and oxalate-extra ctable $\mathrm{Fe}$ and $A l$ as aids in differentiating various classes of soils. Canadian Journal of Soil Science. Ottawa, . 46 : $13-22$.

MCKEAGUE, J.A., J.E. BRYDON e N.M. MILES. 1971. Differenciation of forms of extractable iron and aluminum in soils. Soil Science Society of America Proceedings. Madison, 35: $33-38$.

MILNE, G. 1935. Composite units for the mapping of complex soil associations In: International Congress of Soil Scien ce, 3. Transactions, Oxford. Thomas Murby, v.1 p. 345-347. MILNE, G, V.A. BECKLEY, G.H. GETHIN JONES, W.S. MARTIN, G. GRIFFITH e L.W. RAYMOND. 1935. A provisional soil map of East Africa. In: International Congress of soil Science, 3 . Oxford, Thomas Murby, v:l p.266-270.

MONIZ, A.C. e M.L. JACKSON. 1967. Quantitative mineralogical analysis of Brazilian Soils derived from basic rocks and slate. Nadison, Universitỵ of Wisconsin, 74p. (Wisconsin Soil Science Report, 212 J.

MOORE; T.R. 1973. The Distribution of iron, manganese and alu minium in some soils from North-East Scotland. The Journal. of Soil Science. Oxford, 24(2):162-17.0:

MOTHCI, E.P. 1977. Características, gènese e aptidão àgrícolá de uma sequéncia de solos no Planalto Central Brasileiro. Porto Alegre, Faculdade de Agronomia, Universidade Federal do Rio Grande do Sul. 107p. Tese de Mestrado. 
MULCAHY, M.L. 1960. Laterites and lateritic soils in SouthWest Australia. Journal of Soil Science. Edinburgh, 11:206225.

NYE, P.H. 1954. Some soil-forming processes in the humid tropics. I. A field study of a catena niear Ibadau. Journal of Soil Science. Edinburgh, $\underline{5}: 7-21 .$.

- 1955. Some soil-forming processes in the humid tropics. II. The development of the upper slope member of the catena. Journal of Soil Science. Edinburgh, 6:51-62.

OLLIER, C.D. 1959. A two-cyclo theory of tropical pedology. Journal of Soil Science. Edinburgh, 10:137-148.

PENTEADO, M.M. 1972. Caractẹização geomorfológica da região. de Pirapora, Jequitaí e Várzea da Palma. Apud. RANZANI, G., J.E.S. PESSOTTI e R.J.R. JIMENEZ. 1977. Levantamento semidetalhado dos solos do projeto Jequitaí (MG). CODEVASF CES/ESALQ. Piracicaba. (Mimeografado\}. - e G.RANZANI. 1973. Relatório de viagem ao médio vale do rio São Francisco. Geomorfologia. Piracicaba. 40: $1-44$

PESSOTTI, J.E.S. 1978. Mineralogia dos solos do baixo vale do rio Jequitai - Minas Gerais. Tese de Mestrado não publicado.

PIERANTONI, H. Correlações entre argila e constantes hídricas em Latossolos do sul de Mato Grosso. In: CONGRESSO BRASI LEIRO DE CIENCIA dO SOLO, 13, Vitória. 1971. Rio de Janei-. ro: 19.73, P.22. Resumos: 
RANZANI, G., J.E.S. PESSOTTI e R.J.R. JIMENEZ. 1977 . Levantamento semi-detalhado dos solos do projeto Jequitaí(MG). CO DEVASF-CES/ESALQ. Piracicaba (Mimeografado).

RICHARDS, L.A. 1965. Physical condition of water in soil. In: BLACK, C.A. (ed). Methods of soil analysis. Madison, Wisc, American Society of Agronomy, p128-152. (Agronomy 9).

ROSS.JR., S.J., D.P. FRANSMEIER e C.B. ROTH. 1976 . Mineralogy and chemistry of manganese oxides in some Indiana soils. Soil Science Society of America Journal. Madison, 40: 137143.

RUHE, R.B. 1960. Elements of soil landscape. In: Internatio nal Congress of Soll Science, 7 . Transactions, Madisoni Wisc., International Society of Soil Science, v.4., p.165170 .

SCHWERTMANN, U. 1959. Die Fraktionierte extraktion der freien eisenoxide in boden, ibre mineralogischen formen und ibre entstehungsweisen. Z. Pflanzenernahr Dung. Bodenkunde. Apud. MCKEAGUE, J.A., J.E. Brydọn e N.M. MILES, 1971. Differenti ation of forms of extractable iron and aluminum in soils. Soil Science Society of America Proceedings. Madison, 35 : $33-38$.

SCHWERTMANN, U., W.R. FISCHER E H. PAPENDORF, 1968. The Influ ence of organic compounds on the formation of iron ioxides: In: International Congress of Soil Science, 9. Transactions. Adellaide, V.I, P. 645-655. 
SCHWERTMANN, U. e R.M. TAYLOR. 1977. Iron oxides. In:

SCIENCE SOCIETY DF AMERICA (ed). Minerals in soil environments, Madison.

SHERMAN, G.D. 1949. Factors influencing the development of laterite and lateritic soils in the Hawaiian Islands. Pacific Science. Honolulu, $3: 307-314$.

SHERMAN, G.D. 1952. The genesis and morphology bf alumina-rich laterite clays. In: AMERICAN INSTITUTE OF MINERAL AND METALLURGICAL ENGENEERS. Problems of clay and laterite genesis - Symposium, New York, p154-161.

SHERMAN, G.D. 1957. Formation of gibbsite agregates in Latosols developed on volcanic ash. Science. Washington, D. C. $125: 1243-1244$.

TAMURA, T. e M.L. JACKSON. 1953. Structural and energy relationships in formation of iron and aluminum oxides, hidroxides and silicates. Science. Washington, D.C. 117:381-383.

THORNTHWAITE, C.W. e J.R. MATHER, 1955. Publ. Climatology. ll: $1-104$

VAN RAIJ, B. e M. PEECH. 1972. Eletrochemical properties of some Oxisols and Alfisols of the tropics. Soil Science Society of America Proceedings. Madison, 36: 5̣87-593.

VAN WAMBEKE, A. 1962. Criteria for classifying soils by age. Journal of Soil Science. Edinburgh, 13:124-132.

VETTORI, L. 1969. Métodos de análise de solio.Rio de Janeiro. Equipe de Pedologia e Fertilidade do Solo, 24p. (Boletim Técnico $n^{8} 7$ ): 
A P E N D I C E

Descrịção dos perfís 
Perfil 1

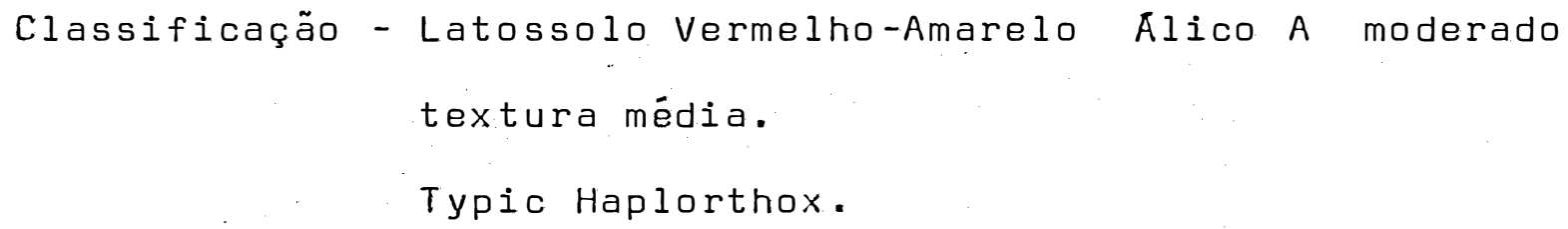

Localização - Estrada Pirapora-Montes Claros, aproximadamente a l km de Guaicuí, pelo lado esquerdo, a 700 metros desta por uma secundária que leva à margem direita do rio São Francisco.

Altitude - 520 metros.

Material originário - Sedimentós areno-argilosos.

Relevo: local - Plano regional - Suave ondulado.

Drenagem - Boa.

Vegetação - Cerrado secundário.

\section{DESCRIÇĂO DO PERFIL}

Al - $0-12 \mathrm{~cm}$, bruno $(7,5$ YR 5/4, úmido) mosqueado bruno-escuro (7,5 YR 4/2) médio e distinto, 40\%; areia franca; fraca média granular; muito friável, não plástico e não pegajoso; raizes fịnas, abundantes, médias a gros 
96.

sas comuns; galerias biológicas menores que $5 \mathrm{~mm}$ abundantes; acumulações de matéria orgánica comuns; poros finos e médios, caóticos descontínuos abundantes; deposição de lomm aproximadamente de areia em superfície; transição ondulada e’ clara.

B21 - 12-32cm, vermelho-amarelado (5 YR 5/6, úmido); areia franca; fraca média prismática que se rompe em blocos subangulares; muito friável, ligeiramente plástico e pegajoso; raízes médias e grossas abundantes; galerias biológicas menores que lomm abundantes, algumas com paredes cerosas; poros médios oblíquos descontínuos abundantes; transição ondulada e gradual.

B22 - 32-92cm, vermelho-amarelado (5 RY 5/6, úmido); franco arenoso; fraca médiablocos subangulares; muito friável, ligeiramente plástico e pegajoso; raízes médias comuns; galerias biológicas menores-que $10 \mathrm{~mm}$ comuns, a lgumas com acumulações de argila cimentando quartzo fino; poros médios verticais e horizontais descontínuos abundantes; transição onduliada e difusa.

B3 - 93-150 $\mathrm{cm}^{+}$, vermeltio-amarelado ( $5 \mathrm{RY} 5 / 6$, úmido) âfranco-argilo-arenoso; fraca irregular em grumos; muito friävel, ligeiramente plástico e ligeiramente pegajo= sos raízies finas poucas; poros médios verticais contí nuos abundantes. 


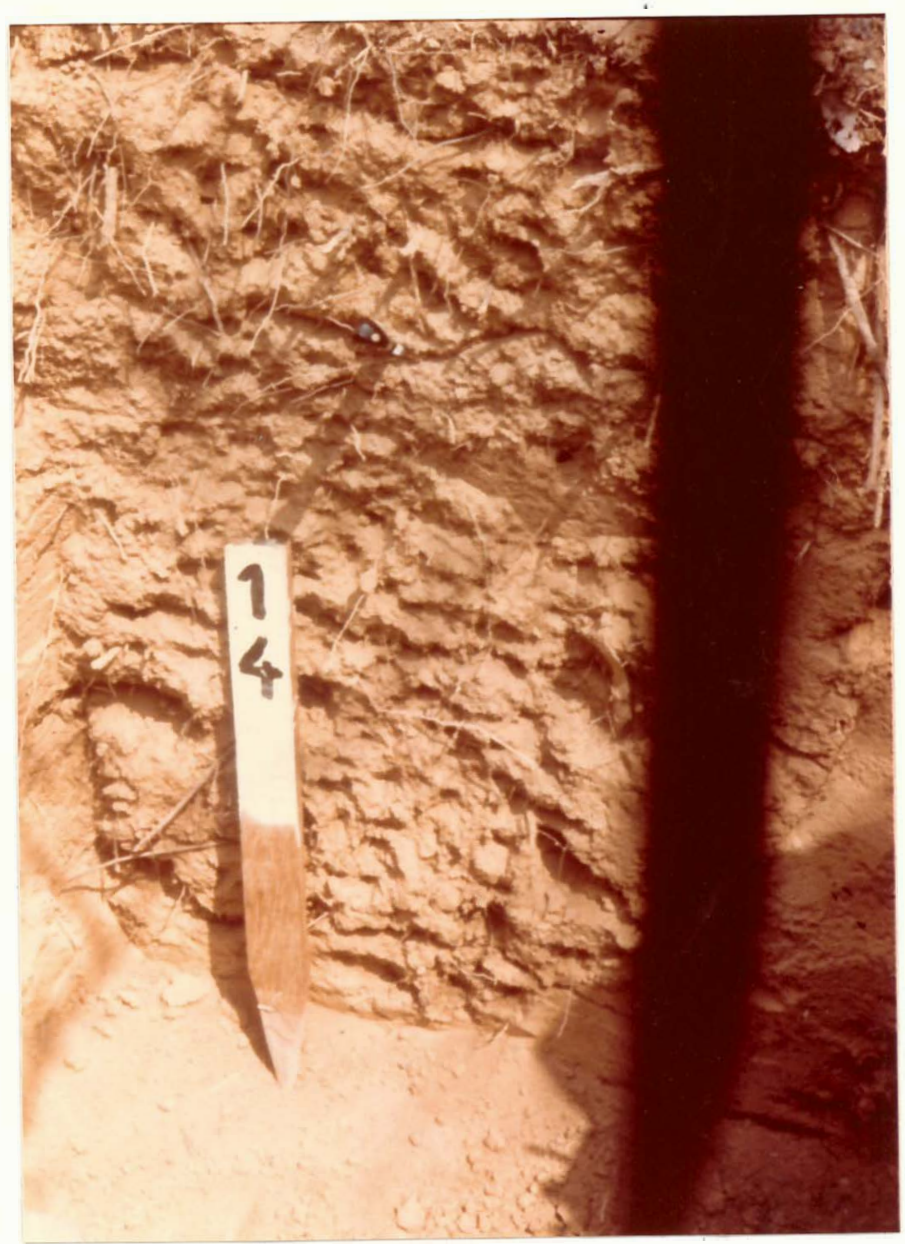

Figura 12. Aspecto do perfil 1. 


\begin{abstract}
Perfil 2
Classificação - Podzólico Vermelho-Amarelo Alico latossólico plíntico A moderado textura médialargilosa. Plinthic Paleustult.
\end{abstract}

Localização - Estrada Pirapora-Montes Claros, aproximadamente a $1 \mathrm{~km}$. de Guaicuí, penetrando-se à esquerda por uma secundária cerca de 2.000 metros.

Altitude - 510 metros.

Material originário - Sedimentos argilo-arenosos retrabalha dos.

Relevo: local - Plano regional - Plano a levemente deprimido.

Drenagem - Boa nos três primeiros horizontes e imperfeita no - Úitimo.

Vegetação - Floresta caducifólia transição a cerrado.

\title{
DESCRIÇAOO DO PERFIL
}

Al - o-8cm, bruno-acinzentado muito escuro (10 YR 3/2, úmì do): franco-arenoso; moderada média a fina flocos subangulares; muito friável, ligeiramente plástico e li 
geiramente pegajoso; raízes muito finas abundantes, mé dias poucas; poros finos caóticos descontínuos abundantes; transição ondulada e clara.

Blt - B-38cm, bruno forte (7,5 YR 5/6, úmido), franco argiloso; moderada grande blocos subangulares; friável. muito plástico e muito pegajoso; raízes finas raras; galerias biológicas menores que lomm comuns; cerosida de pouca; poros finos e médios verticais descontínuos abundantes; acumulação ferruginosa vermelho-amarelado ( 5 YR 5/8) 5\%; transição onidulada e gradual.

IIB22 - 38-100cm, amarelo-avermelhado (7,5 YR 5/8, úmido);mos queado vermelho $(2,5$ YR $4 / 6) 20 \%$, médio irregular dis tinto e abrupto; franco-argiloso; fraca média grande prismática; muito friável, muito plástico e muito pegajoso; raízes muito finas raras; galerias biológicas menores que $5 \mathrm{~mm}$ comuns; poros médios oblíquos descontínuos abundantes; acumulações vermelhas de ferro e argila comuns; acumulações de argila em galerias grañ des cimentando quartzo fino; transição ondulada e gra dual.

IIB3 - 100-140cm, amarelo-avermelhado (7,5 YR 5/6, ümido);mos queado vermelho $(2,5$ YR $4 / 6) 30 \%$ e bruno muito claro acinzentado (10 YR 7/3) 10\%, pequeno a médio diștinto; 
100.

franco-argiloso; fraca média prismática; muito friável, muito plástico e muito pegajoso; raízes finas ra ras; poros finos e médios caóticos abundantes; acumulação de ferro em concreções irregulares menores que $20 \mathrm{~mm}$. 


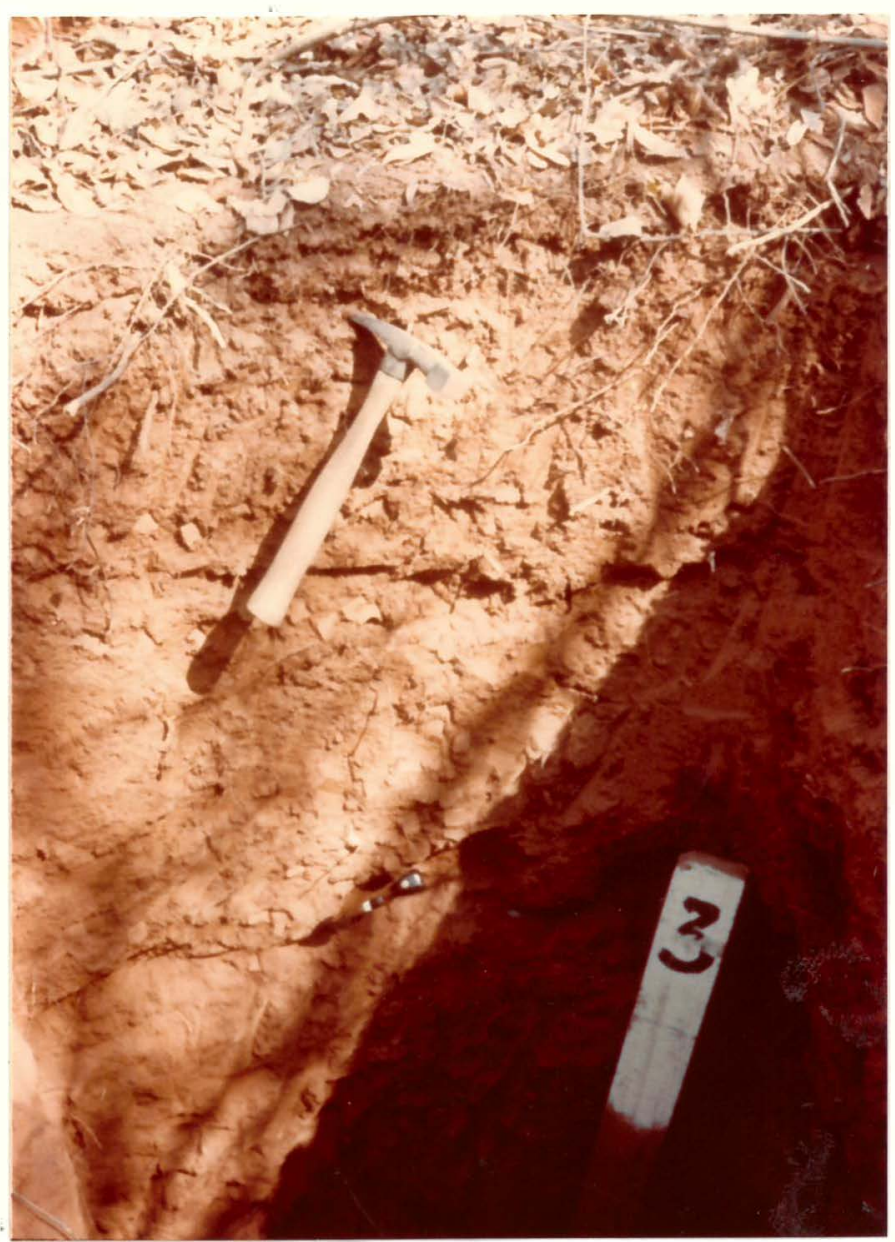

Figura 13. Aspecto do perfil'2. 


\title{
Perfil 3
}

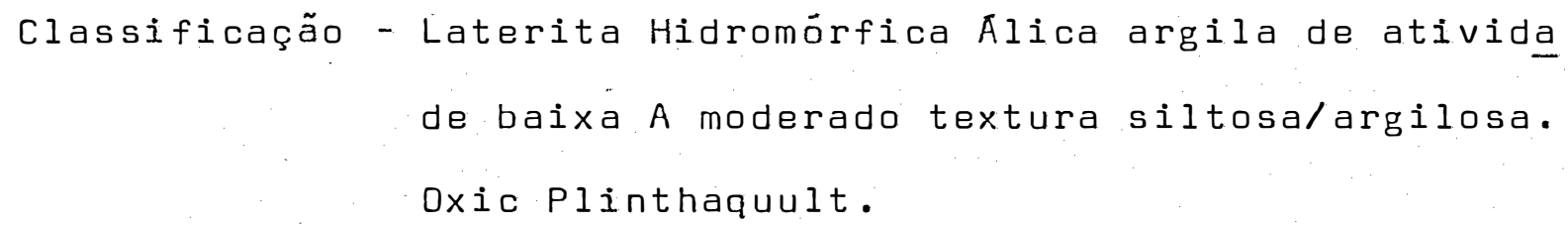

Localização - Estrada Pirápora-Montes Claros, aproximadamente a $1 \mathrm{~km}$ de Guaicuí, penetrando-se à esquerda por uma secundária cerca de 2.000 metros.

\begin{abstract}
Altitude - 450 metros.
\end{abstract}
Material originário - Sedimentos argilosos retrabalhados.

Relevo - local: Plano

regional: Plano, com äreas deprimidas.

Drenagem - Impedida.

Vegetação - Campina de várzea associada a áreas de cerrado ra 10 e de porte baixo.

DESCRIÇÃO OO PERFIL

Al - 0-8cm, bruno-escuro (10 YR 4/3, ümido); franco-argilosiltoso; moderada média a fina blocos subangulares: friável, muito plástico e muito pegajoso; raízes finas 
e muito finas abundantes; galerias biológicas maiores que $10 \mathrm{~mm}$ abundantes; poros médios e finos ciáticos des contínuos abundantes; transição ondulada e clara.

Blt - 8-34cm, bruno-amarelado-claro (10 YR 6/4, úmido); mosqueado vermelho $(2,5$ YR $5 / 8) 15 \%$, pequeno e distinto; franco-argilo-siltoso; forte média a grande blocos subangulares; friável, muito plástico e muito pegajoso; cerosidade fraca pouca em alguns planos; raízes muito finas poucas; galerias biológicas menores que $10 \mathrm{~mm}$ comuns, algumas com preenchimento de argila cimentando areia fina, poros finos caóticos descontínuos abundantes; transição ondulada e clara.

IIB2t - 34-89cm, bruno muito claro (10 YR $7 / 3$, úmido) mosqueado vermelho $(2,5$ YR $5 / 8)$ de acumulaçäo de ferro, $15 \%$, distinto; argilo-siltoso; moderada grande prismátic a que se rompe em média a grande blocos subangulares; fri ável, muito plástico e muito pegajoso; galerias biológicas menores que lomm comuns; poros médios caóticos descontínuos abundantes; transição ondulada e gradual.

IICpl - $89-150 \mathrm{~cm}^{+}$, bruno muito claro (10 YR.7/3, ümido); mosqueado vermelho $(2,5$ YR $5 / 8)$ ferruginoso, $30 \%$, distinto e abrupto; franco-argiloso; moderada grande prismática que se rompe em média blocos subangulares; friável, muito plástico e muito pẹgajoso; poros médios caó 
ticos descontínuos abundantes; acumulações de ferro em áreas irregulares vermelhas; seixos quartiziticos meno res que $20 \mathrm{mmm}$ dispersos no horizonte. 


\section{Perfil 4}

Classificação - Brunizem Avermelhado textura média. Udic Paleustoll.

Localização - Estrada Pirapora-Montes Claros aproximadamente a I km de Guaicuí, pelo lado esquerdo em estrada secundária por 5.500 metros e a 250 metros da margem direita do rio São Francisco.

Altitude - 400 metros.

Material originário - Sedimentos argilo-siltosos fluviais.

Relevo: local - Plano regional - Plano.

Drenagem - Boa.

Vegetação - Floresta ribeirinha.

DESCR IÇÃO DO PERFIL

All - 0-10cm, bruno-acinzentado muito escuro $\{10$ YR 3/2, úmi do): franco-silteso; forte média a fina blocos subangu lares; friável, plástico e pegajoso; raízes grossas e finas abundantes, muito grossas raras; galerias bioló- 
gicas menores que $10 \mathrm{~mm}$ abundantes, algumas preenchidas com material preto $(N 2 /)$; carvões pequenos comuns; transição ondulada e gradual.

Al2 - 10-40cm, bruno-acinzentado muitö escuro (10 YR 3/2, úmido); franco-siltoso; forte.média a grande blocos subangulares; friável, plástico e pegajoso; raízes grossas e finas abundantes; galerias biológichas menores que $10 \mathrm{~mm}$ abundantes, algumas preenchidas com material preto (N 2/) ); poros médios e finos horizontais e oblíquos contínuos abundantes; carvões pequenos raros;tran sição ondulada e gradual.

A2, t - 40-82cm, bruno-escuro (7,5 YR 4/4, úmido); franco-siltoso: moderada média prismática; friável, muito plástí co e muito pegajoso; cerosidade moderada em planos ve $\underline{r}$ ticais e horizontais em películas médias abundantes; ra ízes finas comuns; galerias biológicas menores que $10 \mathrm{~mm}$ comuns; poros médios descontínuos caóticos abundantes: transição ondulada e gradual. 


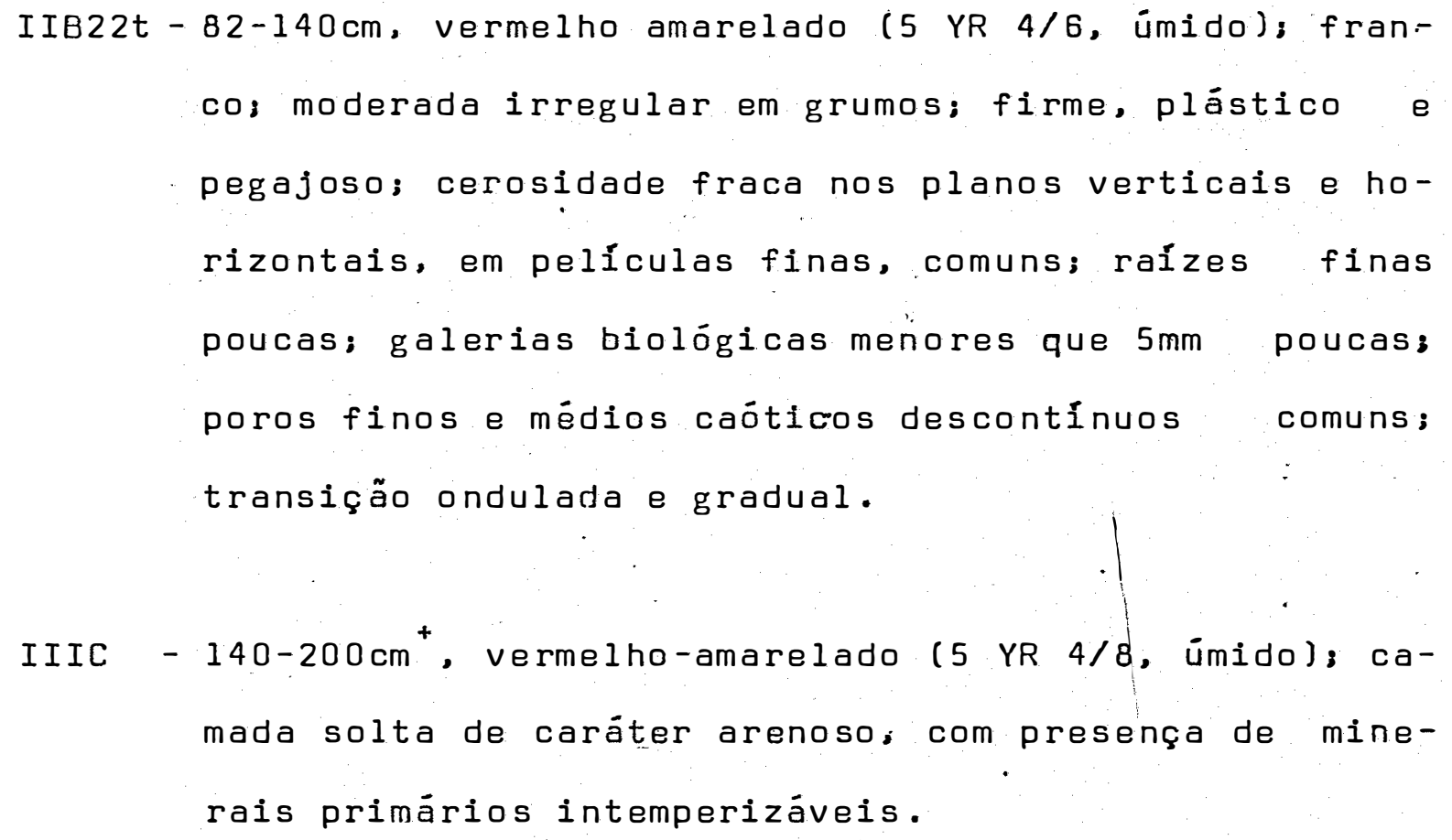

